This document is confidential and is proprietary to the American Chemical Society and its authors. Do not copy or disclose without written permission. If you have received this item in error, notify the sender and delete all copies.

\title{
En Route to Chiral-at-Metal Ruthenium Complexes Containing Tripodal Tetradentate Ligands
}

\begin{tabular}{|r|l|}
\hline Journal: & Organometallics \\
\hline Manuscript ID & om-2018-00180z.R1 \\
\hline Manuscript Type: & Article \\
\hline Date Submitted by the Author: & n/a \\
\hline Complete List of Authors: & $\begin{array}{l}\text { Téllez, Juan; Instituto de Síntesis Química y Catálisis Homogénea } \\
\text { Méndez, Isabel; Instituto de Síntesis Química y Catálisis Homogénea } \\
\text { Viguri, Fernando; Departamento de Química Inorgánica, Instituto } \\
\text { Universitario de Catálisis Ho } \\
\text { Rodríguez, Ricardo; Instituto de Síntesis Química y Catálisis Homogénea, } \\
\text { Lahoz, Fernando; Consejo Superior de Investigaciones Cientificas, Instituto } \\
\text { de Síntesis Química y Catálisis Homogénea - ISQCH } \\
\text { García-Orduña, Pilar; University of Zaragoza-CSIC, Inorganic Chemistry } \\
\text { Carmona, Daniel; Consejo Superior de Investigaciones Científicas, Química } \\
\text { Inorgánica }\end{array}$ \\
\hline \multicolumn{2}{|l}{} \\
\hline
\end{tabular}

\section{SCHOLARONE ${ }^{\text {Tw }}$}

Manuscripts 


\section{En Route to Chiral-at-Metal Ruthenium Complexes Containing}

\section{Tripodal Tetradentate Ligands}

Juan Téllez, Isabel Méndez, Fernando Viguri, * Ricardo Rodríguez, ${ }^{*}$ Fernando J. Lahoz, Pilar García-Orduña, and Daniel Carmona*

Instituto de Síntesis Química y Catálisis Homogénea (ISQCH), CSIC - Universidad de Zaragoza, Departamento de Química Inorgánica, Pedro Cerbuna 12, E-50009

Zaragoza, Spain

For Table of Contents use only

Ruthenium(II) complexes bearing tripodal tetradentate ligands

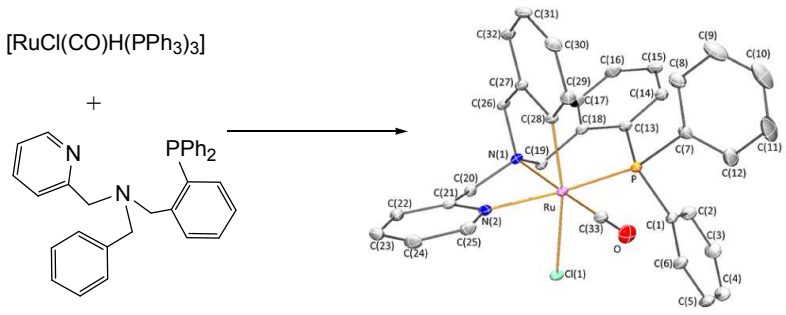

ABSTRACT: Tripodal ligands LH1-LH3 diastereoselectively react with the dimer $\left[\{(\mathrm{Cy}) \mathrm{RuCl}\}_{2}(\mu-\mathrm{Cl})_{2}\right]\left(\mathrm{Cy}=\eta^{6}-p-\mathrm{MeC}_{6} \mathrm{H}_{4} i \mathrm{Pr}\right)$ affording the $p$-cymene compounds $\left[(\mathrm{Cy}) \operatorname{Ru}\left(\kappa^{3} N, N^{\prime}, P-\mathbf{L H}\right)\right]\left[\mathrm{SbF}_{6}\right]_{2}(\mathbf{L H}=\mathbf{L H 1}$ (1), LH2 (2), LH3 (3)) as a racemic mixture of only the $R^{*}{ }_{\mathrm{Ru}}, S^{*}{ }_{\mathrm{N}}$ isomers. Refluxing in MeCN complexes 1-3 gives racemates of a fac isomer of the complexes $\left[\mathrm{Ru}\left(\kappa^{3} N, N^{\prime}, P-\mathbf{L H}\right)(\mathrm{NCMe})_{3}\right]\left[\mathrm{SbF}_{6}\right]_{2}(\mathbf{L H}=$ LH1 (4a), LH2 (5a), LH3 (6a). In refluxing MeOH, isomers 4a-6a evolve to the corresponding mer isomers 4c-6c. Reaction of $\left[\mathrm{RuCl}_{2}\left(\mathrm{PPh}_{3}\right)_{3}\right]$ with $\mathbf{L H 1}$ affords $\left[\mathrm{RuCl}_{2}\left(\mathrm{PPh}_{3}\right)\left(\kappa^{3} N, N^{\prime}, P\right.\right.$-LH1)] (7) as a racemic mixture of only one pair of stereoisomers. $\left[\mathrm{RuClH}(\mathrm{CO})\left(\mathrm{PPh}_{3}\right)_{3}\right]$ reacts with $\mathbf{L H}$ to give $\left[\mathrm{RuH}(\mathrm{CO})\left(\mathrm{PPh}_{3}\right)\left(\kappa^{3} N, N^{\prime}, P\right.\right.$ - 
LH)]Cl $(\mathbf{L H}=\mathbf{L H 1}(\mathbf{8}), \mathbf{L H 2}(\mathbf{9}), \mathbf{L H 3}(\mathbf{1 0}))$ in which the LH ligands present a $\kappa^{3}$ coordination mode. Complexes 8-10 were isolated as a mixture of only two diastereomers as pairs of enantiomers. Refluxing in 2-ethoxyethanol suspensions of mixtures of isomers of the complexes 8-10 afforded the corresponding metalated complexes $\left[\mathrm{RuCl}(\mathrm{CO})\left(\kappa^{4} C, N, N^{\prime}, P-\mathbf{L}\right)\right](\mathbf{L}=\mathbf{L 1}(\mathbf{1 1}), \mathbf{L 2}(\mathbf{1 2}), \mathbf{L 3}(\mathbf{1 3}))$. Only one stereoisomer was detected for complexes $\mathbf{1 1}$ and $\mathbf{1 3}$ but metalation at the C-2 or C-6 carbons gave a mixture of two isomers for complex 12. The new complexes have been characterized by analytical and spectroscopic means and by the determination of the crystal structures of the complexes 1, 2, 5c, 10a, 11a, 12a,b and 13a by X-ray diffractometry. 


\section{INTRODUCTION}

Typically, an asymmetric metallic catalyst consists of a metal surrounded by a chiral ligand together with some ancillary achiral ligands. Activation of prochiral substrates takes place through coordination to the metal and during the catalytic process chirality is transferred from the catalyst to the newly formed stereogenic centers. ${ }^{1}$ According to this path, it might be argued that chiral-at-metal catalysts would be well suited to transfer chirality efficiently due to the close proximity between the source and the receptor of chirality. ${ }^{2}$

However, examples of chiral catalysts in which the source of chirality was unequivocally the stereogenic metal center are scarce. Most probably, this scantiness is due to the demanding requirements of resolution, configurational stability and labile coordination sites that make the design of these peculiar species a challenging task. Indeed, efficient chiral-at-metal catalysts bearing solely achiral ligands have been developed only recently. The contribution of Meggers's group to this area is especially relevant. $^{2 \mathrm{a}, 3}$ The new class of catalysts prepared by this group mostly consist of cationic octahedral rhodium(III), iridium(III) or, in a lesser extent, ruthenium(II) complexes containing two cyclometalated 5-tert-butyl-2-phenylbenzoxazoles, 5-tert-butyl-2phenylbenzothiazoles or $N$-(2-pyridyl)- $N$-heterocyclic carbene and two labile acetonitrile molecules. Chirality results from the right-handed $(\Delta)$ or left-handed $(\Lambda)$ propeller defined by the two cyclometalated ligands. The resulting compounds are efficient asymmetric catalysts for a variety of transformations including visible-lightactivated photoredox reactions. ${ }^{2 \mathrm{a}, 3}$

In this regard, we have recently shown that, in octahedral rhodium(III) and iridium(III) complexes, tripodal ligands (LH) of the type depicted in Chart 1 are able to act as tetradentate ligands through the aminic and pyridinic nitrogen atoms, the 
phosphorus and one of the aromatic carbon atoms of the benzyl substituent. Remarkably, when in octahedral complexes, tripodal ligands display a $\kappa^{4} C, N, N^{\prime}, P$ coordination mode, the presence of four distinct ligating atoms guarantees the stereogenicity at the metal as well as the mutual cis disposition of the two remaining coordination sites, which are potentially available for catalytic transformations.

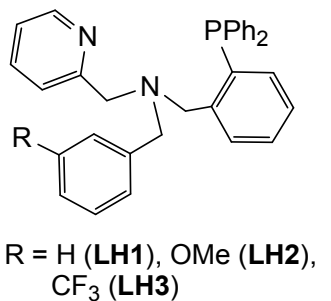
$\mathrm{CF}_{3}$ (LH3)

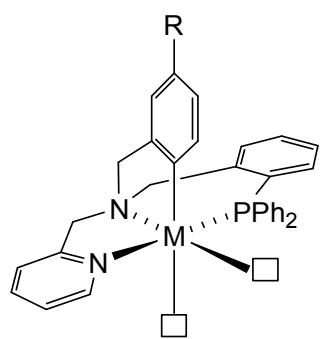

1
1
1
1
1
1
1
1
1 $M=R h, I r$

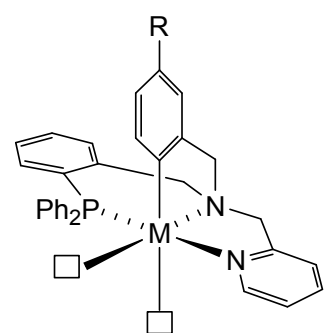

Scheme 1. Octahedral rhodium and iridium complexes with tripodal tetradentate ligands showing a ${ }^{4} C, N, N^{\prime}, P$ coordination mode.

It is worthy of note that steric and electronic constraints within this type of ligands controls the stereochemistry of the complexes. Thus, experimental studies and DFT calculations showed that the isomer in which the phosphorus atom is trans to the pyridinic nitrogen (see Scheme 1) is the most stable and, indeed, it was the only detected and isolated. ${ }^{4}$ On the other hand, starting from the aminic LH ligands, the compounds will be obtained as racemic mixtures containing the metal and the aminic nitrogen as stereogenic centers. Notably, the sign of the chirality adopted by the metal predetermines the configuration at the aminic nitrogen ${ }^{5}$ and it has been shown that the coordination features of the tetradentate ligands confer a high thermal and configurational stability to the $4 \mathrm{~d}$ and $5 \mathrm{~d}$ metal complexes. ${ }^{4}$

We have recently resolved the dichlorido rhodium racemates $\left[\mathrm{RhCl}_{2}\left(\kappa^{4} C, N, N^{\prime}, P-\mathbf{L 1}\right)\right]$ and applied derived enantiopure solvates $\left[\mathrm{RhCl}\left(\kappa^{4} C, N, N^{\prime}, P-\mathbf{L 1}\right)(\mathrm{Solv})\right]^{+} \quad\left(\mathrm{Solv}=\mathrm{H}_{2} \mathrm{O}, \mathrm{MeCN}\right)$ or $\quad\left[\mathrm{Rh}\left(\kappa^{4} C, N, N^{\prime}, P-\mathbf{L 1}\right)\right.$ $\left.(\mathrm{NCMe})_{2}\right]^{2+}$ as catalyst precursors in the Diels-Alder reaction between methacrolein and cyclopentadiene. Enantiomeric ratios of up to $>99 / 1$ were obtained. ${ }^{6}$ In this regard, it is 
pertinent to point out that the phenyl groups of the phosphano arm of the ligand L1 shield one of the faces of the coordination plane defined by the metal and the two vacant sites. However, the other face of this plane remains essentially clear. This property, that is a general feature for this type of complexes, ${ }^{4,6}$ is on the basis of the high enantioselectivity achieved and, hence, the fruitful application of this type of catalysts to related enantioselective transformations may be anticipated.

Taken into account all these considerations, here we present our attempts to prepare octahedral ruthenium(II) complexes bearing the tripodal tetradentate ligands $\mathbf{L H}$ (Chart 1) displaying a $\kappa^{4} C, N, N^{\prime}, P$ coordination mode. Their optical resolution and catalytic applications will be reported in due course. 


\section{RESULTS AND DISCUSSION}

The ligands LH1-LH3 (Chart 1) were prepared as previously reported. ${ }^{\text {4a }}$ The synthesis of ruthenium complexes was attempted starting from the $p$-cymene dimer $\left[\{(\mathrm{Cy}) \mathrm{RuCl}\}_{2}(\mu-\mathrm{Cl})_{2}\right] \quad\left(\mathrm{Cy}=\eta^{6}-p-\mathrm{MeC}_{6} \mathrm{H}_{4} i \mathrm{Pr}\right)^{7}$ as well as from the monomers $\left[\mathrm{RuCl}_{2}\left(\mathrm{PPh}_{3}\right)_{3}\right]^{8}$ and $\left[\mathrm{RuClH}(\mathrm{CO})\left(\mathrm{PPh}_{3}\right)_{3}\right] .{ }^{9}$

Reactions starting from $\left[\{(\mathbf{C y}) \mathbf{R u C l}\}_{2}(\mu-\mathbf{C l})_{2}\right]$. Treatment of acetone solutions of the dimer $\left[\{(\mathrm{Cy}) \mathrm{RuCl}\}_{2}(\mu-\mathrm{Cl})_{2}\right]$ with $\mathrm{AgSbF}_{6}$, removal of the $\mathrm{AgCl}$ formed and subsequent addition of the corresponding ligand $\mathbf{L H}$ afforded complexes of formula $\left[(\mathrm{Cy}) \mathrm{Ru}\left(\kappa^{3} N, N^{\prime}, P-\mathbf{L H}\right)\right]\left[\mathrm{SbF}_{6}\right]_{2}(\mathbf{L H}=\mathbf{L H 1}(\mathbf{1}), \mathbf{L H 2}(\mathbf{2}), \mathbf{L H 3}(\mathbf{3}))$ in $81-88 \%$ yield (Scheme 2).

$1 / 2$

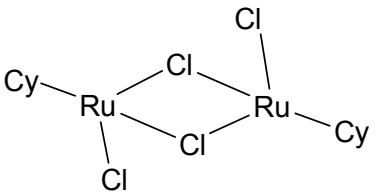



$\mathrm{Cy}=\eta^{6}-p-\mathrm{MeC}_{6} \mathrm{H}_{4} i \operatorname{Pr}$ (p-cymene)
1) $2 \mathrm{AgSbF}_{6}$, acetone, $4 \mathrm{~h}, \mathrm{RT}$ $-2 \mathrm{AgCl}$

2) $\mathrm{LH}, 1 \mathrm{~h}$

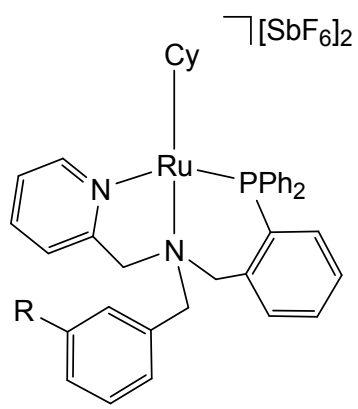

$\mathrm{R}=\mathrm{H}(\mathbf{1}), 85 \%$; OMe (2), $88 \%$; $\mathrm{CF}_{3}$ (3), $81 \%$

Scheme 2. Synthesis of complexes 1-3.

Scheme 3 shows the two diastereomers as pairs of enantiomers of compounds 1-3 that could form in the reaction. The NMR spectra of the isolated solids consist of only one set of sharp signals from RT to $193 \mathrm{~K}$. Therefore, we propose that the formation of these complexes is completely diastereoselective.

The compounds were characterized by analytical and spectroscopic methods (see Experimental) and by the X-ray determination of the crystal structures of complexes 1 and 2. The ${ }^{31} \mathrm{P}\left\{{ }^{1} \mathrm{H}\right\}$ NMR spectra of the isolated isomers consists of one singlet near to $40 \mathrm{ppm}$. The three methylene groups of protons are diastereotopic. The value of the 
$J(\mathrm{PH})$ coupling constant together with COSY, HSQC and HMBC experiments permit the assignment of these protons which have been labeled as $\mathrm{CH}_{2}(\mathrm{Py}), \mathrm{CH}_{2}(\mathrm{Ph})$ and

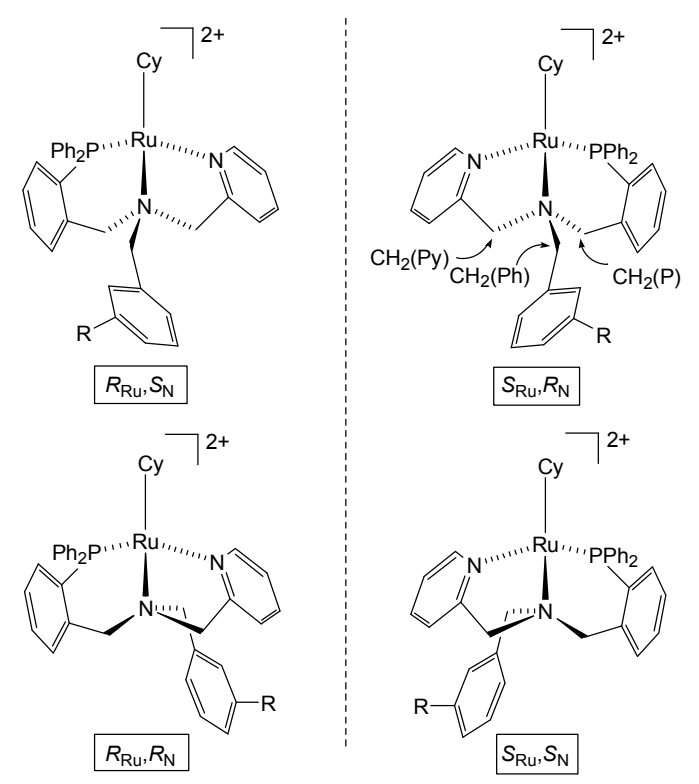

Scheme 3. Isomers of the complexes $\left[(\mathrm{Cy}) \mathrm{Ru}\left(\mathrm{K}^{3} N, N^{\prime}, P-\mathrm{LH}\right)\right]^{2+}(1-3)$.

$\mathrm{CH}_{2}(\mathrm{P})$ (see Scheme 3). One of the $\mathrm{CH}_{2}(\mathrm{Ph})$ methylene protons shows NOE cross peaks with the protons of one of the methyl groups of the isopropyl substituent of the cymene ligand. However, no NOE interaction has been observed between the $\mathrm{CH}_{2}(\mathrm{P})$ methylene protons and any of the $p$-cymene protons. These NOE data are only compatible with the pair of enantiomers $R^{*}{ }_{\mathrm{Ru}}, S^{*}{ }_{\mathrm{N}}{ }^{10}$

Single crystals of $\mathbf{1}$ and $\mathbf{2}$, suitable for X-ray analysis, were obtained from $\mathrm{CH}_{2} \mathrm{Cl}_{2} /$ pentane solutions. As at a molecular level both structures present similar parameters we will discuss here only the structural features of complex 1. For the structural data of complex 2 , see SI. The complex crystallizes in the $P \overline{1}$ centrosymmetric space group and, therefore, a pair of enantiomers, specifically the $R_{\mathrm{Ru}}, S_{\mathrm{N}}$ and $S_{\mathrm{Ru}}, R_{\mathrm{N}}$ isomers ${ }^{10}$ (see Scheme 3), is present in its unit cell. These absolute configurations correspond to those found spectroscopically for the isolated solid. A view of the structure of the cation of $\left(S_{\mathrm{Ru}}, R_{\mathrm{N}}\right)-\mathbf{1}$ is depicted in Figure 1 and relevant characteristics of the metal coordination sphere are summarized in Table 1. 


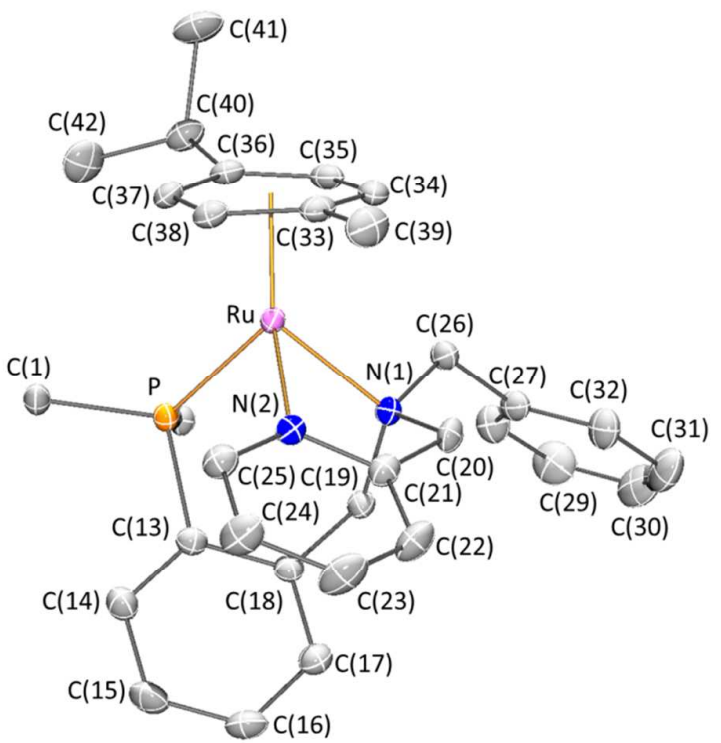

Figure 1. Molecular structure of the cation of the $\left(S_{\mathrm{Ru}}, R_{\mathrm{N}}\right)-1$ isomer. For clarity, hydrogen atoms have been omitted and only the ipso carbon atoms of $\mathrm{PPh}_{2}$ group have been included.

\section{Table 1. Selected Bonds Lengths $(\AA)$ and Angles $\left({ }^{\circ}\right)$ for the Complex $\left(S_{\mathrm{Ru}}, R_{\mathrm{N}}\right)-1$}

\begin{tabular}{|l|l|l|l|}
\hline Ru-P & $2.3503(6)$ & $\mathrm{P}-\mathrm{Ru}-\mathrm{N}(2)$ & $90.34(5)$ \\
\hline $\mathrm{Ru}-\mathrm{N}(1)$ & $2.2144(17)$ & $\mathrm{P}-\mathrm{Ru}-\mathrm{Ct}$ & $132.14(1)$ \\
\hline $\mathrm{Ru}-\mathrm{N}(2)$ & $2.0855(17)$ & $\mathrm{N}(1)-\mathrm{Ru}-\mathrm{N}(2)$ & $76.19(7)$ \\
\hline $\mathrm{Ru}-\mathrm{Ct} \mathrm{t}^{\mathrm{a}}$ & $1.7712(1)$ & $\mathrm{N}(1)-\mathrm{Ru}-\mathrm{Ct}$ & $130.94(1)$ \\
\hline $\mathrm{P}-\mathrm{Ru}-\mathrm{N}(1)$ & $87.03(5)$ & $\mathrm{N}(2)-\mathrm{Ru}-\mathrm{Ct}$ & $122.54(1)$ \\
\hline
\end{tabular}

The ruthenium is pseudo-tetrahedral being coordinated to an $\eta^{6}$-Cy ring and to the phosphorus, aminic nitrogen and pyridinic nitrogen of the ligand LH1. The axis of the Cy ligand is roughly parallel to the vector connecting $\mathrm{P}$ and $\mathrm{N}(2)$, avoiding the steric effects of the $\mathrm{CH}_{2} \mathrm{Ph}$ fragment bound to $\mathrm{N}(1)$. Ruthenium-nitrogen bond lengths are dissimilar, with an elongation of $\mathrm{Ru}-\mathrm{N}(1)$ (aminic nitrogen) bond length, compared to $\mathrm{Ru}-\mathrm{N}(2)$ (pyridinic nitrogen) $(\Delta(\mathrm{Ru}-\mathrm{N}): 0.129(2) \AA)$ slightly longer than that observed in the related complex $\left[\mathrm{RhCl}_{3}\left(\kappa^{3} N, N^{\prime}, P-\mathbf{L 1}\right)\right]$ complex $(\Delta(\mathrm{Rh}-\mathrm{N}): 0.112(2) \AA)^{4 a}$

When acetonitrile solutions of the complexes 1-3 were heated at $65^{\circ} \mathrm{C}$ for $48 \mathrm{~h}$, the Cy ligand was removed and complexes of formula $\left[\mathrm{Ru}\left(\kappa^{3} N, N^{\prime}, P-\mathbf{L H}\right)(\mathrm{NCMe})_{3}\right]\left[\mathrm{SbF}_{6}\right]_{2}$ $($ LH = LH1 (4), LH2 (5), LH3 (6)) were recovered from the reaction medium. 
In these complexes, the metal and the aminic nitrogen are stereogenic centers. All the possible isomers of complexes 4-6 -two enantiomeric pairs of $f a c$ and an enantiomeric pair of mer isomers- are depicted in Scheme 4 labeled with their corresponding stereochemical descriptors. ${ }^{10 \mathrm{a}, \mathrm{b}, 11}$
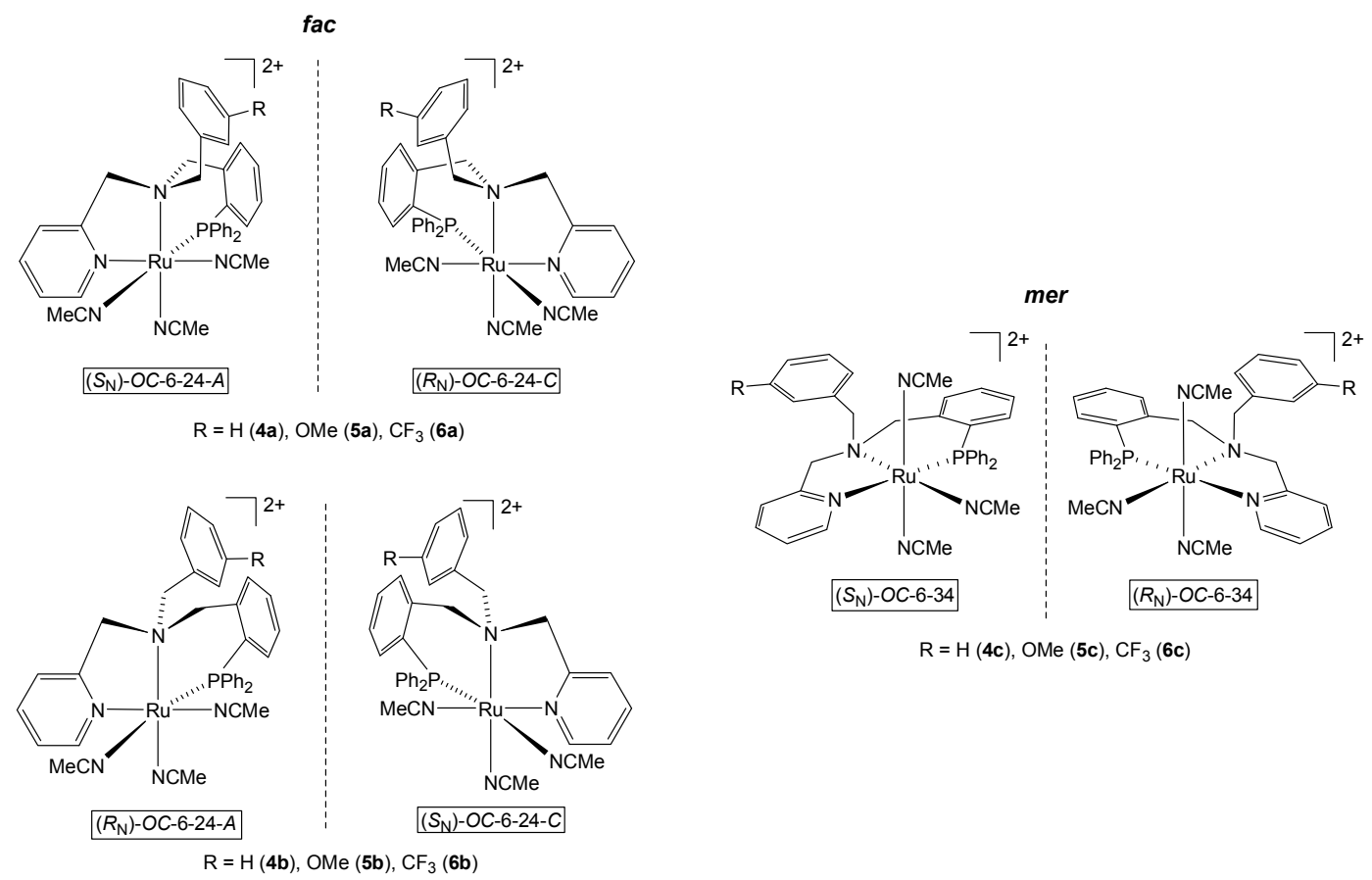

Scheme 4. Isomers of the complexes $\left[\mathrm{Ru}\left(\mathrm{K}^{3} N^{\prime}, N^{\prime}, P-\mathrm{LH}\right)(\mathrm{NCMe})_{3}\right]^{2+}(4-6)$.

Complexes 4-6 were characterized by analytical and spectroscopic means (see Experimental). Assignment of the NMR signals was accomplished by two-dimensional homonuclear and heteronuclear correlations. At room temperature, the ${ }^{1} \mathrm{H}$ and ${ }^{31} \mathrm{P}$ NMR spectra consist of only one set of sharp signals. Besides the three methylene groups of diastereotopic protons, the ${ }^{1} \mathrm{H}$ NMR spectra show three singlets around $2.5 \mathrm{ppm}$, attributed to three inequivalent $\mathrm{NCMe}$ groups, together with a deshielded doublet centered about $8.45 \mathrm{ppm}$ assigned to the proton in the 6-position of the pyridine moiety (6-CH(Py)). Interestingly, whereas the latter shows no coupling to the phosphorus, one of the NCMe nitrile carbon atoms presents a $J(\mathrm{CP})$ coupling constant of around 14.5 $\mathrm{Hz}$, as expected for a trans disposition between the $\mathrm{NCMe}$ and $\mathrm{PPh}_{2}$ fragments. 
Inspection of molecular models indicates that in the $f a c$ isomers $\mathbf{4 b} \mathbf{b}-\mathbf{6 b}$ there is steric hindrance between the benzyl and two phosphine phenyls substituents of the ligand $\mathbf{L}$ (Scheme 4). Taking into account this observation, the NMR data suggest that the isolated solids are the $f a c$ isomers $\mathbf{4 a - 4 b .}$

At $193 \mathrm{~K}$, the ${ }^{1} \mathrm{H}$ and ${ }^{31} \mathrm{P}$ NMR spectra of the isolated solids showed two set of signals. In particular, at this temperature, the ${ }^{31} \mathrm{P}$ NMR spectra consist of two singlets at about 53 and 51-52 ppm in about 87/13 molar ratio, respectively, which coalesce to one unique singlet by heating the sample. The coalescence of these two sets of NMR signals under soft experimental conditions can be accounted for by assuming an interchange between two conformers of isomers 4a-6a. In fact, DFT studies on the related isoelectronic rhodium(III) complexes $\left[\mathrm{RhCl}_{3}\left(\kappa^{3} N, N^{\prime}, P\right.\right.$-L1) $]$ identified two confomers for the corresponding a isomers depending on the conformation of the six-membered Rh-P-C-C-C-N ring (see Scheme 4). ${ }^{4 a}$

Refluxing in methanol for $48 \mathrm{~h}$ complexes 4-6, new species form according to NMR measurements. Conversion was complete for complexes $\mathbf{4}$ and $\mathbf{5}$ but only $40 \%$ of conversion was measured for complex 6 . In the ${ }^{13} \mathrm{C}$ NMR spectra of the new species, no $J(\mathrm{PC})$ coupling was observed for any of the three nitrile carbons present in the molecules. In their ${ }^{1} \mathrm{H}$ NMR spectra, the signal corresponding to the $6-\mathrm{CH}(\mathrm{Py})$ proton appears as a multiplet derived from $J(\mathrm{HH})$ a $J(\mathrm{PH})$ couplings as it has been elucidated from the ${ }^{1} \mathrm{H}\left\{{ }^{31} \mathrm{P}\right\}$ NMR spectra. These spectroscopic data point to structures in which the pyridine and $\mathrm{PPh}_{2}$ arms of the $\mathbf{L H}$ ligand are located mutually trans.

To unequivocally establish the structure of the new species, the crystal structure of the compound 5c was determined by X-ray diffraction means. Crystals suitable for Xray diffraction studies were grown from $\mathrm{CH}_{2} \mathrm{Cl}_{2} / \mathrm{Et}_{2} \mathrm{O}$ solutions of the complex. The molecular structure (Figure 2) shows that the ligand LH2 binds meridionally to the 
ruthenium center in a $\left(\kappa^{3} N, N^{\prime}, P\right)$ fashion. The complex crystallizes in the $P \overline{1}$ centrosymmetric space group and the two enantiomers are present in the unit cell. Inspection of intermolecular interactions evidences the overlap between methyl and benzyl groups of methoxybenzyl fragments of two antipodes as well as the presence of weak $\mathrm{C}-\mathrm{H} \cdots \mathrm{O}$ interactions (see SI).

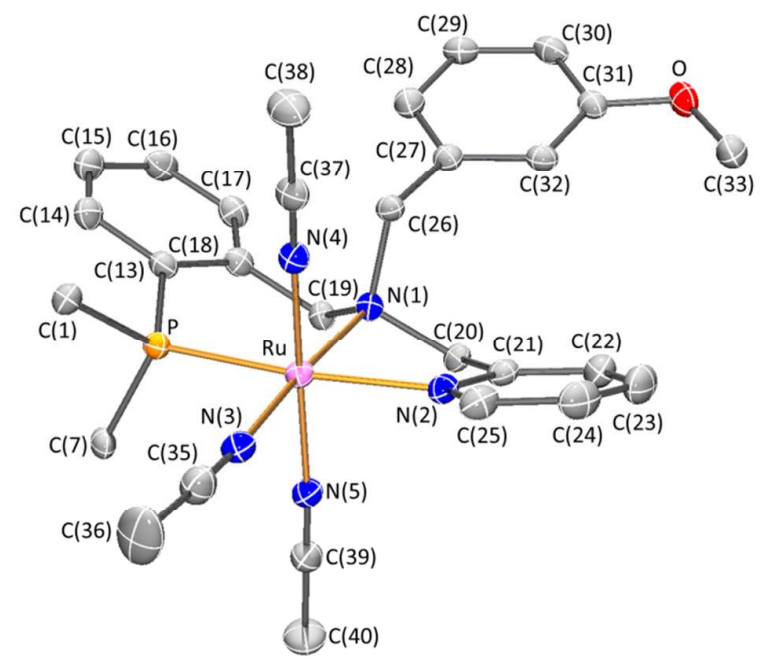

Figure 2. Molecular structure of the cation of the $\left(\left(R_{N}\right)-O C-6-34\right)-5 \mathrm{c}$ isomer. For clarity, hydrogen atoms have been omitted and only the ipso carbons of the $\mathrm{PPh}_{2}$ group are shown.

Table 2 collects some structural parameters of the metal coordination sphere. The pseudooctahedral geometry together with the presence of non-bulky linear acetonitrile groups induce a significantly smaller ring puckering amplitude for the Ru-P-C-C-C-N six membered metallacycle, compared to that observed in complex 1 (see SI). The $\mathrm{Ru}-\mathrm{NCMe}$ bond lengths are similar, ranging from 2.033(3) $\AA$ for the $\mathrm{Ru}-\mathrm{N}(3)$ bond trans to the aminic nitrogen, to 2.024(3) and 2.020(3) $\AA$ for the $\mathrm{Ru}-\mathrm{N}(4)$ and $\mathrm{Ru}-\mathrm{N}(5)$ bonds which are mutually trans.

Thus, the new species is the $m e r-\mathbf{5 c}$ and, from the similarity of the analytical and spectroscopic data, we propose that the same meridional isomers, mer-4c and mer-6c (see Scheme 4), were isolated working with the LH1 and LH3 ligands, respectively. 
Table 2. Selected Bonds Lengths $(\AA)$ and Angles $\left(^{\circ}\right)$ for the Complex 5c

\begin{tabular}{|c|c|c|c|}
\hline Ru-P & $2.2817(10)$ & $\mathrm{N}(1)-\mathrm{Ru}-\mathrm{N}(2)$ & 78.84(11) \\
\hline Ru-N(1) & $2.153(3)$ & $\mathrm{N}(1)-\mathrm{Ru}-\mathrm{N}(3)$ & $175.66(12)$ \\
\hline Ru-N(2) & $2.120(3)$ & $\mathrm{N}(1)-\mathrm{Ru}-\mathrm{N}(4)$ & $94.54(11)$ \\
\hline Ru-N(3) & $2.033(3)$ & $\mathrm{N}(1)-\mathrm{Ru}-\mathrm{N}(5)$ & $88.90(12)$ \\
\hline Ru-N(4) & $2.020(3)$ & $\mathrm{N}(2)-\mathrm{Ru}-\mathrm{N}(3)$ & $96.85(12)$ \\
\hline Ru-N(5) & $2.024(3)$ & $\mathrm{N}(2)-\mathrm{Ru}-\mathrm{N}(4)$ & $86.72(12)$ \\
\hline P-Ru-N(1) & 94.09(8) & $\mathrm{N}(2)-\mathrm{Ru}-\mathrm{N}(5)$ & $91.05(12)$ \\
\hline P-Ru-N(2) & 172.71(9) & $\mathrm{N}(3)-\mathrm{Ru}-\mathrm{N}(4)$ & $85.68(12)$ \\
\hline P-Ru-N(3) & $90.24(9)$ & $\mathrm{N}(3)-\mathrm{Ru}-\mathrm{N}(5)$ & $90.67(12)$ \\
\hline P-Ru-N(4) & $92.14(9)$ & $\mathrm{N}(4)-\mathrm{Ru}-\mathrm{N}(5)$ & $175.46(12)$ \\
\hline P-Ru-N(5) & $90.57(9)$ & & \\
\hline
\end{tabular}

In summary, reaction of complexes 1-3 in refluxing acetonitrile gives rise to the $f a c$ isomers 4a-6a. In refluxing methanol, these compounds evolve to the mer isomers $\mathbf{4 c}$, 5c and $\mathbf{6 c}(40 \%$ conversion for complex $\mathbf{6}$ after $48 \mathrm{~h}$ of treatment, Scheme 5).
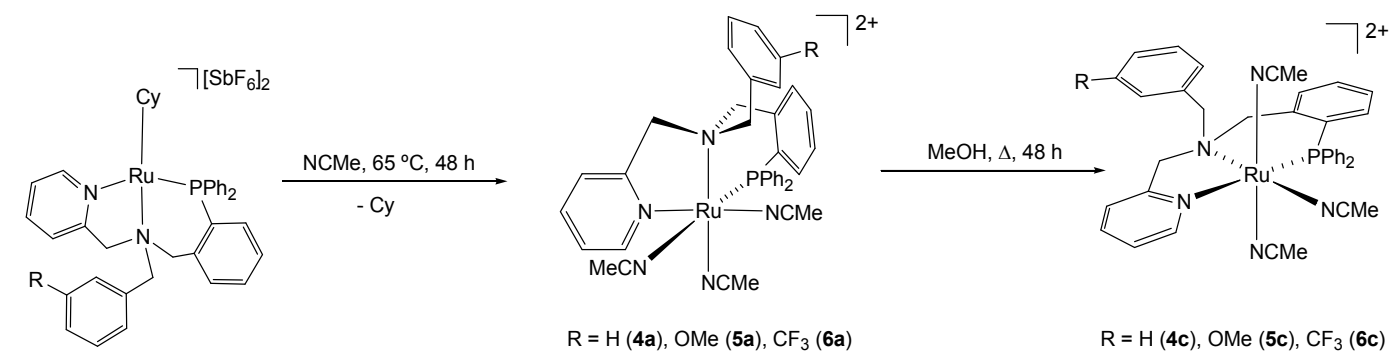

$\mathrm{R}=\mathrm{H}(1), \mathrm{OMe}(2), \mathrm{CF}_{3}(3)$

Scheme 5. Synthesis of the fac and mer isomers of the complexes 4-6. Only one enantiomer of each pair is shown.

All attempts of metalation of the benzylic arm of the ligands $\mathbf{L H}$ in complexes 4-6 have been unsuccessful. Thus, no orthometalation products were isolated when the complexes were refluxed in $\mathrm{MeOH}$ or $\mathrm{EtOH}$ in the presence of various relative amounts of $\mathrm{NaAcO}$ or lithium trifluoroacetate (3-5 equiv.) during several hours (up to 2-3 days). Untreatable mixtures of uncharacterized compounds, some of them containing coordinated acetate or trifluoroacetate ligands, were obtained. Heating ethanolic solutions of the starting compounds at higher temperatures $\left(100-120^{\circ} \mathrm{C}\right)$ in sealed tubes mostly led to decomposition.

Reactions starting from $\left[\mathbf{R u C l}_{\mathbf{2}}\left(\mathbf{P P h}_{\mathbf{3}}\right)_{3}\right]$. Reaction of $\left[\mathrm{RuCl}_{2}\left(\mathrm{PPh}_{3}\right)_{3}\right]$ with $\mathbf{L H 1}$ in refluxing tert-butanol afforded $\left[\mathrm{RuCl}_{2}\left(\mathrm{PPh}_{3}\right)\left(\kappa^{3} N, N^{\prime}, P-\mathbf{L H 1}\right)\right]$ (7) in $97 \%$ yield 
(Scheme 6). The NMR spectra of the isolated solid consist of only one set of sharp signals from RT to $193 \mathrm{~K}$. Therefore, we propose that the formation of this complex is completely diastereoselective. The ${ }^{31} \mathrm{P}\left\{{ }^{1} \mathrm{H}\right\}$ NMR spectrum of 7 consist of two doublets centered at 43.34 and $42.27 \mathrm{ppm}$ with a $J(\mathrm{PP}$ ') coupling constant of $30.7 \mathrm{~Hz}$ attributed to the $\mathrm{PPh}_{3}$ ligand and to the diphenylphosphino moiety of the LH1 ligand, respectively. The pattern of $J(\mathrm{HP})$ and $J(\mathrm{CP})$ couplings encountered for 7 (see Experimental) is in agreement with the structure of the pair of enantiomers $\left(S_{\mathrm{N}}\right)-O C-6-14 /\left(R_{\mathrm{N}}\right)-O C-6-14$ depicted in Scheme 6.
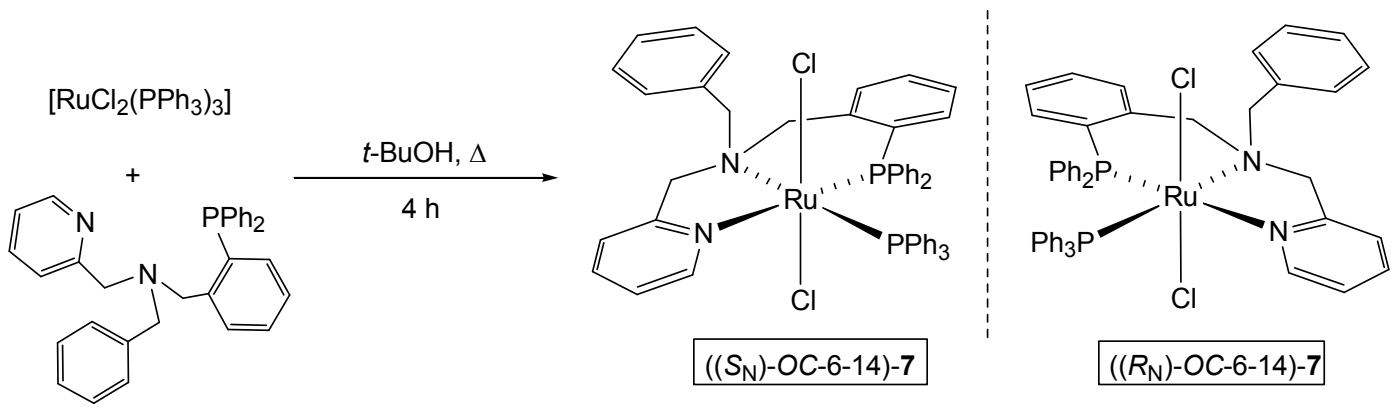

Yield: $97 \%$

Scheme 6. Synthesis of complex 7.

When a sample of complex 7 was refluxed in 2-ethoxyethanol for 2 days in the presence of 4 equiv of $\mathrm{NaAcO}$ a small portion (about $9 \%$ yield) of the metalated complex $\left[\mathrm{RuCl}(\mathrm{CO})\left(\kappa^{4} \mathrm{C}, N, N^{\prime}, P-\mathbf{L 1}\right)\right](\mathbf{1 1})$ was obtained. For an improved synthesis of 11 and its characterization see below.

Reactions starting from $\left[\mathbf{R u C l H}(\mathbf{C O})\left(\mathbf{P P h}_{3}\right)_{3}\right]$. A $1 / 1$ mixture of $\left[\mathrm{RuClH}(\mathrm{CO})\left(\mathrm{PPh}_{3}\right)_{3}\right]$ and LH was suspended in ethanol and refluxed overnight to give, in $79-86 \%$ yield, the corresponding complex of formula $\left[\mathrm{RuH}(\mathrm{CO})\left(\mathrm{PPh}_{3}\right)\left(\kappa^{3} N, N^{\prime}, P-\mathbf{L H}\right)\right] \mathrm{Cl}(\mathbf{L H}=\mathbf{L H} \mathbf{1}(\mathbf{8})$, LH2 (9), LH3 (10)) according to elemental analysis and mass spectrometry measurements (Scheme 7). 
$\left[\mathrm{RuClH}(\mathrm{CO})\left(\mathrm{PPh}_{3}\right)_{3}\right]$

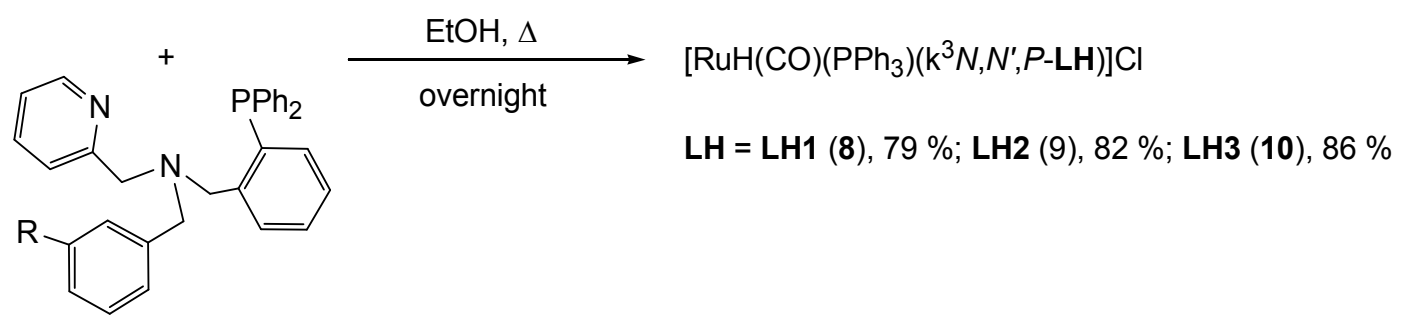

Scheme 7. Synthesis of complexes 8-10.

At $213 \mathrm{~K}$, the ${ }^{31} \mathrm{P}\left\{{ }^{1} \mathrm{H}\right\}$ NMR spectra of the isolated solids in methanol- $\mathrm{d}_{4}$ consist of two $\mathrm{AB}$ and one AX systems with a coupling constant of about $255 \mathrm{~Hz}$ for all the three

${ }^{31} \mathrm{P}$ spin systems. These data indicate the presence of three different species and the value of the coupling constants suggests that the two phosphorus atoms present in the three species are trans to each other. At the same temperature, in the hydrido region of the ${ }^{1} \mathrm{H}$ NMR spectra, two double doublets and a pseudo triplet, in $c a \cdot 2.5 / 24.5 / 73$ intensity ratio were observed. Coupling constants in the range 14-29 Hz were determined for these multiplets indicating that a hydrido ligand is located cis with respect to two phosphorus nuclei. Consistently, at $298 \mathrm{~K}$, in the ${ }^{13} \mathrm{C}\left\{{ }^{1} \mathrm{H}\right\}$ NMR spectra, the CO carbon of compounds $\mathbf{9}$ and $\mathbf{1 0}$ appears as a pseudo triplet due to two almost equal cis $J(\mathrm{PC})$ constants of about $16 \mathrm{~Hz}$.

From the 36 possible stereoisomers (18 pairs of enantiomers) for an octahedral geometry like that of complexes 8-10, namely, $\operatorname{RuABC}\left(\kappa^{3} N, N^{\prime}, P-\mathbf{D}\right)$ with one of the nitrogen atoms being stereogenic, only the four pairs of enantiomers depicted in Scheme 8 fulfill all the NMR data above mentioned. 




$\left(S_{N}\right)-O C-6-25-A$

$\mathrm{R}=\mathrm{H}(\mathbf{8 a}), \mathrm{OMe}(\mathbf{9 a}), \mathrm{CF}_{3}(\mathbf{1 0 a})$



$\mathrm{R}=\mathrm{H}(\mathbf{8 c}), \mathrm{OMe}(\mathbf{9 c}), \mathrm{CF}_{3}(\mathbf{1 0 c})$

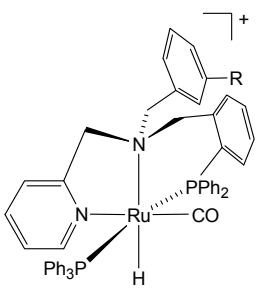

$\left(R_{N}\right)-0 C-6-25-A$

$\mathrm{R}=\mathrm{H}(\mathbf{8 b}), \mathrm{OMe}(\mathbf{9 b}), \mathrm{CF}_{3}(\mathbf{1 0 b}$

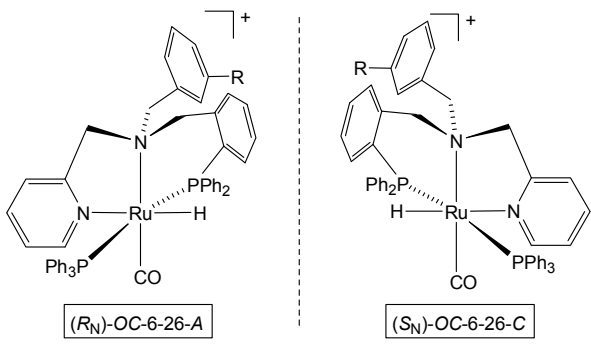

$\mathrm{R}=\mathrm{H}(\mathbf{8 d}), \mathrm{OMe}(\mathbf{9 d}), \mathrm{CF}_{3}(\mathbf{1 0 d})$

Scheme 8. Possible stereochemistries of the isolated isomers of complexes 8-10.

Single crystals of complex 10a have been obtained from dichloromethane solutions.

A view of the molecular structure is depicted in Figure 3 and relevant characteristics of the metal coordination sphere are summarized in Table 3.



Figure 3. Molecular structure of the cation of the $\left(\left(S_{N}\right)-O C-6-25-A\right)-10 a$ isomer. For clarity, hydrogen atoms (except the hydride) have been omitted and only the ipso carbons of the $\mathrm{PPh}_{2}$ and $\mathrm{PPh}_{3}$ groups are shown. 
Table 3. Selected Bonds Lengths $(\AA)$ and Angles $\left(^{\circ}\right)$ for the Complex 10a

\begin{tabular}{|l|l|l|l|}
\hline Ru-P(1) & $2.3379(10)$ & $\mathrm{P}(2)-\mathrm{Ru}-\mathrm{N}(1)$ & $103.78(8)$ \\
\hline $\mathrm{Ru}-\mathrm{P}(2)$ & $2.3798(9)$ & $\mathrm{P}(2)-\mathrm{Ru}-\mathrm{N}(2)$ & $89.20(8)$ \\
\hline $\mathrm{Ru}-\mathrm{N}(1)$ & $2.285(3)$ & $\mathrm{P}(2)-\mathrm{Ru}-\mathrm{C}(34)$ & $88.51(13)$ \\
\hline $\mathrm{Ru}-\mathrm{N}(2)$ & $2.149(3)$ & $\mathrm{P}(2)-\mathrm{Ru}-\mathrm{H}$ & $83.2(18)$ \\
\hline $\mathrm{Ru}-\mathrm{C}(34)$ & $1.829(3)$ & $\mathrm{N}(1)-\mathrm{Ru}-\mathrm{N}(2)$ & $75.83(10)$ \\
\hline $\mathrm{Ru}-\mathrm{H}$ & $1.47(5)$ & $\mathrm{N}(1)-\mathrm{Ru}-\mathrm{C}(34)$ & $100.73(13)$ \\
\hline $\mathrm{P}(1)-\mathrm{Ru}-\mathrm{P}(2)$ & $164.91(3)$ & $\mathrm{N}(1)-\mathrm{Ru}-\mathrm{H}$ & $169.1(19)$ \\
\hline $\mathrm{P}(1)-\mathrm{Ru}-\mathrm{N}(1)$ & $91.29(8)$ & $\mathrm{N}(2)-\mathrm{Ru}-\mathrm{C}(34)$ & $175.29(14)$ \\
\hline $\mathrm{P}(1)-\mathrm{Ru}-\mathrm{N}(2)$ & $93.66(8)$ & $\mathrm{N}(2)-\mathrm{Ru}-\mathrm{H}$ & $96.1(19)$ \\
\hline $\mathrm{P}(1)-\mathrm{Ru}-\mathrm{C}(34)$ & $89.61(13)$ & $\mathrm{C}(34)-\mathrm{Ru}-\mathrm{H}$ & $87.7(19)$ \\
\hline $\mathrm{P}(1)-\mathrm{Ru}-\mathrm{H}$ & $81.8(19)$ & & \\
\hline
\end{tabular}

The complex exhibits a distorted-octahedral coordination environment with the ruthenium atom bonded in a fac fashion to the phosphorus $(\mathrm{P}(1))$ and the aminic $(\mathrm{N}(1))$ and pyridinic $(\mathrm{N}(2))$ nitrogen atoms of the $\mathbf{L H 3}$ ligand. $\mathrm{A} \mathrm{PPh}_{3}$, a hydride and a $\mathrm{CO}$ ligand, trans to the $\mathrm{P}(1), \mathrm{N}(1)$ and $\mathrm{N}(2)$ atoms, respectively, complete the coordination sphere around the metal. The complex crystallizes in the $P \overline{1}$ centrosymmetric space group and therefore its unit cell $(Z=2)$ contains a pair of enantiomers of 10a, specifically the $\left(S_{\mathrm{N}}\right)-O C-6-25-A$ and $\left(R_{\mathrm{N}}\right)-O C-6-25-C^{10 \mathrm{a}, \mathrm{b}, 11}$ isomers. The strong trans influence of the hydrido ligand leads to an elongation of the Ru-N(1) bond (2.285(3) $\AA$ ) whose value is significantly longer than those of the $\mathrm{Ru}-\mathrm{N}$ (amine) bond lengths in complexes 1 (2.2144(17) $\AA$ ) and 5c (2.153(3) $\AA)$. On the contrary, both Ru-P bond lengths are similar, and close to those reported in octahedral Ru complexes with phenyl phosphine groups trans to each other (mean Ru-P bond length: $2.34(2) \AA)^{12}$

At $213 \mathrm{~K}$, the metal-hydrido region of the ${ }^{1} \mathrm{H}$ NMR spectrum consists of a pseudo triplet and a double doublet in $c a$. 75/25 molar ratio (Figure 4). The double doublet corresponding to the less abundant species $\left(213 \mathrm{~K}\right.$, about $2 \%, \delta_{\mathrm{H}}=-11.05, J(\mathrm{PH})=$ 24.1, $17.3 \mathrm{~Hz}$ ) was not detected. Hence, the equilibrium between the two major species is quickly achieved even at low temperature. Heating up the solution, these signals broaden out, coalesces at about $271 \mathrm{~K}$ resulting in a sharp pseudo triplet at $313 \mathrm{~K}$. The process obeys a first-order rate law, with derived activation parameters at $293 \mathrm{~K}$ of $\Delta \mathrm{H}^{\#}$ 
1

2

3

4

5

6

7

8

$=-0.83 \pm 0.04 \mathrm{kcal} \cdot \mathrm{mol}^{-1}, \Delta \mathrm{S}^{\#}=-44.4 \pm 5.8 \mathrm{cal} \cdot \mathrm{mol}^{-1} \cdot \mathrm{K}^{-1}$ and $\Delta \mathrm{G}^{\#}=12.19 \pm 1.75$ $\mathrm{kcal} \mathrm{mol}^{-1}$ (see Supporting Information).

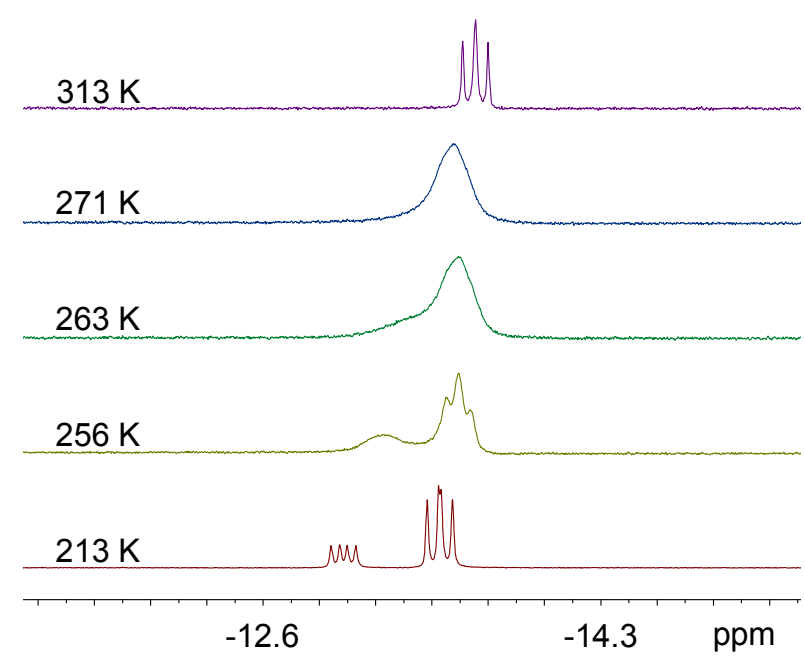

Figure 4. Evolution with the temperature of the hydrido region of the ${ }^{1} \mathrm{H}$ NMR spectra of complexes 10.

Taking into account the low value of the involved barrier, we tentatively propose that the observed fluxional process is due to an equilibrium between two conformers of the stereoisomers 10a. As mentioned before, for related fac isomers of the rhodium(III) complexes $\left[\mathrm{RhCl}_{3}\left(\kappa^{3} N, N^{\prime}, P-\mathbf{L} \mathbf{1}\right)\right]$, DFT calculations located two conformations for the six-membered Rh-P-C-C-C-N ring (see Scheme 8) that equilibrates fast at room temperature. $^{4 \mathrm{a}}$

In summary, the reaction of $\left[\mathrm{RuClH}(\mathrm{CO})\left(\mathrm{PPh}_{3}\right)_{3}\right]$ with the tripodal ligands $\mathbf{~} \mathbf{H}$ is highly diastereoselective affording high yields of a mixture of only two diastereomers. The major isomers, 8a-10a, were obtained in about 97.5/2.5 diastereomeric relation.

Refluxing in 2-ethoxyethanol for 2 days suspensions of mixtures of isomers of the complexes $\left[\mathrm{RuH}(\mathrm{CO})\left(\mathrm{PPh}_{3}\right)\left(\kappa^{3} N, N^{\prime}, P-\mathbf{L H}\right)\right] \mathrm{Cl}$ (8-10) afforded the corresponding metalated complexes $\left[\operatorname{RuCl}(\mathrm{CO})\left(\kappa^{4} C, N, N^{\prime}, P-\mathbf{L}\right)\right](\mathbf{L}=\mathbf{L 1}(\mathbf{1 1}), \mathbf{L 2}(\mathbf{1 2}), \mathbf{L 3}(\mathbf{1 3}))$. Monitoring the reaction by NMR, the only detected compounds, under the reaction 
conditions, were the starting mixture of compounds 8-10 and the isolated metalated complexes 11-13.



$\mathrm{R}=\mathrm{H}(\mathbf{8}), \mathrm{OMe}(\mathbf{9}), \mathrm{CF}_{3}(\mathbf{1 0})$

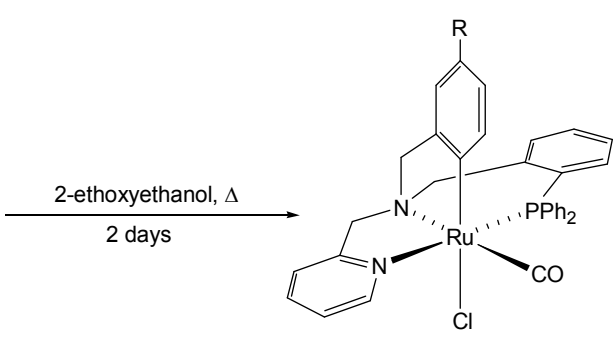

$\left(R_{N}\right)-O C-6-63-C$



$\left(S_{N}\right)-O C-6-63-A$

$\mathrm{R}=\mathrm{H}(11 \mathrm{a}), 82 \%$; OMe (12a), $\mathrm{CF}_{3}(13 \mathbf{a}), 81 \%$

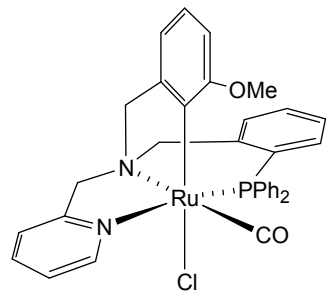

$\left(R_{\mathrm{N}}\right)-O C-6-63-C$



$\left(S_{\mathrm{N}}\right)-O C-6-63-A$

Scheme 9. Synthesis of the complexes 11-13.

Taking into account that metalation of the methoxo and trifluoromethyl substituted ligands LH2 and LH3 could take place at the C-2 or at C-6 carbons of the benzyl arm, up to 12 diastereomers as pairs of enantiomers of complexes $\mathbf{1 2}$ and $\mathbf{1 3}$ could form (6 pairs in the case of complex $\mathbf{1 1}$ derived from the unsubstituted LH1 ligand). However, whereas for the methoxo derivative metalation was observed at the two possible positions, for the trifluoromethyl derivative only metalation at C-6 carbon occurred. The preparative route is highly selective: only the distereomers 11a and 13a were detected for complexes 11 and 13. For complex 12, metalation occurs at the C-2 or at C-6 carbon and two diastereomers, 12a and $\mathbf{1 2 b}$, were isolated (Scheme 9).

The complexes have been characterized by analytical and spectroscopic methods and by the X-ray determination of their crystal structures. The three groups of diastereotopic methylene protons, labeled as $\mathrm{CH}_{2}(\mathrm{Py}), \mathrm{CH}_{2}(\mathrm{Ph})$ and $\mathrm{CH}_{2}(\mathrm{P})$, have been 
assigned through mono- and bi-dimensional homo- and hetero-nuclear NMR experiments. The ${ }^{31} \mathrm{P}\left\{{ }^{1} \mathrm{H}\right\}$ NMR spectra consist of a singlet at $c a .56 \mathrm{ppm}$, about 16 ppm downfield shifted with respect to the $\mathrm{PPh}_{2}$ signal of the starting compounds. ${ }^{13} \mathrm{C}$ resonance in the range 154-178 ppm, showing a typical cis $J(\mathrm{PC})$ coupling constant of about $11 \mathrm{~Hz}$, indicates the presence of a $\mathrm{Ru}-\mathrm{C}\left(\mathrm{sp}^{2}\right)$ bond. The value of the $J(\mathrm{PC})$ coupling constant of the carbonyl carbon, around $18 \mathrm{~Hz}$, also indicates a cis arrangement between the $\mathrm{CO}$ and $\mathrm{PPh}_{2}$ groups. The 6-CH proton of the pyridine moiety shows a $J(\mathrm{PH})$ coupling indicating a trans disposition with respect to the $\mathrm{PPh}_{2}$ group. All these data together support the geometry depicted in Scheme 8 for complexes 11-13.
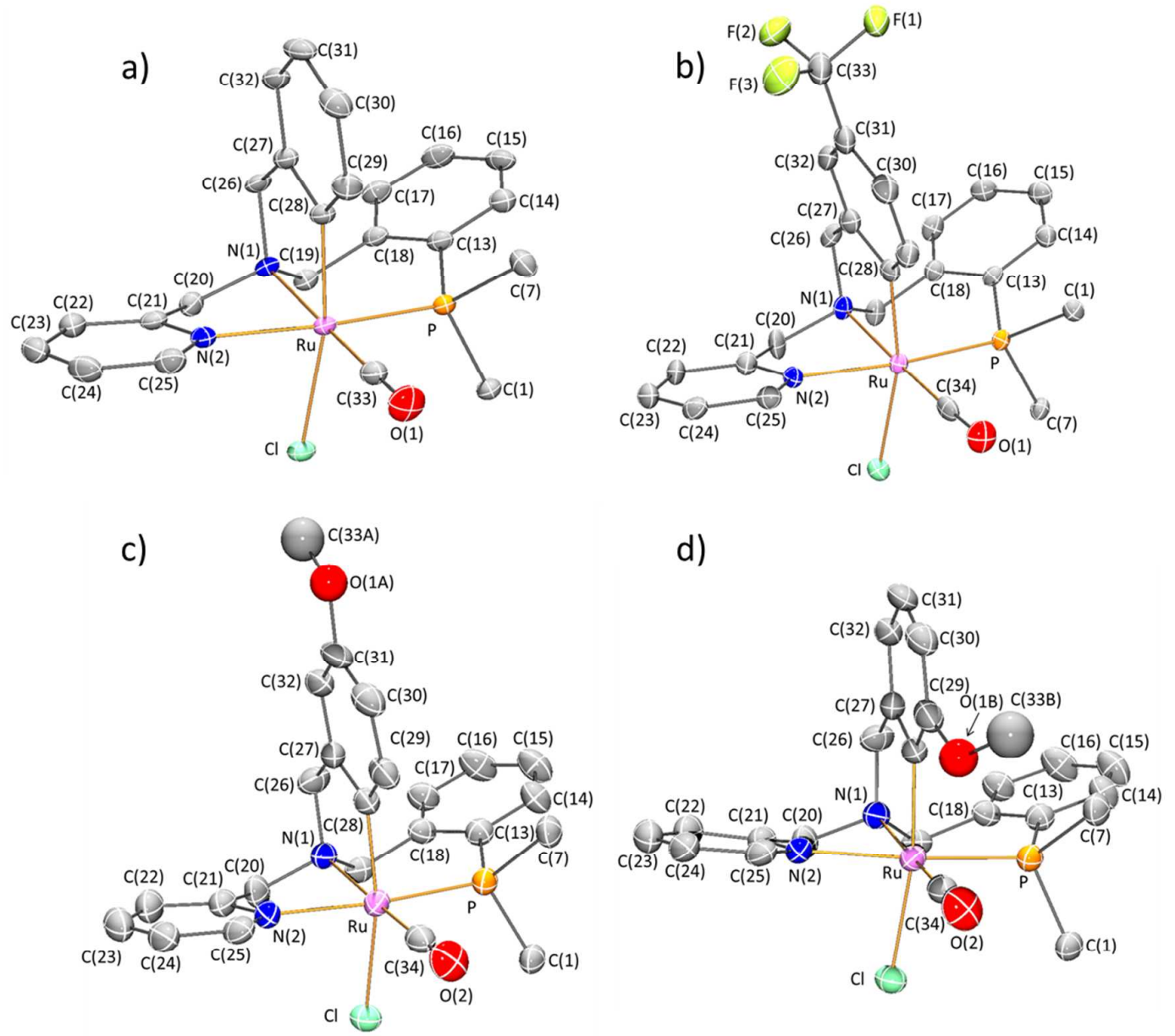

Figure 5. Molecular structure of the complexes a) $\left.\left(\left(R_{N}\right)-O C-6-63-C\right)-11 \mathrm{a}, \mathrm{b}\right)\left(\left(R_{\mathrm{N}}\right)-O C-6-63-C\right)-$ $13 \mathrm{a}, \mathrm{c})\left(\left(R_{\mathrm{N}}\right)-O C-6-63-C\right)-12 \mathrm{a}$ and d) $\left(\left(R_{\mathrm{N}}\right)-O C-6-63-C\right)-12 \mathrm{~b}$. For clarity hydrogen atoms have been omitted and only ipso carbon atoms of phenyl groups have been included. 
In order to unequivocally ascertain the structure of the metalated compounds, the crystal structures of complexes 11, 12a,b and 13 have been determined by X-ray diffraction. The crystal structure of complex $\mathbf{1 2}$ reveals the existence of a disorder between 12a and $\mathbf{1 2 b}$ isomers with a $0.765 / 0.235(5)$ proportion. A view of the molecular structure of the three complexes (including both isomers of complex 12) is depicted in Figure 5 and the structural parameters of the metal coordination spheres are listed in Table 4.

Table 4. Selected Bond Lengths $(\AA)$ and Angles $\left({ }^{\circ}\right)$ for the Complexes 11a, 12a,b, and 13a

\begin{tabular}{|c|c|c|c|}
\hline & $11 a$ & $12 a, b$ & $13 a$ \\
\hline $\mathrm{Ru}-\mathrm{Cl}$ & $2.5070(8)$ & $2.5314(12)$ & $2.5316(13)$ \\
\hline Ru-P & $2.2857(8)$ & $2.2954(13)$ & $2.2918(12)$ \\
\hline Ru-N(1) & $2.186(2)$ & $2.180(4)$ & $2.175(4)$ \\
\hline Ru-N(2) & $2.128(3)$ & $2.131(4)$ & $2.134(4)$ \\
\hline Ru-C(28) & $2.040(3)$ & $2.047(4)$ & $2.041(5)$ \\
\hline $\mathrm{Ru}-\mathrm{C}_{(\mathrm{CO})}{ }^{\mathrm{a}}$ & $1.834(3)$ & $1.838(6)$ & $1.859(5)$ \\
\hline Cl-Ru-P & $95.25(3)$ & $92.68(4)$ & $94.49(4)$ \\
\hline $\mathrm{Cl}-\mathrm{Ru}-\mathrm{N}(1)$ & $88.98(7)$ & $87.35(10)$ & $88.59(12)$ \\
\hline Cl-Ru-N(2) & $84.15(7)$ & $88.05(10)$ & $85.29(11)$ \\
\hline Cl-Ru-C(28) & $168.50(9)$ & $167.57(13)$ & $166.30(14)$ \\
\hline $\mathrm{Cl}-\mathrm{Ru}-\mathrm{C}_{(\mathrm{CO})^{\mathrm{a}}}$ & $94.70(10)$ & $97.51(14)$ & $95.09(15)$ \\
\hline P-Ru-N(1) & $92.44(7)$ & 93.24(11) & 93.03(11) \\
\hline P-Ru-N(2) & $171.51(8)$ & $171.75(12)$ & 171.61(12) \\
\hline P-Ru-C(28) & $92.44(8)$ & $93.33(13)$ & $96.29(13)$ \\
\hline $\mathrm{P}-\mathrm{Ru}-\mathrm{C}_{(\mathrm{CO})}{ }^{\mathrm{a}}$ & $89.95(10)$ & $89.46(15)$ & $88.22(15)$ \\
\hline $\mathrm{N}(1)-\mathrm{Ru}-\mathrm{N}(2)$ & $79.10(10)$ & $78.58(15)$ & $78.58(16)$ \\
\hline $\mathrm{N}(1)-\mathrm{Ru}-\mathrm{C}(28)$ & $82.14(11)$ & $81.46(17)$ & $82.44(19)$ \\
\hline $\mathrm{N}(1)-\mathrm{Ru}-\mathrm{C}_{(\mathrm{Co})}{ }^{\mathrm{a}}$ & $175.42(12)$ & $174.33(17)$ & 176.02(19) \\
\hline $\mathrm{N}(2)-\mathrm{Ru}-\mathrm{C}(28)$ & $86.98(11)$ & $84.46(16)$ & $82.81(17)$ \\
\hline $\mathrm{N}(2)-\mathrm{Ru}-\mathrm{C}_{(\mathrm{CO})}{ }^{\mathrm{a}}$ & $98.54(12)$ & $98.59(18)$ & $100.15(18)$ \\
\hline $\mathrm{C}(28)-\mathrm{Ru}-\mathrm{C}_{(\mathrm{CO})}{ }^{\mathrm{a}}$ & $93.85(13)$ & $93.41(19)$ & $93.7(2)$ \\
\hline
\end{tabular}

Their molecular structure illustrated distorted-octahedral coordination geometries around the central metal atom. One chlorido and one carbonyl ligand occupy two cis coordination sites and the four donating atoms of the tripodal tetradentate ligand complete the metal coordination sphere. As indicated by solution NMR data, the phosphorus atom is trans to the pyridinic nitrogen $\mathrm{N}(2)$, while the chlorido is found to be trans to the aromatic $\mathrm{C}(28)$ atom and the CO ligand is trans to the aminic nitrogen $\mathrm{N}(1)$. The aminic nitrogen and the metal are stereogenic centers. The crystal structure of 
the three complexes contains an inversion center and, therefore, the enantiomeric pairs of diastereomers 11a, 12a,b and 13a (see Scheme 8) are present in their unit cells.

Taking into account the potential application of these compounds as catalyst precursors in asymmetric transformations, it is interesting to point out that the phenyl groups of the phosphano arm of the ligand $\mathbf{L}$ shields one of the faces of the coordination plane containing the chlorido and carbonyl ligands (Figure 6). However, the other face of this plane remains essentially clear. Hence, if a prochiral planar chelate replaces these ligands, one of its enantiofaces would be better shielded than the other and, therefore, enantioselective attacks would be anticipated.
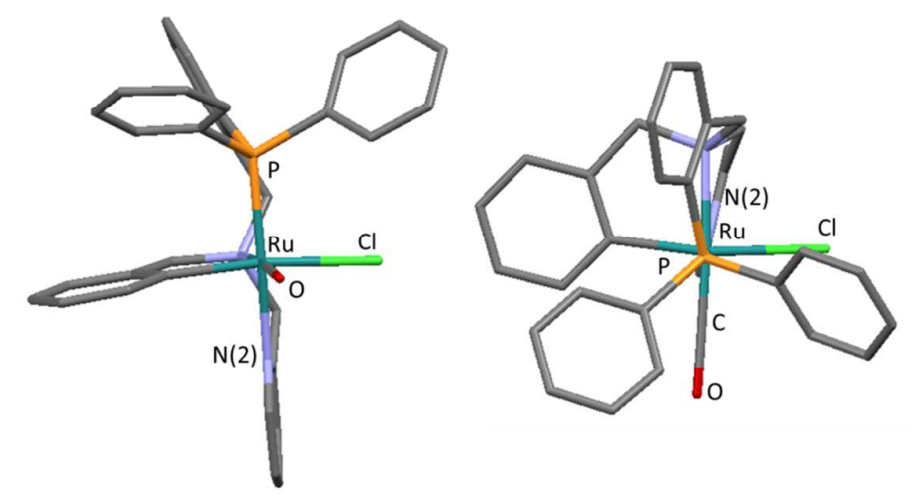

Figure 6. Views of isomer 11a, $\left(R_{\mathrm{N}}\right)-\mathrm{OC}-6-63-C$, along the $\mathrm{OC}-\mathrm{Ru}$ and $\mathrm{P}-\mathrm{Ru}$ directions. Similar projections are obtained for complexes $12 \mathrm{a}, 12 \mathrm{~b}$ and $13 \mathrm{a}$. 


\section{CONCLUSIONS}

Ligands LH1-LH3 react with the ruthenium compounds $\left[\{(\mathrm{Cy}) \mathrm{RuCl}\}_{2}(\mu-\mathrm{Cl})_{2}\right]$, $\left[\mathrm{RuCl}_{2}\left(\mathrm{PPh}_{3}\right)_{3}\right]$ or $\left[\mathrm{RuClH}(\mathrm{CO})\left(\mathrm{PPh}_{3}\right)_{3}\right]$ affording tricoordinate $\mathrm{k}^{3} N, \mathrm{~N}^{\prime}, \mathrm{P}$ complexes of $\mathrm{d}^{6} \mathrm{Ru}^{2+}$ ions of general formula $\left[\mathrm{RuABC}\left(\kappa^{3} N, N^{\prime}, P-\mathbf{L H}\right)\right]^{\mathrm{n}+}$ in which $\mathrm{A}, \mathrm{B}$ and $\mathrm{C}$ represent $p$-cymene or three equal or different, anionic or neutral, monodentate ligands. In these complexes, the metal and aminic nitrogen atoms are stereogenic centers. All the preparative routes investigated are highly diastereoselective: from the total number of possible isomers that could form, only a reduced number have been detected in each case. Metalated complexes of formula $\left[\mathrm{RuCl}(\mathrm{CO})\left(\kappa^{4} C, N, N^{\prime}, P-\mathbf{L}\right)\right]$ have been isolated starting from neutral compounds of formula $\left[\mathrm{RuClH}(\mathrm{CO})\left(\kappa^{3} N, N^{\prime}, P-\mathbf{L H}\right)\right]$. Probably, the presence of a carbonyl group (a strong $\pi$-acceptor ligand) facilitates the orthometalation process. Again, the synthesis is stereoselective: only one diastereomer was detected for the ligands $\mathbf{L} 1$ and $\mathbf{L} 3$ but two, derived from metalation at the C-2 or C-6 carbon of the benzylic arm, for the ligand $\mathbf{L} 2$.

Notably, the asymmetry generated by the stereogenic centers present in the metalated molecules makes the equatorial plane, defined by the metal and the two ligating atoms of the auxiliary ligands $\mathrm{Cl}$ and $\mathrm{CO}$, stereochemically differentiated. Consequently, these metalated compounds are potentially good starting materials for the preparation of enantioselective catalysts after optical resolution. We are currently making efforts in this line in our laboratory. 


\section{EXPERIMENTAL SECTION}

\section{General Information}

All preparations have been carried out under argon, unless otherwise stated. All solvents were treated in a PS-400-6 Innovative Technologies Solvent Purification System (SPS) and degassed prior to use. Carbon, hydrogen and nitrogen analyses were performed using a Perkin-Elmer $240 \mathrm{~B}$ microanalyzer. ${ }^{1} \mathrm{H},{ }^{13} \mathrm{C},{ }^{31} \mathrm{P}$ and ${ }^{19} \mathrm{~F}$ spectra were recorded on a Varian UNITY 300, a Bruker AV-300, a Bruker AV-400 or a Bruker AV-500 spectrometers. Chemical shifts are expressed in ppm up field from $\mathrm{SiMe}_{4}, 85 \% \mathrm{H}_{3} \mathrm{PO}_{4}$ $\left({ }^{31} \mathrm{P}\right)$ or $\mathrm{CFCl}_{3}\left({ }^{19} \mathrm{~F}\right) . J$ values are given in Hz. COSY, NOESY, HSQC, HMQC, and HMBC ${ }^{1} \mathrm{H}-\mathrm{X}\left(\mathrm{X}={ }^{1} \mathrm{H},{ }^{13} \mathrm{C},{ }^{31} \mathrm{P}\right)$ correlation spectra were obtained using standard procedures. Infrared spectra were recorded on a Perkin-Elmer Spectrum One FT IR spectrophotometer. Mass spectra were obtained with a Micro Tof-Q Bruker Daltonics spectrometer.

Preparation and characterization of the complexes $\left[(\mathrm{Cy}) \mathrm{Ru}\left(\kappa^{3} N, N^{\prime}, P-\mathrm{LH}\right)\right]\left[\mathrm{SbF}_{6}\right]_{2}$ (LH = LH1 (1), LH2 (2), LH3 (3)). To a solution of the ruthenium dimer $\left[\{(\mathrm{Cy}) \mathrm{RuCl}\}_{2}(\mu-\mathrm{Cl})_{2}\right](250.0 \mathrm{mg}, 0.408 \mathrm{mmol})$ in $40 \mathrm{~mL}$ of acetone, $560.7 \mathrm{mg}(1.632$ mmol) of $\mathrm{AgSbF}_{6}$ were added. The orange solution was stirred for $4 \mathrm{~h}$ and then was filtered to remove any insoluble material. To the filtrate, $0.816 \mathrm{mmol}$ of ligand $\mathbf{L H}$ (385.6 mg of LH1, $410.1 \mathrm{mg}$ of LH2 or $441.1 \mathrm{mg}$ of $\mathbf{L H 3}$ ) were added. The resulting solution was stirred for $1 \mathrm{~h}$ and then concentrated under reduced pressure to $c a .3 \mathrm{~mL}$. The slow addition of $\mathrm{Et}_{2} \mathrm{O}$ led to the precipitation of an orange solid which was washed with $\mathrm{Et}_{2} \mathrm{O}(3 \times 10 \mathrm{~mL})$ and vacuum-dried to give an analytical pure compound. Yield: $\mathbf{1}$, $820.8 \mathrm{mg}(85 \%) ; \mathbf{2}, 865.4 \mathrm{mg}(88 \%) ; \mathbf{3}, 828.4 \mathrm{mg}(81 \%)$. Crystals of 1 and $\mathbf{2}$ suitable for X-ray analysis were obtained by crystallization from $\mathrm{CH}_{2} \mathrm{Cl}_{2} /$ pentane solutions. 


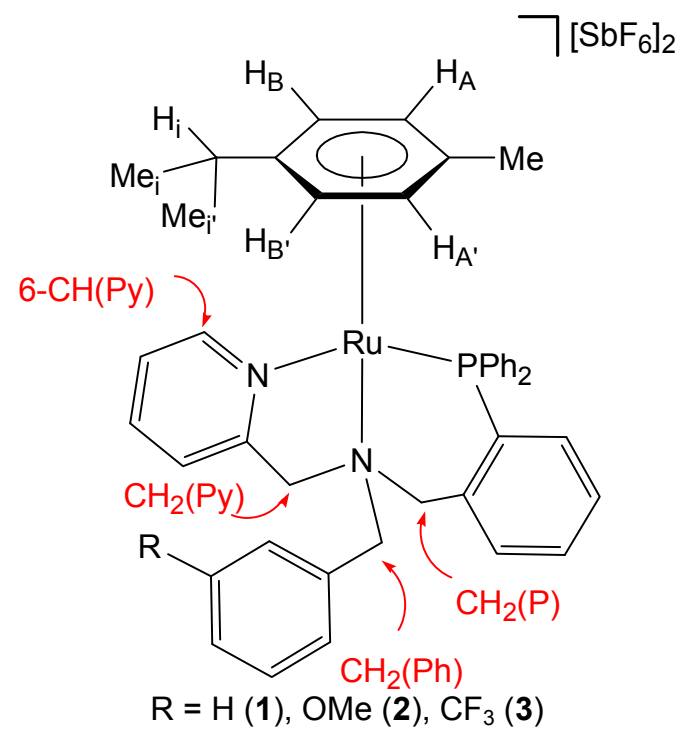

Compound 1. Anal. calcd. for $\mathrm{C}_{42} \mathrm{H}_{43} \mathrm{~F}_{12} \mathrm{~N}_{2} \mathrm{PRuSb}_{2}$ : C, 42.78; H, 3.68; N, 2.37.

Found: C, 42.82; H, 3.79; N, 2.41. IR $\left(\mathrm{cm}^{-1}\right): v\left(\mathrm{SbF}_{6}\right) 653$ (s). HRMS ( $\left.\mu-\mathrm{TOF}\right)$ : $\mathrm{C}_{42} \mathrm{H}_{43} \mathrm{~F}_{12} \mathrm{~N}_{2} \mathrm{PRuSb}_{2}\left[\mathrm{M}-\mathrm{SbF}_{6}\right]^{+}$: calc. 943.1158, found 943.1195. ${ }^{1} H$ NMR (300.13 MHz, acetone- $\left.d_{6}, R T, p p m\right): \delta=8.97$ (d, $\left.J=5.5 \mathrm{~Hz}, 1 \mathrm{H}, 6-\mathrm{CH}(\mathrm{Py})\right), 8.13-6.92(\mathrm{~m}, 22 \mathrm{H}$, $\mathrm{H}(\mathrm{Ar})$ ), 7.31 (overlapped, 1H, $\mathrm{H}_{\mathrm{B}}$ ), 6.77 (brd, $J=6.2 \mathrm{~Hz}, 1 \mathrm{H}, \mathrm{H}_{\mathrm{A}^{\prime}}$ ), 6.30 (dd, $J=6.7$, $\left.1.3 \mathrm{~Hz}, 1 \mathrm{H}, \mathrm{H}_{\mathrm{B}}\right), 5.66\left(\mathrm{~d}, J=13.4 \mathrm{~Hz}, 1 \mathrm{H}, \mathrm{CH}_{2}(\mathrm{Ph})\right), 5.48(\mathrm{~d}, J=16.1 \mathrm{~Hz}, 1 \mathrm{H}$, $\left.\mathrm{CH}_{2}(\mathrm{Py})\right), 5.26\left(\mathrm{~m}, 2 \mathrm{H}, \mathrm{H}_{\mathrm{A}}, \mathrm{CH}_{2}(\mathrm{Ph})\right), 4.95\left(\mathrm{~d}, J=16.1 \mathrm{~Hz}, 1 \mathrm{H}, \mathrm{CH}_{2}(\mathrm{Py})\right), 3.56(\mathrm{dd}, J=$ 13.6, $\left.1.7 \mathrm{~Hz}, 1 \mathrm{H}, \mathrm{CH}_{2}(\mathrm{P})\right), 3.36\left(\mathrm{dd}, J=14.1,4.7 \mathrm{~Hz}, 1 \mathrm{H}, \mathrm{CH}_{2}(\mathrm{P})\right), 2.66$ (sept, $J=6.9$ $\left.\mathrm{Hz}, 1 \mathrm{H}, \mathrm{H}_{\mathrm{i}}\right), 2.38(\mathrm{~s}, 3 \mathrm{H}, \mathrm{Me}), 1.13\left(\mathrm{~d}, J=6.9 \mathrm{~Hz}, 3 \mathrm{H}, \mathrm{Me}_{\mathrm{i}}\right)$, and $0.98(\mathrm{~d}, J=6.9 \mathrm{~Hz}$, $\left.3 \mathrm{H}, \mathrm{Me}_{\mathrm{i}}\right) .{ }^{13} C_{\left\{{ }^{1} H\right\}} \mathrm{NMR}(75.48 \mathrm{MHz}$, acetone-d $6, R T, p p m): \delta=162.55$ (s, 2-C(Py)), 157.06 (s, 6-CH(Py)), 141.40 (s, CH(Ar)), 138.01 (d, $J=15.2 \mathrm{~Hz}, 2-\mathrm{C}(\mathrm{PhP})), 136.32$ (d, $J=11.4 \mathrm{~Hz}, 2 \mathrm{C}, \mathrm{CH}(\mathrm{Ar})), 134.99$ (d, $J=2.3 \mathrm{~Hz}, \mathrm{CH}(\mathrm{Ar})), 134.31$ (d, $J=10.2 \mathrm{~Hz}$, 2C, $\mathrm{CH}(\mathrm{Ar})), 134.20$ (d, $J=9.3 \mathrm{~Hz}, \mathrm{CH}(\mathrm{Ar})), 134.06$ (d, $J=2.7 \mathrm{~Hz}, \mathrm{CH}(\mathrm{Ar})), 133.19$ (s, 2C, $\mathrm{CH}(\mathrm{Ar})), 132.46$ (d, $J=2.3 \mathrm{~Hz}, \mathrm{CH}(\mathrm{Ar})), 132.03$ (s, 1-C(Ph)), 131.34 (d, $J=$ $11.1 \mathrm{~Hz}, 2 \mathrm{C}, \mathrm{CH}(\mathrm{Ar})), 131.15$ (d, $J=10.9 \mathrm{~Hz}, 2 \mathrm{C}, \mathrm{CH}(\mathrm{Ar})), 130.93$ (d, $J=8.1 \mathrm{~Hz}$, CH(Ar)), 130.73 (s, CH(Ar)), 130.45 (d, $J=2.6 \mathrm{~Hz}, \mathrm{CH}(\mathrm{Ar})), 129.74$ (s, 2C, CH(Ar)), 129.70 (d, $J=51.6 \mathrm{~Hz}, \mathrm{C}(\mathrm{Ar})), 128.20$ (d, $J=47.0 \mathrm{~Hz}, \mathrm{C}(\mathrm{Ar})), 126.91$ (s, CH(Ar)), 
$125.79(\mathrm{~d}, J=52.2 \mathrm{~Hz}, \mathrm{C}(\mathrm{Ar})), 125.13$ (s, CH(Ar)), 121.73 (d, $J=5.9 \mathrm{~Hz}, \mathrm{C}(\mathrm{Cy})$ ), $109.70(\mathrm{~s}, \mathrm{C}(\mathrm{Cy})), 97.31\left(\mathrm{~d}, J=5.4 \mathrm{~Hz}, \mathrm{C}_{\mathrm{B}}\right), 92.11\left(\mathrm{~s}, \mathrm{C}_{\mathrm{A}}\right), 89.99\left(\mathrm{~s}, \mathrm{C}_{\mathrm{A}}{ }^{\prime}\right), 88.81\left(\mathrm{~s}, \mathrm{C}_{\mathrm{B}}\right)$, $76.09\left(\mathrm{~s}, \mathrm{CH}_{2}(\mathrm{Ph})\right), 73.19$ (s, $\left.\mathrm{CH}_{2}(\mathrm{Py})\right), 64.29$ (d, $\left.J=11.6 \mathrm{~Hz}, \mathrm{CH}_{2}(\mathrm{P})\right), 32.12\left(\mathrm{~s}, \mathrm{C}_{\mathrm{Hi}}\right)$, $22.59\left(\mathrm{~s}, \mathrm{Me}_{\mathrm{i}}\right), 21.82\left(\mathrm{~s}, \mathrm{Me}_{\mathrm{i}}\right)$, and $19.65(\mathrm{~s}, \mathrm{Me}) .{ }^{31} P\left\{{ }^{1} H\right\} N M R(121.42 \mathrm{MHz}$, acetone$\left.d_{6}, R T, p p m\right): \delta=39.83(\mathrm{~s})$.

Compound 2. Anal. calcd. for $\mathrm{C}_{43} \mathrm{H}_{45} \mathrm{~F}_{12} \mathrm{~N}_{2} \mathrm{OPRuSb}{ }_{2}$ : C, 42.71; H, 3.75; N, 2.32 . Found: C, 42.92; H, 3.46; N, 2.39. IR $\left(\mathrm{cm}^{-1}\right): v\left(\mathrm{SbF}_{6}\right) 653$ (s). HRMS ( $\left.\mu-\mathrm{TOF}\right)$ : $\mathrm{C}_{43} \mathrm{H}_{45} \mathrm{~F}_{12} \mathrm{~N}_{2} \mathrm{OPRuSb} b_{2}\left[\mathrm{M}-\mathrm{H}-\left(\mathrm{SbF}_{6}\right)_{2}\right]^{+}$: calc. 737.2241 , found 737.2260 . ${ }^{1} H$ NMR (300.13 MHz, acetone- $\left.d_{6}, R T, p p m\right): \delta=8.85(\mathrm{~d}, J=5.7 \mathrm{~Hz}, 1 \mathrm{H}, 6-\mathrm{CH}(\mathrm{Py})), 7.92-6.81$ (m, 21H, H(Ar)), 7.25 (overlapped, 1H, $\mathrm{H}_{\mathrm{B}}$ ) $, 6.64\left(\mathrm{~d}, J=6.2 \mathrm{~Hz}, 1 \mathrm{H}, \mathrm{H}_{\mathrm{A}^{\prime}}\right), 6.18(\mathrm{~d}, J=$ $\left.6.7 \mathrm{~Hz}, 1 \mathrm{H}, \mathrm{H}_{\mathrm{B}}\right), 5.50\left(\mathrm{~d}, J=13.0 \mathrm{~Hz}, 1 \mathrm{H}, \mathrm{CH}_{2}(\mathrm{Ph})\right), 5.38(\mathrm{~d}, J=16.6 \mathrm{~Hz}, 1 \mathrm{H}$, $\left.\mathrm{CH}_{2}(\mathrm{Py})\right), 5.12\left(\mathrm{~m}, 2 \mathrm{H}, \mathrm{H}_{\mathrm{A}}, \mathrm{CH}_{2}(\mathrm{Ph})\right), 4.91$ (d, J=16.5 Hz, 1H, $\left.\mathrm{CH}_{2}(\mathrm{Py})\right), 3.67$ (s, 3H, OMe), 3.41 (brd, $\left.J=13.8 \mathrm{~Hz}, 1 \mathrm{H}, \mathrm{CH}_{2}(\mathrm{P})\right), 3.23$ (dd, $J=13.9,4.6 \mathrm{~Hz}, 1 \mathrm{H}, \mathrm{CH}_{2}(\mathrm{P})$ ), 2.53 (sept, $\left.J=6.9 \mathrm{~Hz}, 1 \mathrm{H}, \mathrm{H}_{\mathrm{i}}\right), 2.25(\mathrm{~s}, 3 \mathrm{H}, \mathrm{Me}), 1.00\left(\mathrm{~d}, J=6.9 \mathrm{~Hz}, 3 \mathrm{H}, \mathrm{Me}_{\mathrm{i}}\right)$, and 0.84 $\left.\left(\mathrm{d}, J=6.9 \mathrm{~Hz}, 3 \mathrm{H}, \mathrm{Me}_{\mathrm{i}}\right) .{ }^{13} C_{\{}{ }^{1} H\right\} N M R\left(75.48 \mathrm{MHz}\right.$, acetone-d $\left.{ }_{6}, R T, p p m\right): \delta=162.11$ (s, 2-C(Py)), 160.52 (s, C(OMe)), 156.78 (d, $J=1.6 \mathrm{~Hz}, 6-\mathrm{CH}(\mathrm{Py})), 141.09$ (s, $\mathrm{CH}(\mathrm{Ar})), 137.86(\mathrm{~d}, J=13.3 \mathrm{~Hz}, 2-\mathrm{C}(\mathrm{PhP})), 136.06$ (d, $J=11.9 \mathrm{~Hz}, 2 \mathrm{C}, \mathrm{CH}(\mathrm{Ar}))$, 134.17 (d, $J=2.7 \mathrm{~Hz}, \mathrm{CH}(\mathrm{Ar})), 134.02$ (d, $J=10.2 \mathrm{~Hz}, 2 \mathrm{C}, \mathrm{CH}(\mathrm{Ar})), 133.93$ (d, $J=$ 9.6 Hz, CH(Ar)), 133.75 (d, $J=2.5 \mathrm{~Hz}, \mathrm{CH}(\mathrm{Ar})), 133.18$ (s, 1-C(Ph)), 132.13 (d, $J=$ $2.5 \mathrm{~Hz}, \mathrm{CH}(\mathrm{Ar})), 131.05$ (d, $J=11.1 \mathrm{~Hz}, 2 \mathrm{C}, \mathrm{CH}(\mathrm{Ar})), 130.86$ (d, $J=10.9 \mathrm{~Hz}, 2 \mathrm{C}$, CH(Ar)), 130.58 (d, $J=8.1 \mathrm{~Hz}, \mathrm{CH}(\mathrm{Ar})), 130.53$ (s, $\mathrm{CH}(\mathrm{Ar})), 130.13$ (d, $J=2.9 \mathrm{~Hz}$, CH(Ar)), 130.04 (d, $J=55.5 \mathrm{~Hz}, \mathrm{C}(\mathrm{Ar})), 127.90$ (d, $J=47.0 \mathrm{~Hz}, \mathrm{C}(\mathrm{Ar})), 126.60$ (s, $\mathrm{CH}(\mathrm{Ar})), 125.48$ (d, $J=54.0 \mathrm{~Hz}, \mathrm{C}(\mathrm{Ar})), 124.85$ (s, 2C, $\mathrm{CH}(\mathrm{Ar})), 121.34$ (d, $J=4.5$ Hz, C(Cy)), 118.61 (s, CH(Ar)), 115.45 (s, CH(Ar)), 109.33 (s, C(Cy)), 97.02 (d, J = $\left.4.6 \mathrm{~Hz}, \mathrm{C}_{\mathrm{B}}\right), 91.73\left(\mathrm{~s}, \mathrm{C}_{\mathrm{A}}\right), 89.66\left(\mathrm{~s}, \mathrm{C}_{\mathrm{A}^{\prime}}\right), 88.49\left(\mathrm{~s}, \mathrm{C}_{\mathrm{B}}\right), 75.66\left(\mathrm{~s}, \mathrm{CH}_{2}(\mathrm{Ph})\right), 73.12(\mathrm{~s}$, 
$\left.\mathrm{CH}_{2}(\mathrm{Py})\right), 64.03$ (d, $\left.J=11.4 \mathrm{~Hz}, \mathrm{CH}_{2}(\mathrm{P})\right), 55.43$ (s, OMe), 31.79 (s, $\mathrm{C}_{\mathrm{Hi}}$ ), 22.31 (s, $\mathrm{Me}_{\mathrm{i}}$ ), $21.47\left(\mathrm{~s}, \mathrm{Me}_{\mathrm{i}}\right.$ ), and 19.45 (s, Me). ${ }^{31} P\left\{{ }^{1} H\right\} N M R$ (121.42 MHz, acetone- $d_{6}, R T$, ppm): $\delta=39.82(\mathrm{~s})$.

Compound 3. Anal. calcd. for $\mathrm{C}_{43} \mathrm{H}_{42} \mathrm{~F}_{15} \mathrm{~N}_{2} \mathrm{PRuSb}_{2}$ : C, 41.41; H, 3.39; N, 2.25. Found: C, 41.68; H, 3.58; N, 2.42. IR $\left(\mathrm{cm}^{-1}\right): v\left(\mathrm{SbF}_{6}\right) 653$ (s). HRMS ( $\mu$-TOF): $\mathrm{C}_{43} \mathrm{H}_{42} \mathrm{~F}_{15} \mathrm{~N}_{2} \mathrm{PRuSb}_{2} \quad\left[\mathrm{M}-\mathrm{H}-\left(\mathrm{SbF}_{6}\right)_{2}\right]^{+}$: calc. 775.2009, found 775.1999. ${ }^{1} H$ NMR (400.16 MHz, acetone- $\left.d_{6}, R T, p p m\right): \delta=8.96(\mathrm{~d}, J=5.7 \mathrm{~Hz}, 1 \mathrm{H}, 6-\mathrm{CH}(\mathrm{Py})), 8.06-6.96$ (m, 21H, H(Ar)), $7.30\left(\mathrm{dd}, J=6.2,1.0 \mathrm{~Hz}, 1 \mathrm{H}, \mathrm{H}_{\mathrm{B}}{ }^{\prime}\right), 6.75\left(\mathrm{dd}, J=6.3,1.0 \mathrm{~Hz}, 1 \mathrm{H}, \mathrm{H}_{\mathrm{A}^{\prime}}\right)$, $6.29\left(\mathrm{dd}, J=6.0,1.1 \mathrm{~Hz}, 1 \mathrm{H}, \mathrm{H}_{\mathrm{B}}\right), 5.81\left(\mathrm{~d}, J=13.5 \mathrm{~Hz}, 1 \mathrm{H}, \mathrm{CH}_{2}(\mathrm{Ph})\right), 5.60(\mathrm{brd}, J=$ 15.6 Hz, 1H, $\left.\mathrm{CH}_{2}(\mathrm{Py})\right), 5.42$ (d, $\left.J=13.5 \mathrm{~Hz}, 1 \mathrm{H}, \mathrm{CH}_{2}(\mathrm{Ph})\right), 5.29$ (ddd, $J=6.7,3.1,1.2$ $\left.\mathrm{Hz}, 1 \mathrm{H}, \mathrm{H}_{\mathrm{A}}\right), 5.06\left(\mathrm{~d}, J=15.8 \mathrm{~Hz}, 1 \mathrm{H}, \mathrm{CH}_{2}(\mathrm{Py})\right), 3.65(\mathrm{dd}, J=13.7,1.8 \mathrm{~Hz}, 1 \mathrm{H}$, $\left.\mathrm{CH}_{2}(\mathrm{P})\right), 3.46\left(\mathrm{dd}, J=13.7,4.7 \mathrm{~Hz}, 1 \mathrm{H}, \mathrm{CH}_{2}(\mathrm{P})\right), 2.67$ (sept, $\left.J=7.0 \mathrm{~Hz}, 1 \mathrm{H}, \mathrm{H}_{\mathrm{i}}\right), 2.39$ (s, 3H, Me), $1.13\left(\mathrm{~d}, J=7.0 \mathrm{~Hz}, 3 \mathrm{H}, \mathrm{Me}_{\mathrm{i}}\right)$, and $0.99\left(\mathrm{~d}, J=7.0 \mathrm{~Hz}, 3 \mathrm{H}, \mathrm{Me}_{\mathrm{i}}\right) .{ }^{13} C_{\{}{ }^{1} H_{\}}$ NMR (100.62 MHz, acetone- $d_{6}, R T$, ppm): $\delta=162.40$ (s, 2-C(Py)), 157.02 (s, 6CH(Py)), 141.44 (s, CH(Ar)), 137.94 (d, $J=15.3 \mathrm{~Hz}, 2-\mathrm{C}(\mathrm{PhP})), 137.21$ (d, $J=2.7 \mathrm{~Hz}$, CH(Ar)), 136.31 (d, $J=11.3 \mathrm{~Hz}, 2 \mathrm{C}, \mathrm{CH}(\mathrm{Ar})), 134.45$ (d, $J=2.3 \mathrm{~Hz}, \mathrm{CH}(\mathrm{Ar})), 134.28$ (d, $J=10.2 \mathrm{~Hz}, 2 \mathrm{C}, \mathrm{CH}(\mathrm{Ar})), 134.27$ (d, $J=9.4 \mathrm{~Hz}, \mathrm{CH}(\mathrm{Ar})), 134.02$ (d, $J=2.8 \mathrm{~Hz}$, CH(Ar)), 133.26 (s, 1-C(Ph)), 132.44 (d, $J=2.0 \mathrm{~Hz}, \mathrm{CH}(\mathrm{Ar})), 131.47$ (d, $J=11.1 \mathrm{~Hz}$, 2C, $\mathrm{CH}(\mathrm{Ar})), 131.37$ (q, $\left.J=32.6 \mathrm{~Hz}, \mathrm{C}\left(\mathrm{CF}_{3}\right)\right), 131.17$ (d, $J=10.8 \mathrm{~Hz}, 2 \mathrm{C}, \mathrm{CH}(\mathrm{Ar})$ ), 130.97 (d, $J=8.1 \mathrm{~Hz}, \mathrm{CH}(\mathrm{Ar})), 130.85$ (s, CH(Ar)), 130.44 (d, $J=2.6 \mathrm{~Hz}, \mathrm{CH}(\mathrm{Ar})$ ), $130.31(\mathrm{~d}, J=55.9 \mathrm{~Hz}, \mathrm{C}(\mathrm{Ar})), 129.66$ (q, $J=3.8 \mathrm{~Hz}, \mathrm{CH}(\mathrm{Ar})), 128.14$ (d, $J=47.1 \mathrm{~Hz}$, C(Ar)), 127.50 (q, $J=3.8 \mathrm{~Hz}, \mathrm{CH}(\mathrm{Ar})), 126.98$ (s, CH(Ar)), 125.75 (d, $J=54.0 \mathrm{~Hz}$, C(Ar)), 125.13 (s, CH(Ar)), 124.98 (q, $\left.J=271.5 \mathrm{~Hz}, \mathrm{CF}_{3}\right), 121.91$ (d, $J=6.0 \mathrm{~Hz}$, C(Cy)), $109.66(\mathrm{~s}, \mathrm{C}(\mathrm{Cy})), 97.02\left(\mathrm{~d}, J=5.5 \mathrm{~Hz}, \mathrm{C}_{\mathrm{B}^{\prime}}\right), 92.18\left(\mathrm{~s}, \mathrm{C}_{\mathrm{A}}\right), 90.11\left(\mathrm{~s}, \mathrm{C}_{\mathrm{A}^{\prime}}\right)$, $88.57\left(\mathrm{~s}, \mathrm{C}_{\mathrm{B}}\right), 75.06\left(\mathrm{~s}, \mathrm{CH}_{2}(\mathrm{Ph})\right), 73.10\left(\mathrm{~s}, \mathrm{CH}_{2}(\mathrm{Py})\right), 64.26\left(\mathrm{~d}, J=11.2 \mathrm{~Hz}, \mathrm{CH}_{2}(\mathrm{P})\right)$, 
$32.09\left(\mathrm{~s}, \mathrm{C}_{\mathrm{Hi}}\right), 22.52\left(\mathrm{~s}, \mathrm{Me}_{\mathrm{i}}\right), 21.80\left(\mathrm{~s}, \mathrm{Me}_{\mathrm{i}}\right)$, and $\left.19.65(\mathrm{~s}, \mathrm{Me}) .{ }^{19} F_{\{}{ }^{1} H\right\} N M R(282.33$ MHz, acetone-d $\left.d_{6}, R T, p p m\right): \delta=-62.90$ (s). ${ }^{31} P\left\{{ }^{1} H\right\} N M R\left(161.98 M H z\right.$, acetone- $d_{6}, R T$, ppm): $\delta=39.52(\mathrm{~s})$.

\section{Preparation and characterization of the complex $f a c-\left[\mathrm{Ru}\left(\kappa^{3} N, N^{\prime}, P-L H\right)(\mathrm{NCMe})_{3}\right]$} $\left[\mathrm{SbF}_{6}\right]_{2}(\mathrm{LH}=\mathrm{LH1}(f a c-4), \mathrm{LH} 2(f a c-5), \mathrm{LH3}(f a c-6))$. A solution of the complex $\left[(\mathrm{Cy}) \mathrm{Ru}\left(\kappa^{3} N, N^{\prime}, P-\mathbf{L H}\right)\right]\left[\mathrm{SbF}_{6}\right]_{2}(250.0 \mathrm{mg}, 0.209 \mathrm{mmol}$ of $\mathbf{1}, 0.207 \mathrm{mmol}$ of $\mathbf{2}$ or 0.198 mmol of 3) in $20 \mathrm{~mL}$ of $\mathrm{MeCN}$ was heated at $65^{\circ} \mathrm{C}$ for $48 \mathrm{~h}$. The resulting solution was concentrated under reduced pressure to $c a .1 \mathrm{~mL}$. The slow addition of a 70/30 mixture $\mathrm{Et}_{2} \mathrm{O} /$ pentane led to the precipitation of an orange-brown solid. The solid was washed with $\mathrm{Et}_{2} \mathrm{O}(5 \times 10 \mathrm{~mL})$ and vacuum-dried to give an analytical pure compound. Yield: $f a c-4,161.8 \mathrm{mg}(65 \%) ; f a c-5,166.7 \mathrm{mg}(67 \%) ; f a c-6,200.6 \mathrm{mg}(81 \%)$.

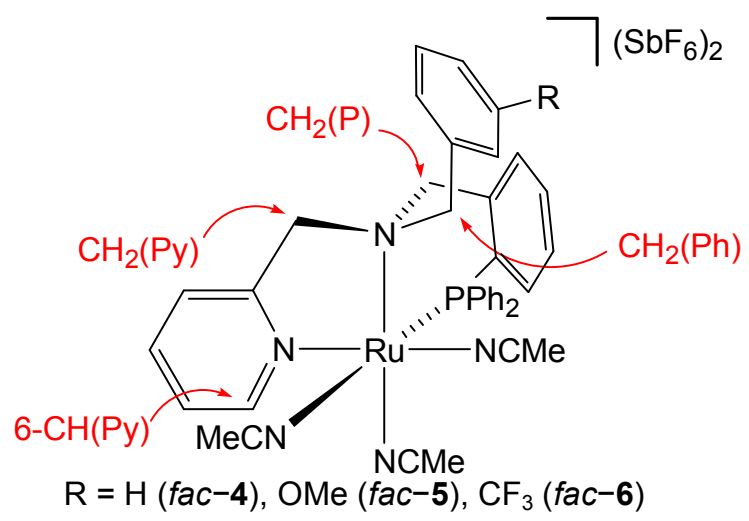

Compound fac-4. Anal. Calcd. for $\mathrm{C}_{38} \mathrm{H}_{38} \mathrm{~F}_{12} \mathrm{~N}_{5} \mathrm{PRuSb}_{2}$ : C, 39.07; H, 3.28; N, 5.99. Found: $\mathrm{C}, \quad 38.86 ; \quad \mathrm{H}, \quad 3.17 ; \mathrm{N}, \quad$ 5.79. HRMS ( $\mu$-TOF): $\mathrm{C}_{38} \mathrm{H}_{38} \mathrm{~F}_{12} \mathrm{~N}_{5} \mathrm{PRuSb}_{2}$ $\left[\mathrm{M}-\mathrm{NCMe}-\mathrm{SbF}_{6}\right]^{+}$: calc. 891.0591, found 891.0619. ${ }^{1} \mathrm{H} \mathrm{NMR}\left(400.16 \mathrm{MHz}, \mathrm{CD}_{2} \mathrm{Cl}_{2}\right.$, $R T$, ppm): $\delta=8.49(\mathrm{~d}, J=5.6 \mathrm{~Hz}, 1 \mathrm{H}, 6-\mathrm{CH}(\mathrm{Py})), 7.82-6.85\left(\mathrm{~m}, 22 \mathrm{H}, \mathrm{H}_{\mathrm{Ar}}\right), 4.66(\mathrm{~d}, J=$ 15.6 Hz, 1H, $\left.\mathrm{CH}_{2}(\mathrm{Py})\right), 4.40$ (d, $\left.J=13.9 \mathrm{~Hz}, 1 \mathrm{H}, \mathrm{CH}_{2}(\mathrm{Ph})\right), 4.02$ (dd, $J=14.0,2.3 \mathrm{~Hz}$, $\left.1 \mathrm{H}, \mathrm{CH}_{2}(\mathrm{P})\right), 4.01\left(\mathrm{~d}, J=13.9 \mathrm{~Hz}, 1 \mathrm{H}, \mathrm{CH}_{2}(\mathrm{Ph})\right), 3.68\left(\mathrm{~d}, J=15.6 \mathrm{~Hz}, 1 \mathrm{H}, \mathrm{CH}_{2}(\mathrm{Py})\right)$, $3.56\left(\mathrm{~d}, J=13.9 \mathrm{~Hz}, 1 \mathrm{H}, \mathrm{CH}_{2}(\mathrm{P})\right), 2.55$ (s, 3H, CNMe), 2.45 (s, 3H, CNMe), and 2.42 (s, 3H, CNMe). $\left.{ }^{13} C_{\{}{ }^{1} H\right\} N M R\left(100.62 M H z, C D_{2} C l, R T, p p m\right): \delta=159.51$ (s, 2- 
C(Py)), 154.08 (s, 6-CH(Py)), 137.98 (s, CH(Ar)), 137.90 (d, $J=16.2 \mathrm{~Hz}, 2-\mathrm{C}(\mathrm{PhP})$ ), $134.69(\mathrm{~d}, J=9.8 \mathrm{~Hz}, 2 \mathrm{C}, \mathrm{CH}(\mathrm{Ar})), 133.66(\mathrm{~d}, J=9.0 \mathrm{~Hz}, \mathrm{CH}(\mathrm{Ar})), 132.51$ (s, 2C, CH(Ar)), 132.43 (d, $J=9.8 \mathrm{~Hz}, 2 \mathrm{C}, \mathrm{CH}(\mathrm{Ar})), 132.15$ (brs, 2C, $\mathrm{CH}(\mathrm{Ar})$ ), 131.94 (brs, CH(Ar)), 130.90 (brs, CH(Ar)), 130.41 (d, $J=7.3 \mathrm{~Hz}, \mathrm{CH}(\mathrm{Ar})), 129.85$ (s, 1-C(Ph)), 129.72 (brs, $\mathrm{CH}(\mathrm{Ar})), 129.12$ (d, $J=9.8 \mathrm{~Hz}, 2 \mathrm{C}, \mathrm{CH}(\mathrm{Ar})$ ), 129.08 (s, CH(Ar)), 129.01 (d, $J=11.1 \mathrm{~Hz}, 2 \mathrm{C}, \mathrm{CH}(\mathrm{Ar})), 128.86$ (s, $\mathrm{CH}(\mathrm{Ar})), 128.33(\mathrm{~s}, \mathrm{MeCN}), 128.25$ (d, $J=$ 45.4 Hz, C(Ar)), 127.85 (s, MeCN), 127.76 (d, $J=52.4 \mathrm{~Hz}, \mathrm{C}(\mathrm{Ar})), 126.27$ (d, $J=49.3$ Hz, C(Ar)), 125.21 (d, $J=14.6 \mathrm{~Hz}, \mathrm{MeCN}), 124.78$ (s, CH(Ar)), 122.20 (s, CH(Ar)), 65.48 (s, $\left.\mathrm{CH}_{2}(\mathrm{Py})\right), 65.01\left(\mathrm{~s}, \mathrm{CH}_{2}(\mathrm{Ph})\right), 61.94$ (d, J=8.1 Hz, $\left.\mathrm{CH}_{2}(\mathrm{P})\right), 4.03$ (s, CNMe), 3.80 (s, CNMe), and 3.56 (s, CNMe). $\left.{ }^{31} P^{\prime l}{ }^{1} H\right\} N M R\left(161.98 \mathrm{MHz} \mathrm{CD}_{2} \mathrm{Cl}_{2}, \mathrm{RT}, \mathrm{ppm}\right): \delta$ $=52.19(s)$

Compound fac-5. Anal. Calcd. for $\mathrm{C}_{39} \mathrm{H}_{40} \mathrm{~F}_{12} \mathrm{~N}_{5} \mathrm{OPRuSb}$ : C, 39.09; H, 3.36; N, 5.84 Found: $\mathrm{C}, \quad 39.25 ; \quad \mathrm{H}, \quad 3.38 ; \quad \mathrm{N}$ 5.66. HRMS ( $\mu$-TOF): $\mathrm{C}_{39} \mathrm{H}_{40} \mathrm{~F}_{12} \mathrm{~N}_{5} \mathrm{OPRuSb}{ }_{2}$ $\left[\mathrm{M}-\mathrm{NCMe}-\mathrm{SbF}_{6}\right]^{+}$: calc. 921.0697, found 921.0697. ${ }^{1} \mathrm{H} \mathrm{NMR}\left(300.13 \mathrm{MHz}, \mathrm{CD}_{2} \mathrm{Cl}_{2}\right.$, $R T$, ppm): $\delta=8.45(\mathrm{~d}, J=5.3 \mathrm{~Hz}, 1 \mathrm{H}, 6-\mathrm{CH}(\mathrm{Py})), 7.67-6.85\left(\mathrm{~m}, 21 \mathrm{H}, \mathrm{H}_{\mathrm{Ar}}\right), 4.58(\mathrm{~d}, J=$ $\left.15.5 \mathrm{~Hz}, 1 \mathrm{H}, \mathrm{CH}_{2}(\mathrm{Py})\right), 4.32$ (d, $\left.J=13.8 \mathrm{~Hz}, 1 \mathrm{H}, \mathrm{CH}_{2}(\mathrm{Ph})\right), 4.03$ (dd, $J=13.9,2.3 \mathrm{~Hz}$, $\left.1 \mathrm{H}, \mathrm{CH}_{2}(\mathrm{P})\right), 3.95$ (d, $\left.J=13.8 \mathrm{~Hz}, 1 \mathrm{H}, \mathrm{CH}_{2}(\mathrm{Ph})\right), 3.89$ (s, 3H, OMe), 3.67 (d, $J=15.5$ $\left.\mathrm{Hz}, 1 \mathrm{H}, \mathrm{CH}_{2}(\mathrm{Py})\right), 3.56$ (d, J=13.9 Hz, 1H, $\left.\mathrm{CH}_{2}(\mathrm{P})\right), 2.52$ (s, 3H, CNMe), 2.42 (s, 3H, $\mathrm{CNMe}$ ), and 2.37 (s, 3H, CNMe). ${ }^{13} C_{\left\{{ }^{l} H\right\}} \mathrm{NMR}\left(75.48 \mathrm{MHz}, \mathrm{CD}_{2} \mathrm{Cl}_{2}, \mathrm{RT}, \mathrm{ppm}\right): \delta=$ 160.88 (s, C(OMe)), 160.33 (s, 2-C(Py)), 154.87 (s, 6-CH(Py)), 138.01 (s, CH(Ar)), $137.95(\mathrm{~d}, J=14.8 \mathrm{~Hz}, 2-\mathrm{C}(\mathrm{PhP})), 134.58(\mathrm{~d}, J=10.2 \mathrm{~Hz}, 2 \mathrm{C}, \mathrm{CH}(\mathrm{Ar})), 133.54$ (d, $J=$ 9.1 Hz, CH(Ar)), 132.40 (d, $J=9.4 \mathrm{~Hz}, 2 \mathrm{C}, \mathrm{CH}(\mathrm{Ar})$ ), 132.26 (brs, $\mathrm{CH}(\mathrm{Ar})$ ), 132.07 (brs, $\mathrm{CH}(\mathrm{Ar})$ ), 131.93 (brs, $\mathrm{CH}(\mathrm{Ar})$ ), 131.17 (s, 1-C(Ph)), 130.89 (brs, $\mathrm{CH}(\mathrm{Ar})$ ), 130.35 (d, $J=7.4 \mathrm{~Hz}, \mathrm{CH}(\mathrm{Ar})), 130.14$ (s, CH(Ar)), 129.10 (d, $J=10.2 \mathrm{~Hz}, 2 \mathrm{C}, \mathrm{CH}(\mathrm{Ar})$ ), $128.88(\mathrm{~d}, J=10.0 \mathrm{~Hz}, 2 \mathrm{C}, \mathrm{CH}(\mathrm{Ar})), 128.30(\mathrm{~s}, \mathrm{MeCN}), 128.06(\mathrm{~d}, J=45.6 \mathrm{~Hz}$, 
C(Ar)), 127.82 (d, $J=52.9 \mathrm{~Hz}, \mathrm{C}(\mathrm{Ar})), 127.79(\mathrm{~s}, \mathrm{MeCN}), 126.23$ (d, $J=48.8 \mathrm{~Hz}$, C(Ar)), $125.14(\mathrm{~d}, J=14.0 \mathrm{~Hz}, \mathrm{MeCN}), 124.79$ (s, CH(Ar)), 124.55 (s, CH(Ar)), 122.16 (s, CH(Ar)), 118.35 (s, $\mathrm{CH}(\mathrm{Ar})), 114.78$ (s, $\mathrm{CH}(\mathrm{Ar})), 66.26$ (s, $\left.\mathrm{CH}_{2}(\mathrm{Py})\right), 62.83$ (d, $\left.J=7.6 \mathrm{~Hz}, \mathrm{CH}_{2}(\mathrm{P})\right), 66.00\left(\mathrm{~s}, \mathrm{CH}_{2}(\mathrm{Ph})\right), 56.27$ (s, OMe), 4.90 (s, CNMe), 4.66 (s, $\mathrm{CNMe}$ ), and 4.43 (s, CNMe). ${ }^{31} \mathrm{P}\left\{{ }^{1} \mathrm{H}\right\} \mathrm{NMR}\left(121.42 \mathrm{MHz}, \mathrm{CD}_{2} \mathrm{Cl}_{2}, \mathrm{RT}, \mathrm{ppm}\right): \delta=52.11$ (s).

Compound fac-6. Anal. Calcd. for $\mathrm{C}_{39} \mathrm{H}_{37} \mathrm{~F}_{15} \mathrm{~N}_{5} \mathrm{PRuSb}_{2}$ : C, 37.89; H, 3.02; N, 5.66. Found: $\mathrm{C}, \quad 38.13 ; \quad \mathrm{H}, \quad 3.16 ; \quad \mathrm{N}, \quad$ 5.80. HRMS ( $\mu$-TOF): $\mathrm{C}_{39} \mathrm{H}_{37} \mathrm{~F}_{15} \mathrm{~N}_{5} \mathrm{PRuSb}_{2}$ $\left[\mathrm{M}-\mathrm{NCMe}-\mathrm{SbF}_{6}\right]^{+}$: calc. 959.0465, found 959.0423. ${ }^{1} \mathrm{H} \mathrm{NMR}\left(400.16 \mathrm{MHz}, \mathrm{CD}_{2} \mathrm{Cl}_{2}\right.$, $R T, p p m): \delta=8.40(\mathrm{~d}, J=5.6 \mathrm{~Hz}, 1 \mathrm{H}, 6-\mathrm{CH}(\mathrm{Py})), 7.87-6.69\left(\mathrm{~m}, 21 \mathrm{H}, \mathrm{H}_{\mathrm{Ar}}\right), 4.63(\mathrm{~d}, J=$ $\left.15.4 \mathrm{~Hz}, 1 \mathrm{H}, \mathrm{CH}_{2}(\mathrm{Py})\right), 4.43$ (d, $\left.J=14.0 \mathrm{~Hz}, 1 \mathrm{H}, \mathrm{CH}_{2}(\mathrm{Ph})\right), 3.98$ (d, $J=14.0 \mathrm{~Hz}, 1 \mathrm{H}$, $\left.\mathrm{CH}_{2}(\mathrm{Ph})\right), 3.85$ (brd, $\left.J=13.4 \mathrm{~Hz}, 1 \mathrm{H}, \mathrm{CH}_{2}(\mathrm{P})\right), 3.69$ (d, $\left.J=15.4 \mathrm{~Hz}, 1 \mathrm{H}, \mathrm{CH}_{2}(\mathrm{Py})\right), 3.46$ (brd, $\left.J=13.6 \mathrm{~Hz}, 1 \mathrm{H}, \mathrm{CH}_{2}(\mathrm{P})\right), 2.47$ (s, 3H, CNMe), 2.40 (s, 3H, CNMe), and 2.35 (s, $\left.3 \mathrm{H}, \mathrm{CNMe}) .{ }^{13} \mathrm{C}_{\{}{ }^{1} \mathrm{H}\right\} \mathrm{NMR}\left(100.62 \mathrm{MHz}, \mathrm{CD}_{2} \mathrm{Cl}_{2}, \mathrm{RT}, \mathrm{ppm}\right): \delta=159.18$ (s, 2-C(Py)), 154.12 (s, 6-CH(Py)), 138.04 (s, CH(Ar)), 137.42 (d, J = 15.2 Hz, 2-C(PhP)), 136.15 (s, $\mathrm{CH}(\mathrm{Ar})), 134.75$ (d, $J=9.5 \mathrm{~Hz}, 2 \mathrm{C}, \mathrm{CH}(\mathrm{Ar})), 133.55$ (d, $J=9.1 \mathrm{~Hz}, \mathrm{CH}(\mathrm{Ar})), 132.35$ (d, $J=9.9 \mathrm{~Hz}, 2 \mathrm{C}, \mathrm{CH}(\mathrm{Ar})$ ), 132.18 (brs, 2C, CH(Ar)), 132.02 (brs, $\mathrm{CH}(\mathrm{Ar})$ ), 130.92 (s,


129.36 (brs, $\mathrm{CH}(\mathrm{Ar})$ ), 129.14 (d, $J=10.2 \mathrm{~Hz}, 2 \mathrm{C}, \mathrm{CH}(\mathrm{Ar})$ ), 129.06 (brs, $\mathrm{CH}(\mathrm{Ar})$ ), $128.93(\mathrm{~d}, J=10.2 \mathrm{~Hz}, 2 \mathrm{C}, \mathrm{CH}(\mathrm{Ar})), 128.25$ (d, $J=46.3 \mathrm{~Hz}, \mathrm{C}(\mathrm{Ar})), 127.98$ (s, $\mathrm{Me} C \mathrm{~N}), 127.82(\mathrm{~s}, \mathrm{MeCN}), 127.55$ (d, $J=53.5 \mathrm{~Hz}, \mathrm{C}(\mathrm{Ar})), 126.50$ (brs, $\mathrm{CH}(\mathrm{Ar})$ ), $126.21(\mathrm{~d}, J=48.5 \mathrm{~Hz}, \mathrm{C}(\mathrm{Ar})), 125.45$ (d, $J=14.7 \mathrm{~Hz}, \mathrm{MeCN}), 124.82$ (s, CH(Ar)), 123.95 (q, $\left.J=272.7 \mathrm{~Hz}, \mathrm{CF}_{3}\right), 122.32$ (s, CH(Ar)), 65.70 (s, $\left.\mathrm{CH}_{2}(\mathrm{Py})\right), 64.33$ (s, $\left.\mathrm{CH}_{2}(\mathrm{Ph})\right), 61.99\left(\mathrm{~d}, J=8.1 \mathrm{~Hz}, \mathrm{CH}_{2}(\mathrm{P})\right), 4.05$ (s, CNMe), 3.80 (s, CNMe), and 3.52 (s, 
$\left.\mathrm{CNMe}) .{ }^{19} \mathrm{~F}^{1}{ }^{1} \mathrm{H}\right\} \mathrm{NMR}\left(282.33 \mathrm{MHz}, \mathrm{CD}_{2} \mathrm{Cl} 2, \mathrm{RT}, \mathrm{ppm}\right): \delta=-62.86$ (s). ${ }^{31} \mathrm{P}\left\{{ }^{1} \mathrm{H}\right\} \mathrm{NMR}$ (161.98 MHz, $\left.\mathrm{CD}_{2} \mathrm{Cl}_{2}, \mathrm{RT}, \mathrm{ppm}\right): \delta=52.04$ (s).

\section{Preparation and characterization of the complex $m e r-\left[\mathrm{Ru}\left(\kappa^{3} N, N^{\prime}, P-\mathrm{LH}\right)(\mathrm{NCMe})_{3}\right]$} $\left[\mathrm{SbF}_{6}\right]_{2}(\mathrm{LH}=\mathrm{LH} 1($ mer-4), LH2 (mer-5), LH3 (mer-6)). A solution of the complex $f a c^{-}\left[\mathrm{Ru}\left(\kappa^{3} N, N^{\prime}, P-\mathbf{L H}\right)(\mathrm{NCMe})_{3}\right]\left[\mathrm{SbF}_{6}\right]_{2}(200.0 \mathrm{mg}, 0.169 \mathrm{mmol}$ of $f a c-4,0.167 \mathrm{mmol}$ of $f a c^{-5}$ or $0.160 \mathrm{mmol}$ of $\left.f a c^{-6}\right)$ in $20 \mathrm{~mL}$ of $\mathrm{MeOH}$ was refluxed for $48 \mathrm{~h}$. The resulting solution was concentrated under reduced pressure to $c a .1 \mathrm{~mL}$. The slow addition of a $70 / 30$ mixture $\mathrm{Et}_{2} \mathrm{O}$ /pentane led to the precipitation of an orange-brown solid. The solid was washed with $\mathrm{Et}_{2} \mathrm{O}(2 \times 10 \mathrm{~mL})$ and vacuum-dried to give analytical and spectroscopically pure compounds mer-4 and mer-5. A 60/40, fac $-\mathbf{6} / \mathrm{mer}^{-6} \mathbf{6}$ molar ratio mixture was recovered for complex 6. Yield: $m e r-4,170.4 \mathrm{mg}(85 \%)$; $m e r-5$, $176.2 \mathrm{mg}(88 \%)$ Crystals of $m e r-\mathbf{5}$ suitable for X-ray analysis were obtained by crystallization from $\mathrm{CH}_{2} \mathrm{Cl}_{2} / \mathrm{Et}_{2} \mathrm{O}$ solutions.

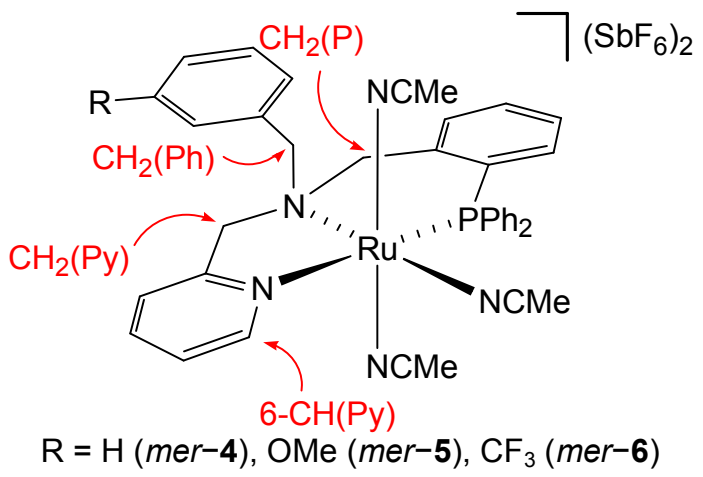

Compound mer-4. Anal. Calcd. for $\mathrm{C}_{38} \mathrm{H}_{38} \mathrm{~F}_{12} \mathrm{~N}_{5} \mathrm{PRuSb}_{2}$ : C, 39.07; H, 3.28; N, 5.99. Found: $\mathrm{C}, \quad 39.27 ; \mathrm{H}, \quad 3.44 ; \quad \mathrm{N}, \quad$ 5.89. HRMS ( $\mu$-TOF): $\mathrm{C}_{38} \mathrm{H}_{38} \mathrm{~F}_{12} \mathrm{~N}_{5} \mathrm{PRuSb}_{2}$ $\left[\mathrm{M}-\mathrm{NCMe}-\mathrm{SbF}_{6}\right]^{+}$: calc. 891.0591, found 891.0592. ${ }^{1} \mathrm{H} \mathrm{NMR}\left(500.13 \mathrm{MHz}, \mathrm{CD}_{2} \mathrm{Cl}_{2}\right.$, $R T, p p m): \delta=9.14(\mathrm{~m}, 1 \mathrm{H}, 6-\mathrm{CH}(\mathrm{Py})), 8.22-7.01\left(\mathrm{~m}, 22 \mathrm{H}, \mathrm{H}_{\mathrm{Ar}}\right), 4.45(\mathrm{~d}, J=16.3 \mathrm{~Hz}$, $\left.1 \mathrm{H}, \mathrm{CH}_{2}(\mathrm{Py})\right), 4.19$ (d, $\left.J=16.3 \mathrm{~Hz}, 1 \mathrm{H}, \mathrm{CH}_{2}(\mathrm{Py})\right), 4.06\left(\mathrm{~d}, J=14.2 \mathrm{~Hz}, 1 \mathrm{H}, \mathrm{CH}_{2}(\mathrm{P})\right)$, $3.95\left(\mathrm{dd}, J=14.2,2.2 \mathrm{~Hz}, 1 \mathrm{H}, \mathrm{CH}_{2}(\mathrm{P})\right), 3.71\left(\mathrm{~d}, J=13.9 \mathrm{~Hz}, 1 \mathrm{H}, \mathrm{CH}_{2}(\mathrm{Ph})\right), 3.44$ (d, $J=$ 
$\left.13.9 \mathrm{~Hz}, 1 \mathrm{H}, \mathrm{CH}_{2}(\mathrm{Ph})\right), 2.55$ (s, 3H, CNMe), 2.22 (s, 3H, CNMe), and 1.81 (s, 3H, CNMe). $\left.{ }^{13} C_{\{}{ }^{1} H\right\} N M R\left(125.77 \mathrm{MHz}, \mathrm{CD}_{2} \mathrm{Cl}_{2}, \mathrm{RT}, \mathrm{ppm}\right): \delta=157.35$ (s, 2-C(Py)), 152.14 (s, 6-CH(Py)), 139.85 (s, CH(Ar)), 139.92 (d, $J=17.8$ Hz, 2-C(PhP)), 136.63 (brs, $\mathrm{CH}(\mathrm{Ar})), 135.20$ (d, $J=9.7 \mathrm{~Hz}, \mathrm{CH}(\mathrm{Ar})), 132.91$ (d, $J=10.0 \mathrm{~Hz}, 2 \mathrm{C}, \mathrm{CH}(\mathrm{Ar})$ ), $132.63(\mathrm{~d}, J=9.7 \mathrm{~Hz}, 2 \mathrm{C}, \mathrm{CH}(\mathrm{Ar})), 132.62$ (d, $J=2.1 \mathrm{~Hz}, \mathrm{CH}(\mathrm{Ar})), 132.24$ (s, 2C, CH(Ar)), 131.30 (d, $J=2.4 \mathrm{~Hz}, \mathrm{CH}(\mathrm{Ar})), 131.05$ (d, $J=2.4 \mathrm{~Hz}, \mathrm{CH}(\mathrm{Ar})), 130.44$ (d, $J$ $=7.0 \mathrm{~Hz}, \mathrm{CH}(\mathrm{Ar})), 129.89$ (s, CH(Ar)), 129.73 (d, $J=48.4 \mathrm{~Hz}, \mathrm{C}(\mathrm{Ar})), 129.41$ (d, $J=$ 46.0 Hz, C(Ar)), 129.30 (d, $J=9.8 \mathrm{~Hz}, 2 \mathrm{C}, \mathrm{CH}(\mathrm{Ar})), 129.22$ (s, 1-C(Ph)), 128.95 (s, 2C, $\mathrm{CH}(\mathrm{Ar})$ ), 128.84 (d, $J=10.0 \mathrm{~Hz}, 2 \mathrm{C}, \mathrm{CH}(\mathrm{Ar})), 127.83$ (s, MeCN), 127.59 (s, $\mathrm{MeCN}), 126.51$ (s, MeCN), 126.26 (d, $J=2.2 \mathrm{~Hz}, \mathrm{CH}(\mathrm{Ar})), 125.64$ (d, $J=45.9 \mathrm{~Hz}$, C(Ar)), 123.700 (d, $J=2.1 \mathrm{~Hz}, \mathrm{CH}(\mathrm{Ar})), 64.41$ (s, $\left.\mathrm{CH}_{2}(\mathrm{Py})\right), 63.04$ (d, $J=6.2 \mathrm{~Hz}$, $\left.\mathrm{CH}_{2}(\mathrm{P})\right), 61.27$ (s, $\mathrm{CH}_{2}(\mathrm{Ph})$ ), 4.21 (s, CNMe), 3.93 (s, CNMe), and 3.42 (s, CNMe). ${ }^{31} P\left\{{ }^{l} H\right\} N M R\left(202.46 \mathrm{MHz}, \mathrm{CD}_{2} \mathrm{Cl}_{2}, \mathrm{RT}, \mathrm{ppm}\right): \delta=50.80(\mathrm{~s})$.

Compound mer-5. Anal. Calcd. for $\mathrm{C}_{39} \mathrm{H}_{40} \mathrm{~F}_{12} \mathrm{~N}_{5} \mathrm{OPRuSb}_{2}$ : C, 39.09; H, 3.36; N, 5.84 Found: $\mathrm{C}, 39.23 ; \mathrm{H}, 3.44 ; \mathrm{N}$ 5.89. HRMS ( $\mu$-TOF): $\mathrm{C}_{39} \mathrm{H}_{40} \mathrm{~F}_{12} \mathrm{~N}_{5} \mathrm{OPRuSb}_{2}$ $\left[\mathrm{M}-\mathrm{SbF}_{6}\right]^{+}$: calc. 962.0963 , found $962.0925 .{ }^{1} \mathrm{H} \mathrm{NMR}\left(300.13 \mathrm{MHz}, \mathrm{CD}_{2} \mathrm{Cl}_{2}, \mathrm{RT}, \mathrm{ppm}\right)$ : $\delta=9.12(\mathrm{~m}, 1 \mathrm{H}, 6-\mathrm{CH}(\mathrm{Py})), 8.19-6.55\left(\mathrm{~m}, 21 \mathrm{H}, \mathrm{H}_{\mathrm{Ar}}\right), 4.49(\mathrm{~d}, J=16.1 \mathrm{~Hz}, 1 \mathrm{H}$, $\left.\mathrm{CH}_{2}(\mathrm{Py})\right), 4.19$ (d, $\left.J=16.1 \mathrm{~Hz}, 1 \mathrm{H}, \mathrm{CH}_{2}(\mathrm{Py})\right), 4.07$ (d, $\left.J=14.0 \mathrm{~Hz}, 1 \mathrm{H}, \mathrm{CH}_{2}(\mathrm{P})\right), 3.98$ (dd, $\left.J=14.0,2.3 \mathrm{~Hz}, 1 \mathrm{H}, \mathrm{CH}_{2}(\mathrm{P})\right), 3.83$ (s, 3H, OMe), 3.68 (d, $J=13.9 \mathrm{~Hz}, 1 \mathrm{H}$, $\left.\mathrm{CH}_{2}(\mathrm{Ph})\right), 3.41\left(\mathrm{~d}, J=13.9 \mathrm{~Hz}, 1 \mathrm{H}, \mathrm{CH}_{2}(\mathrm{Ph})\right), 2.54$ (s, 3H, CNMe), 2.21 (s, 3H, $\mathrm{CNMe}$ ), and $\left.1.81(\mathrm{~s}, 3 \mathrm{H}, \mathrm{CNMe}) .{ }^{13} \mathrm{C}_{\{}{ }^{1} \mathrm{H}\right\} \mathrm{NMR}\left(75.48 \mathrm{MHz}, \mathrm{CD}_{2} \mathrm{Cl}_{2}, \mathrm{RT}, \mathrm{ppm}\right): \delta=$ 160.88 (s, C(OMe)), 160.33 (s, 2-C(Py)), 154.87 (s, 6-CH(Py)), 139.94 (d, J = 16.8 Hz, 2-C(PhP)), 139.87 (s, CH(Ar)), 135.22 (d, $J=9.8$ Hz, CH(Ar)), 134.68 (s, CH(Ar)), 132.84 (d, $J=9.9 \mathrm{~Hz}, 2 \mathrm{C}, \mathrm{CH}(\mathrm{Ar})), 132.62$ (d, $J=9.8 \mathrm{~Hz}, 2 \mathrm{C}, \mathrm{CH}(\mathrm{Ar})), 132.49$ (brs, CH(Ar)), 131.23 (brs, $\mathrm{CH}(\mathrm{Ar})), 131.02$ (brs, $\mathrm{CH}(\mathrm{Ar})$ ), 130.56 (s, 1-C(Ph)), 130.45 (d, J 
= 6.7 Hz, CH(Ar)), $130.04(\mathrm{~d}, J=38.0 \mathrm{~Hz}, \mathrm{C}(\mathrm{Ar})), 129.95$ (s, CH(Ar)), 129.29 (d, $J=$ $46.4 \mathrm{~Hz}, \mathrm{C}(\mathrm{Ar})), 129.28(\mathrm{~d}, J=10.1 \mathrm{~Hz}, 2 \mathrm{C}, \mathrm{CH}(\mathrm{Ar})), 128.81(\mathrm{~d}, J=9.8 \mathrm{~Hz}, 2 \mathrm{C}$, $\mathrm{CH}(\mathrm{Ar})), 128.30$ (s, MeCN), 127.41 (s, MeCN), 126.22 (s, $\mathrm{CH}(\mathrm{Ar})), 125.63$ (d, $J=46.3$ Hz, C(Ar)), 126.08 (s, MeCN), 124.21 (s, CH(Ar)), 123.62 (s, CH(Ar)), 118.10 (s, $\mathrm{CH}(\mathrm{Ar})), 115.04$ (s, $\mathrm{CH}(\mathrm{Ar})), 66.00$ (s, $\left.\mathrm{CH}_{2}(\mathrm{Ph})\right), 66.26$ (s, $\left.\mathrm{CH}_{2}(\mathrm{Py})\right), 62.83$ (d, J = 7.6 $\left.\mathrm{Hz}, \mathrm{CH}_{2}(\mathrm{P})\right), 56.27$ (s, OMe), 4.90 (s, CNMe), 4.66 (s, CNMe), and 4.43 (s, CNMe). ${ }^{31} P\left\{{ }^{l} H\right\} N M R\left(121.42 \mathrm{MHz}, \mathrm{CD}_{2} \mathrm{Cl}_{2}, \mathrm{RT}, \mathrm{ppm}\right): \delta=50.80$ (s).

Compound $m e r-6$ (characterized in a $m e r-6 / f a c-6,40 / 60$ molar ratio mixture). ${ }^{1} H$ $\operatorname{NMR}\left(500.13 \mathrm{MHz}, \mathrm{CD}_{2} \mathrm{Cl}_{2}, \mathrm{RT}, \mathrm{ppm}\right): \delta=9.19(\mathrm{~m}, 1 \mathrm{H}, 6-\mathrm{CH}(\mathrm{Py})), 8.26-6.78(\mathrm{~m}, 21 \mathrm{H}$, $\left.\mathrm{H}_{\mathrm{Ar}}\right), 4.44\left(\mathrm{~d}, J=16.3 \mathrm{~Hz}, 1 \mathrm{H}, \mathrm{CH}_{2}(\mathrm{Py})\right), 4.33$ (d, $\left.J=16.3 \mathrm{~Hz}, 1 \mathrm{H}, \mathrm{CH}_{2}(\mathrm{Py})\right), 4.15$ (d, $J$ $\left.=14.1 \mathrm{~Hz}, 1 \mathrm{H}, \mathrm{CH}_{2}(\mathrm{P})\right), 3.93\left(\mathrm{~m}, 1 \mathrm{H}, \mathrm{CH}_{2}(\mathrm{P})\right), 3.84\left(\mathrm{~d}, J=14.0 \mathrm{~Hz}, 1 \mathrm{H}, \mathrm{CH}_{2}(\mathrm{Ph})\right), 3.55$ (d, $\left.J=10.0 \mathrm{~Hz}, 1 \mathrm{H}, \mathrm{CH}_{2}(\mathrm{Ph})\right), 2.60$ (s, 3H, CNMe), 2.27 (s, 3H, CNMe), and 1.87 (s, $\left.3 \mathrm{H}, \mathrm{CNMe}) .{ }^{13} \mathrm{C}_{\{}{ }^{1} \mathrm{H}\right\} \mathrm{NMR}\left(125.77 \mathrm{MHz}, \mathrm{CD}_{2} \mathrm{Cl}_{2}, \mathrm{RT}, \mathrm{ppm}\right): \delta=156.96$ (s, 2-C(Py)), 152.28 (s, 6-CH(Py)), 140.05 (s, CH(Ar)), 139.52 (d, $J=17.7$ Hz, 2-C(PhP)), 135.7$121.5\left(\mathrm{~m}, 26 \mathrm{C}, \mathrm{Ar}, \mathrm{CF}_{3}\right), 128.08(\mathrm{~s}, \mathrm{MeCN}), 127.74(\mathrm{~s}, \mathrm{MeCN}), 126.68(\mathrm{~s}, \mathrm{MeCN})$, $64.48\left(\mathrm{~s}, \mathrm{CH}_{2}(\mathrm{Py})\right), 63.18\left(\mathrm{~d}, J=6.1 \mathrm{~Hz}, \mathrm{CH}_{2}(\mathrm{P})\right), 60.52\left(\mathrm{~s}, \mathrm{CH}_{2}(\mathrm{Ph})\right), 4.15(\mathrm{~s}, \mathrm{CNMe})$, 3.86 (s, CNMe), and 3.39 (s, CNMe). $\left.{ }^{19} \mathrm{~F}{ }^{1} \mathrm{H}\right\} \mathrm{NMR}\left(282.33 \mathrm{MHz}, \mathrm{CD}_{2} \mathrm{Cl}_{2}, \mathrm{RT}, \mathrm{ppm}\right): \delta$ $=-62.74(\mathrm{~s}) .{ }^{31} P\left\{{ }^{1} H\right\} N M R\left(202.46 \mathrm{MHz}, \mathrm{CD}_{2} \mathrm{Cl}_{2}, \mathrm{RT}, \mathrm{ppm}\right): \delta=50.73(\mathrm{~s})$.

\section{Preparation and characterization of the complex $\left[\mathrm{RuCl}_{2}\left(\mathrm{PPh}_{3}\right)\left(\kappa^{3} N, N^{\prime}, P-\mathrm{LH1}\right)\right]$}

(7). To a suspension of $\left[\mathrm{RuCl}_{2}\left(\mathrm{PPh}_{3}\right)_{3}\right](202.5 \mathrm{mg}, 0.212 \mathrm{mmol})$ in $20 \mathrm{~mL}$ of tertbutanol, $100.0 \mathrm{mg}(0.212 \mathrm{mmol})$ of LH1 were added. The resulting suspension was stirred under reflux for 4 hours. After the reaction time, the red solution was vacuumdried and the residue was recrystallized from $\mathrm{MeOH} / \mathrm{CH}_{2} \mathrm{Cl}_{2} / \mathrm{Et}_{2} \mathrm{O}$ solution, washed with $\mathrm{Et}_{2} \mathrm{O}(4 \times 10 \mathrm{~mL})$ and vacuum-dried to give an analytical pure compound. Yield: $185.7 \mathrm{mg}\left(97 \%\right.$ ). Anal. Calcd for $\mathrm{C}_{50} \mathrm{H}_{44} \mathrm{Cl}_{2} \mathrm{~N}_{2} \mathrm{P}_{2} \mathrm{Ru} \cdot \mathrm{CH}_{2} \mathrm{Cl}_{2}$ : C, 61.77; H, 4.67; N, 2.82. 
Found: C, 61.73; H, 4.67; N, 2.90. HRMS ( $\mu$-TOF): $\mathrm{C}_{50} \mathrm{H}_{44} \mathrm{Cl}_{2} \mathrm{~N}_{2} \mathrm{P}_{2} \mathrm{Ru}[\mathrm{M}-\mathrm{Cl}]^{+}$: calc. 871.1717, found 871.1764.

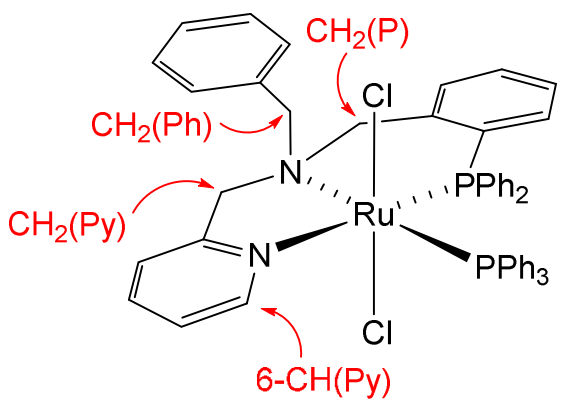

7

${ }^{1} H$ NMR (500.13 MHz, $\left.C D_{2} C l_{2}, R T, p p m\right): \delta=8.63(\mathrm{~m}, 1 \mathrm{H}, 6-\mathrm{CH}(\mathrm{Py})), 8.22-7.01(\mathrm{~m}$, 37H, $\left.\mathrm{H}_{\mathrm{Ar}}\right), 6.08$ (brd, $\left.J=14.5 \mathrm{~Hz}, 1 \mathrm{H}, \mathrm{CH}_{2}(\mathrm{Py})\right), 5.17\left(\mathrm{~d}, J=12.7 \mathrm{~Hz}, 1 \mathrm{H}, \mathrm{CH}_{2}(\mathrm{P})\right)$, $4.06\left(\mathrm{dd}, J=14.5,2.6 \mathrm{~Hz}, 1 \mathrm{H}, \mathrm{CH}_{2}(\mathrm{Py})\right), 3.90\left(\mathrm{ddd}, J=12.7,4.8,2.8 \mathrm{~Hz}, 1 \mathrm{H}, \mathrm{CH}_{2}(\mathrm{P})\right)$, and $3.66\left(\mathrm{~m}, 2 \mathrm{H}, \mathrm{CH}_{2}(\mathrm{Ph})\right) .{ }^{13} C_{\left\{{ }^{1} H\right\}} \mathrm{NMR}\left(125.77 \mathrm{MHz}, \mathrm{CD}_{2} \mathrm{Cl}_{2}, \mathrm{RT}, \mathrm{ppm}\right): \delta=162.00$ (s, 2-C(Py)), 157.57 (d, $J=2.2 \mathrm{~Hz}, 6-\mathrm{CH}(\mathrm{Py})), 139.53$ (d, $J=15.3 \mathrm{~Hz}, 2-\mathrm{C}(\mathrm{PhP})$ ), 136.98-122.20 (46C, Ar), 62.73 (s, $\left.\mathrm{CH}_{2}(\mathrm{Py})\right), 61.07$ (dd, $J=5.0,1.8 \mathrm{~Hz}, \mathrm{CH}_{2}(\mathrm{P})$ ), and $57.12\left(\mathrm{~d}, J=1.1 \mathrm{~Hz}, \mathrm{CH}_{2}(\mathrm{Ph})\right) .{ }^{31} P\left\{{ }^{1} H\right\} \mathrm{NMR}\left(202.46 \mathrm{MHz}, \mathrm{CD}_{2} \mathrm{Cl}_{2}, \mathrm{RT}, \mathrm{ppm}\right): \delta=$ $43.34\left(\mathrm{~d}, J=30.7 \mathrm{~Hz}, \mathrm{PPh}_{3}\right)$ and $42.27\left(\mathrm{~d}, J=30.7 \mathrm{~Hz}, \mathrm{PPh}_{2}\right)$.

Preparation and characterization of the complexes $\left[\operatorname{RuH}(\mathrm{CO})\left(\mathrm{PPh}_{3}\right)\left(\kappa^{3} N, N^{\prime}, P-\mathbf{L H}\right)\right] \mathrm{Cl}(\mathrm{LH}=$ LH1 (8), LH2 (9), LH3 (10)). To a suspension of $\left[\mathrm{RuClH}(\mathrm{CO})\left(\mathrm{PPh}_{3}\right)_{3}\right](1.500 \mathrm{~g}, 1.57 \mathrm{mmol})$ in $40 \mathrm{~mL}$ of EtOH, $1.57 \mathrm{mmol}$ of LH (744.2 mg of LH1, $791.5 \mathrm{mg}$ of LH2 or $851.3 \mathrm{mg}$ of LH3) were added. The resulting suspension was stirred under reflux for 48 hours. After the reaction time, the solution was vacuum-dried and the residue was firstly recrystallized from $\mathrm{MeOH} / \mathrm{CH}_{2} \mathrm{Cl}_{2} / \mathrm{Et}_{2} \mathrm{O}$ solution, washed with $\mathrm{Et}_{2} \mathrm{O}(4 \times 10 \mathrm{~mL})$ and finally vacuum-dried to give an analytical pure compound. Yield: 8, $1.123 \mathrm{~g}(79 \%) ; \mathbf{9}, 1.195 \mathrm{~g}(82 \%) ; 10$, 
$1.306 \mathrm{~g}(86 \%)$. Crystals of $\mathbf{1 0}$ suitable for X-ray analysis were obtained by crystallization from $\mathrm{EtOH} / \mathrm{Et}_{2} \mathrm{O} /$ pentane solutions.

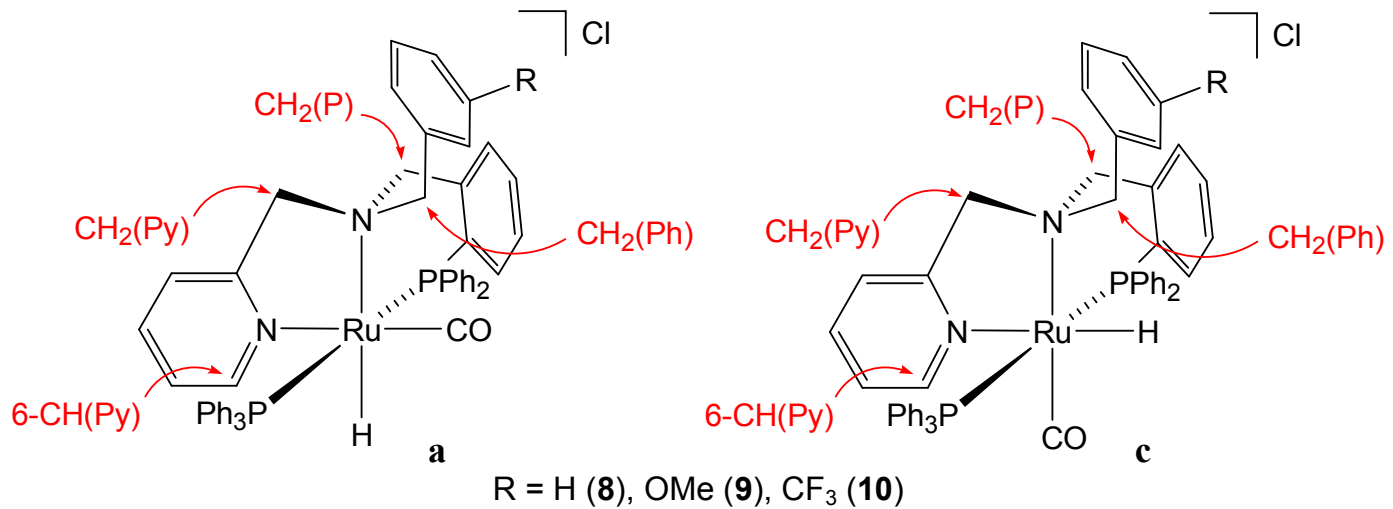

Compound 8. Anal. Calcd for $\mathrm{C}_{51} \mathrm{H}_{45} \mathrm{ClN}_{2} \mathrm{OP}_{2} \mathrm{Ru} \cdot \mathrm{CH}_{2} \mathrm{Cl}_{2}: \mathrm{C}, 63.39 ; \mathrm{H}, 4.81 ; \mathrm{N}, 2.84$.

Found: C, 63.49; H, 4.74; N, 3.01. IR $\left(\mathrm{cm}^{-1}\right): v(\mathrm{CO}) 924$ (s). HRMS ( $\left.\mu-\mathrm{TOF}\right)$ : $\mathrm{C}_{51} \mathrm{H}_{45} \mathrm{ClN}_{2} \mathrm{OP}_{2} \mathrm{Ru}[\mathrm{M}-\mathrm{Cl}]^{+}$: calc. 865.2059 , found 865.2086. The isolated solid was characterized by NMR as a mixture of isomers: at $298 \mathrm{~K}$, in $c a .98: 2(\mathbf{8 a} / \mathbf{8 c})$ and at 313 $\mathrm{K}$, in ca. $75 / 23 / 2\left(\mathbf{8 a} / \mathbf{8 a} \mathbf{a}^{\prime} / \mathbf{8 c}\right)$ molar ratio.

8a (98 \%). ${ }^{1} H N M R\left(300.13 \mathrm{MHz}, C D_{3} \mathrm{OD}, \mathrm{RT}, \mathrm{ppm}\right): \delta=8.30-6.35(38 \mathrm{H}, \mathrm{H}(\mathrm{Ar})), 4.36$ (brd, $J=13.8 \mathrm{~Hz}, 1 \mathrm{H}, \mathrm{CH}_{2}(\mathrm{Py})$ ), 4.33 (brd, $J=14.4 \mathrm{~Hz}, 1 \mathrm{H}, \mathrm{CH}_{2}(\mathrm{Py})$ ), 4.04 (brd, $J=$ $14.4 \mathrm{~Hz}, 1 \mathrm{H}, \mathrm{CH}_{2}(\mathrm{Ph})$ ), 3.99 (br, $\left.1 \mathrm{H}, \mathrm{CH}_{2}(\mathrm{P})\right), 3.77$ (brd, $J=15.0 \mathrm{~Hz}, 1 \mathrm{H}, \mathrm{CH}_{2}(\mathrm{Ph})$ ), 3.57 (brd, $J=12.4 \mathrm{~Hz}, 1 \mathrm{H}, \mathrm{CH}_{2}(\mathrm{P})$ ), and -13.33 (pt, $\left.J=22.7 \mathrm{~Hz}, \mathrm{RuH}\right) .{ }^{13} C\left\{{ }^{1} H\right\} N M R$ (75.48 MHz, $\left.C D_{3} \mathrm{OD}, R T, \mathrm{ppm}\right): \delta=204.99$ (br, CO), 158.08 (brs, 2-C(Py)), 154.77 (brs, 6-CH(Py)), 139.00-121.16 (46C, Ar), 65.61 (brs, 2C, $\mathrm{CH}_{2}(\mathrm{Py}), \mathrm{CH}_{2}(\mathrm{P})$ ), and 60.73 (br, $\left.\mathrm{CH}_{2}(\mathrm{Ph})\right) .{ }^{31} \mathrm{P}\left\{{ }^{1} H\right\} N M R\left(121.42 \mathrm{MHz}, C D_{3} \mathrm{OD}, 298 \mathrm{~K}, \mathrm{ppm}\right): \delta=41.88(\mathrm{AB}$ system, $J=255.9 \mathrm{~Hz}, \mathrm{PPh}_{3}$ ) and $40.57\left(\mathrm{AB}\right.$ system, $\left.J=255.9 \mathrm{~Hz}, \mathrm{PPh}_{2}\right)$.

8a $(75 \%) .{ }^{1} H N M R\left(500.13 \mathrm{MHz}, C D_{3} O D, 213 \mathrm{~K}, \mathrm{ppm}\right): \delta=-13.17$ (pt, $J=23.3 \mathrm{~Hz}$, RuH). ${ }^{31} P\left\{{ }^{1} H\right\} N M R\left(202.46 \mathrm{MHz}, C D_{3} \mathrm{OD}, 213, \mathrm{ppm}\right): \delta=41.62$ (AB system, $J=$ $253.5 \mathrm{~Hz}, \mathrm{PPh}_{3}$ ) and $40.84\left(\mathrm{AB}\right.$ system, $J=253.5 \mathrm{~Hz}, \mathrm{PPh}_{2}$ ). 
8a' $(23 \%) .{ }^{l} H \operatorname{NMR}\left(500.13 \mathrm{MHz}, C D_{3} O D, 213 \mathrm{~K}, \mathrm{ppm}\right): \delta=-12.82(\mathrm{dd}, J=28.2,15.6$ $\mathrm{Hz}, \mathrm{RuH}) .{ }^{31} P\left\{{ }^{1} H\right\} N M R\left(202.46 \mathrm{MHz}, \mathrm{CD}_{3} \mathrm{OD}, 213, \mathrm{ppm}\right): \delta=43.96$ (AB system, $J=$ $253.8 \mathrm{~Hz}, \mathrm{PPh}_{3}$ ) and $40.12\left(\mathrm{AB}\right.$ system, $\left.J=253.8 \mathrm{~Hz}, \mathrm{PPh}_{2}\right)$.

8c (2 \%). ${ }^{1} H N M R\left(300.13 \mathrm{MHz}, C D_{3} O D, R T, p p m\right): \delta=-11.28(\mathrm{dd}, J=23.7,18.7 \mathrm{~Hz}$, RuH). ${ }^{1} H$ NMR (500.13 MHz, $\left.C D_{3} O D, 213 \mathrm{~K}, \mathrm{ppm}\right): \delta=-11.01(\mathrm{dd}, J=23.3,18.5 \mathrm{~Hz}$, RuH). ${ }^{31} P\left\{{ }^{l} H\right\} N M R\left(202.46 \mathrm{MHz}, C D_{3} \mathrm{OD}, 213, p p m\right): \delta=43.58(\mathrm{~d}, J=256.1 \mathrm{~Hz}$, $\left.\mathrm{PPh}_{3}\right)$ and $36.78\left(\mathrm{~d}, J=256.1 \mathrm{~Hz}, \mathrm{PPh}_{2}\right)$.

Compound 9. Anal. Calcd for $\mathrm{C}_{52} \mathrm{H}_{47} \mathrm{ClN}_{2} \mathrm{O}_{2} \mathrm{P}_{2} \mathrm{Ru} \cdot \mathrm{CH}_{2} \mathrm{Cl}_{2}$ : C, 62.70; H, 4.86; N, 2.76. Found: C, 62.49; H, 4.95; N, 2.68. IR $\left(\mathrm{cm}^{-1}\right): v(\mathrm{CO}) 1925$ (s). HRMS ( $\left.\mu-\mathrm{TOF}\right)$ : $\mathrm{C}_{52} \mathrm{H}_{47} \mathrm{ClN}_{2} \mathrm{O}_{2} \mathrm{P}_{2} \mathrm{Ru}[\mathrm{M}-\mathrm{Cl}]^{+}$: calc. 895.2165, found 895.2113. The isolated solid was characterized by NMR as a mixture of isomers: at $298 \mathrm{~K}$, in $c a .97: 3(\mathbf{9 a} / \mathbf{9 c})$ and at 313 $\mathrm{K}$, in $c a .71 / 26 / 3\left(\mathbf{9 a} / \mathbf{9 a} \mathbf{a}^{\prime} / 9 \mathbf{c}\right)$ molar ratio.

9a (97 \%). ${ }^{1} H \mathrm{NMR}\left(300.13 \mathrm{MHz}, \mathrm{CD}_{3} \mathrm{OD}, \mathrm{RT}, \mathrm{ppm}\right): \delta=8.00-6.21(37 \mathrm{H}, \mathrm{H}(\mathrm{Ar})), 4.33$ (brd, $\left.J=13.7 \mathrm{~Hz}, 1 \mathrm{H}, \mathrm{CH}_{2}(\mathrm{Py})\right), 4.30$ (brd, $\left.J=14.9 \mathrm{~Hz}, 1 \mathrm{H}, \mathrm{CH}_{2}(\mathrm{Py})\right), 4.00$ (brd, $J=$ 14.1 Hz, 2H, $\left.\mathrm{CH}_{2}(\mathrm{Ph}), \mathrm{CH}_{2}(\mathrm{P})\right), 3.83$ (s, 3H, OMe), 3.81 (brd, $J=15.5 \mathrm{~Hz}, 1 \mathrm{H}$, $\left.\mathrm{CH}_{2}(\mathrm{Ph})\right), 3.58$ (br, $\left.1 \mathrm{H}, \mathrm{CH}_{2}(\mathrm{P})\right)$, and -13.34 (pt, $\left.J=22.7 \mathrm{~Hz}, \mathrm{RuH}\right) .{ }^{13} C\left\{{ }^{1} H\right\} N M R$ (75.48 MHz, $\left.C D_{3} \mathrm{OD}, R T, p p m\right): \delta=205.00$ (pt, $\left.J=16.6 \mathrm{~Hz}, \mathrm{CO}\right), 159.77$ (s, C(OMe)), 158.06 (br, 2-C(Py)), 154.67 (br, 6-CH(Py)), 138.72-113.60 (45C, Ar), 65.66 (brs, 2C, $\left.\mathrm{CH}_{2}(\mathrm{Py}), \mathrm{CH}_{2}(\mathrm{P})\right), 58.63$ (br, $\left.\mathrm{CH}_{2}(\mathrm{Ph})\right)$, and 54.56 (s, OMe). ${ }^{31} P\left\{{ }^{1} H\right\} N M R$ (121.42 $\left.M H z, C D_{3} O D, 298 K, p p m\right): \delta=41.82\left(\mathrm{AB}\right.$ system, $\left.J=255.1 \mathrm{~Hz}, \mathrm{PPh}_{3}\right)$ and $40.58(\mathrm{AB}$ system, $\left.J=255.1 \mathrm{~Hz}, \mathrm{PPh}_{2}\right)$.

9a $(71 \%) .{ }^{1} H N M R\left(500.13 \mathrm{MHz}, C D_{3} O D, 213 \mathrm{~K}, \mathrm{ppm}\right): \delta=-13.19$ (pt, $J=23.3 \mathrm{~Hz}$, RuH). ${ }^{31} P\left\{{ }^{1} H\right\} N M R\left(202.46 \mathrm{MHz}, C D_{3} O D, 213, p p m\right): \delta=41.58$ (AB system, $J=$ 254.3 Hz, $\mathrm{PPh}_{3}$ ) and $40.84\left(\mathrm{AB}\right.$ system, $J=254.3 \mathrm{~Hz}, \mathrm{PPh}_{2}$ ). 
9a' (26 \%). ${ }^{1} H \operatorname{NMR}\left(500.13 \mathrm{MHz}, \mathrm{CD}_{3} \mathrm{OD}, 213 \mathrm{~K}, \mathrm{ppm}\right): \delta=-12.83(\mathrm{dd}, J=28.6,15.7$ $\mathrm{Hz}, \mathrm{RuH}) .{ }^{31} P\left\{{ }^{1} H\right\} N M R\left(202.46 \mathrm{MHz}, C D_{3} O D, 213, p p m\right): \delta=43.91$ (AB system, $J=$ $253.5 \mathrm{~Hz}, \mathrm{PPh}_{3}$ ) and 40.25 (AB system, $J=253.5 \mathrm{~Hz}, \mathrm{PPh}_{2}$ ).

9c (3 \%). ${ }^{1} H N M R\left(300.13 \mathrm{MHz}, C D_{3} O D, R T, p p m\right): \delta=-11.29(\mathrm{dd}, J=23.7,18.8 \mathrm{~Hz}$, $\mathrm{RuH}) .{ }^{1} \mathrm{H} N M R\left(500.13 \mathrm{MHz}, C D_{3} \mathrm{OD}, 213 \mathrm{~K}, \mathrm{ppm}\right): \delta=-11.01(\mathrm{dd}, J=23.8,19.7 \mathrm{~Hz}$, $\mathrm{RuH}) .{ }^{31} P\left\{{ }^{1} H\right\} N M R\left(202.46 \mathrm{MHz}, C D_{3} \mathrm{OD}, 213, p p m\right): \delta=43.51(\mathrm{~d}, J=256.3 \mathrm{~Hz}$, $\left.\mathrm{PPh}_{3}\right)$ and $36.75\left(\mathrm{~d}, J=256.3 \mathrm{~Hz}, \mathrm{PPh}_{2}\right)$.

Compound 10. Anal. Calcd for $\mathrm{C}_{52} \mathrm{H}_{44} \mathrm{~F}_{3} \mathrm{ClN}_{2} \mathrm{OP}_{2} \mathrm{Ru} \cdot \mathrm{OH}_{2}: \mathrm{C}, 63.32 ; \mathrm{H}, 4.70 ; \mathrm{N}$, 2.84. Found: C, 63.16; H, 4.91; N, 2.52. IR ( $\left.\mathrm{cm}^{-1}\right): v(\mathrm{CO}) 929$ (s). HRMS ( $\mu$-TOF): $\mathrm{C}_{52} \mathrm{H}_{44} \mathrm{~F}_{3} \mathrm{ClN}_{2} \mathrm{OP}_{2} \mathrm{Ru}\left[\mathrm{M}-\mathrm{HPPh}_{3}\right]^{+}$: calc. 705.0624, found 705.0634. The isolated solid was characterized by NMR as a mixture of isomers: at $298 \mathrm{~K}$, in $c a .98: 2(\mathbf{1 0 a} / \mathbf{1 0 c})$ and at $313 \mathrm{~K}$, in $c a .73 / 25 / 2(\mathbf{1 0 a} / \mathbf{1 0 a} / \mathbf{1 0 c})$ molar ratio.

$10 \mathrm{a}(98 \%) .{ }^{1} H \mathrm{HMR}\left(300.13 \mathrm{MHz}, C D_{3} \mathrm{OD}, R T, p p m\right): \delta=8.25-6.26(37 \mathrm{H}, \mathrm{H}(\mathrm{Ar}))$, 4.40 (brd, $J=14.2 \mathrm{~Hz}, 1 \mathrm{H}, \mathrm{CH}_{2}(\mathrm{Py})$ ), 4.18 (pt, $J=12.5 \mathrm{~Hz}, 2 \mathrm{H}, \mathrm{CH}_{2}(\mathrm{Py}), \mathrm{CH}_{2}(\mathrm{Ph})$ ), 3.91 (br, $\left.1 \mathrm{H}, \mathrm{CH}_{2}(\mathrm{P})\right), 3.82\left(\mathrm{~d}, J=14.7 \mathrm{~Hz}, 1 \mathrm{H}, \mathrm{CH}_{2}(\mathrm{Ph})\right), 3.61\left(\mathrm{br}, 1 \mathrm{H}, \mathrm{CH}_{2}(\mathrm{P})\right)$, and -13.46 (pt, $\left.J=22.3 \mathrm{~Hz}, \mathrm{RuH}) .{ }^{13} C_{\{}{ }^{1} H\right\} N M R\left(75.48 \mathrm{MHz}, C D_{3} O D, R T, p p m\right): \delta=$ 204.94 (pt, $J=15.0$ Hz, CO), 157.59 (brs, 2-C(Py)), 154.07 (brs, 6-CH(Py)), 138.12123.88 (45C, Ar), 123.97 (q, $J=273.4 \mathrm{~Hz}, \mathrm{CF}_{3}$ ), 64.53 (brs, $2 \mathrm{C}, \mathrm{CH}_{2}(\mathrm{Py}), \mathrm{CH}_{2}(\mathrm{P})$ ), and 61.64 (br, $\left.\left.\mathrm{CH}_{2}(\mathrm{Ph})\right) .{ }^{19} \mathrm{~F}^{l}{ }^{1} H\right\}$ NMR (282.33 MHz, CD $\left.3 \mathrm{OD}, \mathrm{RT}, \mathrm{ppm}\right): \delta=-62.66$ (s). ${ }^{31} P\left\{{ }^{l} H\right\} N M R\left(121.42 \mathrm{MHz}, \mathrm{CD}_{3} \mathrm{OD}, 298 \mathrm{~K}, \mathrm{ppm}\right): \delta=41.85$ (AB system, $J=255.7$ $\mathrm{Hz}, \mathrm{PPh}_{3}$ ) and $40.52\left(\mathrm{AB}\right.$ system, $J=255.7 \mathrm{~Hz}, \mathrm{PPh}_{2}$ ).

10a (73 \%). ${ }^{1} H \operatorname{NMR}\left(500.13 \mathrm{MHz}, C D_{3} O D, 213 \mathrm{~K}, \mathrm{ppm}\right): \delta=-13.22$ (pt, $J=22.6 \mathrm{~Hz}$, $\left.\mathrm{RuH}) .{ }^{31} \mathrm{P}^{1}{ }^{1} H\right\} \operatorname{NMR}\left(202.46 \mathrm{MHz}, \mathrm{CD} \mathrm{D}_{3} \mathrm{OD}, 213, \mathrm{ppm}\right): \delta=41.64$ (AB system, $J=$ $254.3 \mathrm{~Hz}, \mathrm{PPh}_{3}$ ) and 40.75 (AB system, $\left.J=254.3 \mathrm{~Hz}, \mathrm{PPh}_{2}\right)$. 
10a' (25\%). ${ }^{1} H$ NMR (500.13 MHz, $\left.C D_{3} O D, 213 \mathrm{~K}, \mathrm{ppm}\right): \delta=-12.87$ (dd, $J=26.8$, $14.6 \mathrm{~Hz}, \mathrm{RuH}) .{ }^{31} P\left\{{ }^{1} H\right\} N M R\left(202.46 \mathrm{MHz}, C D_{3} \mathrm{OD}, 213, \mathrm{ppm}\right): \delta=43.98$ (AB system, $\left.J=253.3 \mathrm{~Hz}, \mathrm{PPh}_{3}\right)$ and $40.17\left(\mathrm{AB}\right.$ system, $\left.J=253.3 \mathrm{~Hz}, \mathrm{PPh}_{2}\right)$.

10c $(2 \%) .{ }^{1} H N M R\left(300.13 \mathrm{MHz}, C D_{3} O D, R T, p p m\right): \delta=-11.33$ (pt, $J=21.6 \mathrm{~Hz}$, $\mathrm{RuH}) .{ }^{19} \mathrm{~F}\left\{{ }^{1} H\right\} N M R\left(282.33 \mathrm{MHz}, C D_{3} \mathrm{OD}, \mathrm{RT}, \mathrm{ppm}\right): \delta=-62.76$ (s). ${ }^{1} \mathrm{H} N M R(500.13$ $\left.M H z, C D_{3} O D, 213 \mathrm{~K}, \mathrm{ppm}\right): \delta=-11.05(\mathrm{dd}, J=24.1,17.3 \mathrm{~Hz}, \mathrm{RuH}) .{ }^{31} P\left\{{ }^{1} H\right\} N M R$ (202.46 MHz, $\left.C D_{3} O D, 213, p p m\right): \delta=43.41\left(\mathrm{~d}, J=256.3 \mathrm{~Hz}, \mathrm{PPh}_{3}\right)$ and $36.90(\mathrm{~d}, J=$ 256.3 Hz, $\left.\mathrm{PPh}_{2}\right)$.

\section{Preparation and characterization of the complexes $\left[\mathrm{RuCl}(\mathrm{CO})\left(\kappa^{4} N, N^{\prime}, C, P-\mathrm{L}\right)\right](\mathrm{L}$}

= L1 (11), L2 (12), L3 (13)). Suspensions of a mixture of isomers of the complexes $\left[\mathrm{RuH}(\mathrm{CO})\left(\mathrm{PPh}_{3}\right)\left(\kappa^{3} N, N^{\prime}, P-\mathbf{L H}\right)\right] \mathrm{Cl}(500.0 \mathrm{mg}, 0.555 \mathrm{mmol}$ of $\mathbf{8}, 0.537 \mathrm{mmol}$ of $\mathbf{9}$ or $0.516 \mathrm{mmol}$ of 10) in $20 \mathrm{~mL}$ of 2-ethoxyethanol were stirred for 2 days under reflux. Then, the resulting solution was vacuum-dried and the residue was recrystallized from $\mathrm{CH}_{2} \mathrm{Cl}_{2} /$ pentane, washed with $\mathrm{Et}_{2} \mathrm{O}$ and vacuum-dried to give an analytical pure compound. Yield: 11, $290.7 \mathrm{mg}$ (82\%); 12, $257.1 \mathrm{mg}$ (72\%); 13, $293.9 \mathrm{mg}(81 \%)$. Crystals of 11-13, suitable for X-ray analysis were obtained by crystallization from $\mathrm{CH}_{2} \mathrm{Cl}_{2} /$ pentane solutions.
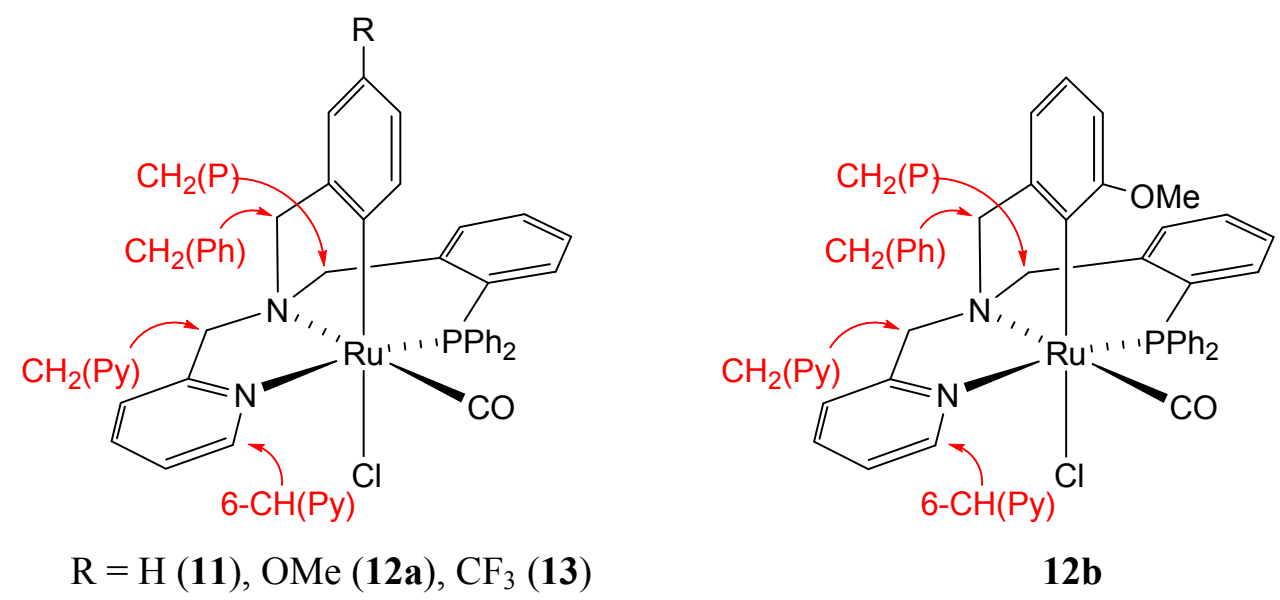

12b 
Compound 11. Anal. calcd for $\mathrm{C}_{33} \mathrm{H}_{28} \mathrm{ClN}_{2} \mathrm{OPRu}$ : C, 62.31; H, 4.44; N, 4.40. Found: C, 62.55; H, 4.64; N, 4.39. IR $\left(\mathrm{cm}^{-1}\right): \quad v(\mathrm{CO}) 1920$ (s). HRMS ( $\mu$-TOF): $\mathrm{C}_{33} \mathrm{H}_{28} \mathrm{ClN}_{2} \mathrm{OPRu}[\mathrm{M}-\mathrm{Cl}]^{+}$: calc. 601.0986, found 601.1025. ${ }^{1} \mathrm{H}$ NMR (500.13 MHz, $\left.\mathrm{CD}_{2} \mathrm{Cl}_{2}, \mathrm{RT}, \mathrm{ppm}\right): \delta=8.7$ (brptd, $\left.J=5.5,2.7 \mathrm{~Hz}, 1 \mathrm{H}, 6-\mathrm{CH}(\mathrm{Py})\right), 7.7-6.3(\mathrm{~m}, 21 \mathrm{H}$, $\mathrm{H}(\mathrm{Ar})), 5.62\left(\mathrm{~d}, J=13.1 \mathrm{~Hz}, 1 \mathrm{H}\right.$, pro- $\left.R-\mathrm{CH}_{2}(\mathrm{P})\right), 5.59(\mathrm{~d}, J=14.6 \mathrm{~Hz}, 1 \mathrm{H}$, pro- $S-$ $\left.\mathrm{CH}_{2}(\mathrm{Py})\right), 4.58\left(\mathrm{~d}, J=16.9 \mathrm{~Hz}, 1 \mathrm{H}\right.$, pro- $\left.R-\mathrm{CH}_{2}(\mathrm{Ph})\right), 4.09(\mathrm{~d}, J=14.3 \mathrm{~Hz}, 1 \mathrm{H}$, pro- $R$ $\left.\mathrm{CH}_{2}(\mathrm{Py})\right), 4.00\left(\mathrm{dd}, J=13.0,3.1 \mathrm{~Hz}, 1 \mathrm{H}, \operatorname{pro}-\mathrm{S}-\mathrm{CH}_{2}(\mathrm{P})\right)$, and $3.80(\mathrm{~d}, J=16.9 \mathrm{~Hz}, 1 \mathrm{H}$, pro- $\left.S-\mathrm{CH}_{2}(\mathrm{Ph})\right) .{ }^{13} C\left\{{ }^{1} \mathrm{H}\right\} N M R\left(125.77 \mathrm{MHz}, \mathrm{CD}_{2} \mathrm{Cl}_{2}, \mathrm{RT}, \mathrm{ppm}\right): \delta=205.14(\mathrm{~d}, J=18.2$ Hz, CO), 167.39 (d, J= 12.6 Hz, CRu), 157.79 (s, 2-C(Py)), 151.59 (s, 6-CH(Py)), 146.16 (s, 2-C(Ph)), 142.18 (d, $J=18.9$ Hz, 2-C(PhP)), 139.44 (s, CH(Ar)), 137.10 (s, CH(Ar)), 135.40 (s, CH(Ar)), 134.7 (d, $J=10.1 \mathrm{~Hz}, 2 \mathrm{C}, \mathrm{CH}(\mathrm{Ar})), 133.57$ (d, $J=8.8$ Hz, CH(Ar)), 132.81 (d, J=8.8 Hz, 2C, CH(Ar)), 131.92 (s, C(Ar), 131.55 (s, C(Ar)), $131.26(\mathrm{~d}, J=1.3 \mathrm{~Hz}, \mathrm{CH}(\mathrm{Ar})), 129.79$ (d, $J=2.5 \mathrm{~Hz}, \mathrm{CH}(\mathrm{Ar})), 129.26$ (d, $J=36.5 \mathrm{~Hz}$, C(Ar)), 128.32 (d, $J=5.8 \mathrm{~Hz}, \mathrm{CH}(\mathrm{Ar})), 128.97$ (d, $J=2.1 \mathrm{~Hz}, \mathrm{CH}(\mathrm{Ar})), 127.62$ (d, $J=$ $10.1 \mathrm{~Hz}, 2 \mathrm{C}, \mathrm{CH}(\mathrm{Ar})), 127.06$ (d, $J=9.9 \mathrm{~Hz}, 2 \mathrm{C}, \mathrm{CH}(\mathrm{Ar})), 126.05(\mathrm{~s}, \mathrm{CH}(\mathrm{Ar})), 123.96$ (d, $J=2.5 \mathrm{~Hz}, \mathrm{CH}(\mathrm{Ar})), 121.64$ (d, $J=2.5 \mathrm{~Hz}, \mathrm{CH}(\mathrm{Ar})), 120.46$ (s, CH(Ar)), 118.55 (s, $\mathrm{CH}(\mathrm{Ar})), 71.14\left(\mathrm{~s}, \mathrm{CH}_{2}(\mathrm{Py})\right), 65.96\left(\mathrm{~s}, \mathrm{CH}_{2}(\mathrm{Ph})\right)$, and $64.86\left(\mathrm{~d}, J=6.4 \mathrm{~Hz}, \mathrm{CH}_{2}(\mathrm{P})\right)$. ${ }^{31} P\left\{{ }^{l} H\right\} N M R\left(202.46 \mathrm{MHz}, \mathrm{CD}_{2} \mathrm{Cl}_{2}, \mathrm{RT}, \mathrm{ppm}\right): \delta=56.28(\mathrm{~s})$.

Compound 12a,b. The isolated solid consists of a mixture of isomers in ca. 50/50 (12a/12b) molar ratio before crystallization. By crystallization a 64/36 (12a/12b) molar ratio was obtained. Anal. calcd. for $\mathrm{C}_{34} \mathrm{H}_{30} \mathrm{ClN}_{2} \mathrm{O}_{2} \mathrm{PRu}$ : C, 61.31; H, 4.54; N, 4.20. Found: C, 61.35; H, 4.66; N, 4.09. IR ( $\left.\mathrm{cm}^{-1}\right): v(\mathrm{CO}) 1936$ (brs). HRMS ( $\mu$-TOF): $\mathrm{C}_{34} \mathrm{H}_{30} \mathrm{ClN}_{2} \mathrm{O}_{2} \mathrm{PRu}[\mathrm{M}-\mathrm{Cl}]^{+}$: calc. 631.1092, found 631.1120.

12a (64 \%). ${ }^{l} H$ NMR (500.13 MHz, $\left.C D_{2} C l_{2}, R T, p p m\right): \delta=8.72(\mathrm{ddd}, J=4.7,1.6,0.8$ Hz, 1H, 6-CH(Py)), 7.80-6.57 (m, 16H, H(Ar)), 6.55 (pt, J=7.8 Hz, 2H, H(Ar)), 6.22 
(dd, $J=9.1,2.9 \mathrm{~Hz}, 1 \mathrm{H}, \mathrm{H}(\mathrm{Ar})), 6.07$ (d, $J=2.9 \mathrm{~Hz}, 1 \mathrm{H}, \mathrm{H}(\mathrm{Ar})$ ), 4.62 (d, $J=16.8 \mathrm{~Hz}$, $1 \mathrm{H}$, pro- $\left.S-\mathrm{CH}_{2}(\mathrm{Py})\right), 4.58\left(\mathrm{~d}, J=17.0 \mathrm{~Hz}, 1 \mathrm{H}\right.$, pro- $\left.R-\mathrm{CH}_{2}(\mathrm{Ph})\right), 4.11(\mathrm{dd}, J=14.3,4.4$ $\mathrm{Hz}, 1 \mathrm{H}$, pro- $\left.R-\mathrm{CH}_{2}(\mathrm{P})\right), 4.03\left(\mathrm{ddd}, J=13.0,3.3 \mathrm{~Hz}, 1 \mathrm{H}\right.$, pro- $\left.S-\mathrm{CH}_{2}(\mathrm{P})\right), 3.86(\mathrm{~d}, J=$ $16.9 \mathrm{~Hz}, 1 \mathrm{H}$, pro- $\left.R-\mathrm{CH}_{2}(\mathrm{Py})\right), 3.81$ (d, $J=17.6 \mathrm{~Hz}, 1 \mathrm{H}$, pro- $-\mathrm{C}-\mathrm{CH}_{2}(\mathrm{Ph})$ ), and $3.26(\mathrm{~s}$, 3H, OMe). $\left.{ }^{13} C_{\{}{ }^{l} H\right\}$ NMR (125.77 MHz, $\left.\mathrm{CD}_{2} \mathrm{Cl}_{2}, \mathrm{RT}, \mathrm{ppm}\right): \delta=205.22$ (d, J=18.2 Hz, CO), 157.74 (s, 2-C(Py)), 155.56 (s, C(OMe)), 154.63 (d, J=11.3 Hz, CRu), 151.62 (s, 6-CH(Py)), 146.39 (s, 2-C(Ph)), 142.02 (d, $J=18.5$ Hz, 2-C(PhP)), 139.26 (s, CH(Ar)), 137.04 (s, CH(Ar)), 135.52 (s, CH(Ar)), 134.72 (d, $J=10.3 \mathrm{~Hz}, 2 \mathrm{C}, \mathrm{CH}(\mathrm{Ar})), 133.57$ (d, $J=9.2 \mathrm{~Hz}, 1 \mathrm{C}, \mathrm{CH}(\mathrm{Ar})), 132.86$ (d, $J=9.7 \mathrm{~Hz}, 2 \mathrm{C}, \mathrm{CH}(\mathrm{Ar})), 131.22$ (d, $J=1.6 \mathrm{~Hz}$, $\mathrm{CH}(\mathrm{Ar})), 129.74$ (d, $J=1.9 \mathrm{~Hz}, \mathrm{CH}(\mathrm{Ar})), 128.94$ (d, $J=1.8 \mathrm{~Hz}, \mathrm{CH}(\mathrm{Ar})), 128.20$ (dd, $J$ $=21.0,5.2 \mathrm{~Hz}, \mathrm{CH}(\mathrm{Ar})), 129.31(\mathrm{~d}, J=28.0 \mathrm{~Hz}, \mathrm{C}(\mathrm{Ar})), 127.61(\mathrm{~d}, J=10.0 \mathrm{~Hz}, 2 \mathrm{C}$, $\mathrm{CH}(\mathrm{Ar})), 127.04$ (d, $J=10.0 \mathrm{~Hz}, 2 \mathrm{C}, \mathrm{CH}(\mathrm{Ar})), 124.89$ (s, CH(Ar)), 123.85 (d, $J=1.8$ $\mathrm{Hz}, \mathrm{CH}(\mathrm{Ar})), 121.88$ (d, $J=3.7 \mathrm{~Hz}, \mathrm{CH}(\mathrm{Ar})), 121.61$ (d, $J=1.7 \mathrm{~Hz}, \mathrm{CH}(\mathrm{Ar})), 114.45$ (s, $\mathrm{CH}(\mathrm{Ar})$ ), 112.25 (s, $\mathrm{CH}(\mathrm{Ar})$ ), 105.53 (s, $\mathrm{CH}(\mathrm{Ar})), 71.10$ (brs, $\mathrm{CH}_{2}(\mathrm{Py})$ ), 66.08 (s, $\left.\mathrm{CH}_{2}(\mathrm{Ph})\right), 64.90\left(\mathrm{~d}, J=6.3 \mathrm{~Hz}, \mathrm{CH}_{2}\left(\mathrm{PPh}_{3}\right)\right)$, and $54.82(\mathrm{~s}, \mathrm{OMe}) .{ }^{31} P\left\{{ }^{1} H\right\} N M R(202.46$ $\left.\mathrm{MHz}, \mathrm{CD}_{2} \mathrm{Cl}_{2}, \mathrm{RT}, \mathrm{ppm}\right): \delta=56.51(\mathrm{~s})$.

12b (34 \%). ${ }^{l} H N M R\left(500.13 \mathrm{MHz}, C D_{2} \mathrm{Cl}_{2}, R T, p p m\right): \delta=8.72(\mathrm{ddd}, J=4.7,1.6,0.8$ Hz, 1H, 6-CH(Py)), 7.80-6.57 (m, 16H, H(Ar)), 6.55 (pt, J= 7.8 Hz, 2H, H(Ar)), 6.22 (dd, $J=9.1,2.9 \mathrm{~Hz}, 1 \mathrm{H}, \mathrm{H}(\mathrm{Ar})), 6.07$ (d, $J=2.9 \mathrm{~Hz}, 1 \mathrm{H}, \mathrm{H}(\mathrm{Ar})$ ), 4.62 (d, $J=16.8 \mathrm{~Hz}$, $1 \mathrm{H}$, pro- $\left.S-\mathrm{CH}_{2}(\mathrm{Py})\right), 4.58\left(\mathrm{~d}, J=17.1 \mathrm{~Hz}, 1 \mathrm{H}\right.$, pro- $\left.R-\mathrm{CH}_{2}(\mathrm{Ph})\right), 4.11(\mathrm{dd}, J=14.3,4.4$ $\mathrm{Hz}, 1 \mathrm{H}$, pro- $\left.R-\mathrm{CH}_{2}(\mathrm{P})\right), 4.03\left(\mathrm{ddd}, J=13.0,3.3 \mathrm{~Hz}, 1 \mathrm{H}\right.$, pro- $\left.-\mathrm{C}-\mathrm{CH}_{2}(\mathrm{P})\right), 3.88(\mathrm{~d}, J=$ $16.9 \mathrm{~Hz}, 1 \mathrm{H}$, pro- $\left.R-\mathrm{CH}_{2}(\mathrm{Py})\right), 3.81$ (d, $J=17.6 \mathrm{~Hz}, 1 \mathrm{H}$, pro- $S-\mathrm{CH}_{2}(\mathrm{Ph})$ ), and 3.26 (s, $\left.3 \mathrm{H}, \mathrm{OMe}) .{ }^{13} \mathrm{C}_{\{}{ }^{1} \mathrm{H}\right\} \mathrm{NMR}\left(125.77 \mathrm{MHz}, \mathrm{CD}_{2} \mathrm{Cl}_{2}, \mathrm{RT}, \mathrm{ppm}\right): 205.51$ (d, $J=18.5 \mathrm{~Hz}$, CO), 163.95 (s, C(OMe)), 157.85 (s, 2-C(Py)), 154.25 (d, J=11.1 Hz, CRu), 152.30 (s, 6-CH(Py)), 147.55 (s, 2-C(Ph)), 142.20 (d, $J=18.7$ Hz, 2-C(PhP)), 136.79 (s, CH(Ar)), 
135.34 (s, $\mathrm{CH}(\mathrm{Ar})), 134.58$ (d, $J=10.2 \mathrm{~Hz}, 2 \mathrm{C}, \mathrm{CH}(\mathrm{Ar})), 133.37$ (d, $J=9.0 \mathrm{~Hz}, 1 \mathrm{C}$, $\mathrm{CH}(\mathrm{Ar})), 132.48$ (d, $J=9.9 \mathrm{~Hz}, 2 \mathrm{C}, \mathrm{CH}(\mathrm{Ar})), 131.05$ (d, $J=1.5 \mathrm{~Hz}, \mathrm{CH}(\mathrm{Ar})), 129.63$ (d, $J=1.8 \mathrm{~Hz}, \mathrm{CH}(\mathrm{Ar})), 128.61$ (d, $J=1.8 \mathrm{~Hz}, \mathrm{CH}(\mathrm{Ar})), 128.35$ (m, CH(Ar)), 127.56 (d, $J=10.1 \mathrm{~Hz}, 2 \mathrm{C}, \mathrm{CH}(\mathrm{Ar})), 126.86$ (d, $J=10.0 \mathrm{~Hz}, 2 \mathrm{C}, \mathrm{CH}(\mathrm{Ar})), 124.61$ (s, CH(Ar)), 123.88 (d, $J=1.5 \mathrm{~Hz}, \mathrm{CH}(\mathrm{Ar})), 123.79$ (d, $J=2.0 \mathrm{~Hz}, \mathrm{CH}(\mathrm{Ar})), 121.92$ (d, $J=3.7 \mathrm{~Hz}$, CH(Ar)), 121.43 (d, $J=1.6 \mathrm{~Hz}, \mathrm{CH}(\mathrm{Ar})$ ), 113.93 (s, CH(Ar)), 112.03 (s, CH(Ar)), 106.54 (s, $\mathrm{CH}(\mathrm{Ar})), 71.22$ (bs, $\left.\mathrm{CH}_{2}(\mathrm{Py})\right), 66.73\left(\mathrm{~s}, \mathrm{CH}_{2}(\mathrm{Ph})\right), 65.05$ (d, $J=6.2 \mathrm{~Hz}$, $\mathrm{CH}_{2}\left(\mathrm{PPh}_{3}\right)$ ), and 54.82 (s, OMe). ${ }^{31} P\left\{{ }^{l} H\right\} N M R$ (202.46 MHz, CD $\left.\mathrm{Cl}_{2}, R T, p p m\right): \delta=$ $55.71(\mathrm{~s})$.

Compound 13. Anal. calcd for $\mathrm{C}_{34} \mathrm{H}_{27} \mathrm{ClF}_{3} \mathrm{~N}_{2} \mathrm{OPRu}$ : C, 58.00; H, 3.87; N, 3.98 . Found: C, 58.30; H, 3.94; N, 3.92. IR $\left(\mathrm{cm}^{-1}\right): v(\mathrm{CO}) 1922$ (s). HRMS ( $\mu$-TOF): $\mathrm{C}_{34} \mathrm{H}_{27} \mathrm{ClF}_{3} \mathrm{~N}_{2} \mathrm{OPRu}[\mathrm{M}+\mathrm{H}]^{+}$: calc. 705.0624, found 705.0634. ${ }^{1} \mathrm{H}$ NMR (500.13 MHz, $\left.\mathrm{CD}_{2} \mathrm{Cl}_{2}, \mathrm{RT}, \mathrm{ppm}\right): \delta=8.7$ (brptd, $\left.J=5.7,2.7 \mathrm{~Hz}, 1 \mathrm{H}, 6-\mathrm{CH}(\mathrm{Py})\right), 7.7-6.3(\mathrm{~m}, 20 \mathrm{H}$, $\mathrm{H}(\mathrm{Ar})), 5.72\left(\mathrm{~d}, J=12.9 \mathrm{~Hz}, 1 \mathrm{H}\right.$, pro $\left.-R-\mathrm{CH}_{2}(\mathrm{P})\right), 5.62(\mathrm{~d}, J=14.4 \mathrm{~Hz}, 1 \mathrm{H}$, pro- $S-$ $\left.\mathrm{CH}_{2}(\mathrm{Py})\right), 4.67\left(\mathrm{~d}, J=17.0 \mathrm{~Hz}, 1 \mathrm{H}\right.$, pro- $\left.R-\mathrm{CH}_{2}(\mathrm{Ph})\right), 4.17(\mathrm{~d}, J=14.4 \mathrm{~Hz}, 1 \mathrm{H}$, pro- $R-$ $\left.\mathrm{CH}_{2}(\mathrm{Py})\right), 4.08\left(\mathrm{dd}, J=13.1,3.1 \mathrm{~Hz}, 1 \mathrm{H}, \operatorname{pro}-S-\mathrm{CH}_{2}(\mathrm{P})\right)$, and $3.90(\mathrm{~d}, J=17.1 \mathrm{~Hz}, 1 \mathrm{H}$, pro-S-CH $\left.2(\mathrm{Ph})) .{ }^{13} C_{\{}{ }^{1} H\right\} N M R\left(125.77 \mathrm{MHz}, \mathrm{CD}_{2} \mathrm{Cl}_{2}, \mathrm{RT}, \mathrm{ppm}\right): \delta=204.62(\mathrm{~d}, J=18.0$ Hz, CO), 177.23 (d, $J=10.7 \mathrm{~Hz}, \mathrm{CRu}), 157.43$ (s, 2-C(Py)), 151.52 (s, 6-CH(Py)), $146.50(\mathrm{~s}, 2-\mathrm{C}(\mathrm{Ph})), 142.00(\mathrm{~d}, J=17.6 \mathrm{~Hz}, 2-\mathrm{C}(\mathrm{PhP})), 139.30$ (s, CH(Ar)), 137.42 (s, CH(Ar)), 135.63 (s, CH(Ar)), 134.73 (d, $J=10.3 \mathrm{~Hz}, 2 \mathrm{C}, \mathrm{CH}(\mathrm{Ar})), 134.26$ (s, C(Ar)), 133.61 (d, $J=9.2 \mathrm{~Hz}, \mathrm{CH}(\mathrm{Ar})), 132.38$ (d, $J=9.6 \mathrm{~Hz}, 2 \mathrm{C}, \mathrm{CH}(\mathrm{Ar})$ ), 131.56 (s, CH(Ar)), 131.24 (s, C(Ar)), 130.04 (d, $J=2.5 \mathrm{~Hz}, \mathrm{CH}(\mathrm{Ar})), 129.12$ (d, $J=2.1 \mathrm{~Hz}$, CH(Ar)), 128.80 (s, C(Ar)), 128.54 (d, J=2.1 Hz, CH(Ar)), 127.75 (d, J=10.1 Hz, 2C, $\mathrm{CH}(\mathrm{Ar})), 127.19$ (d, $J=10.0 \mathrm{~Hz}, 2 \mathrm{C}, \mathrm{CH}(\mathrm{Ar})), 125.42$ (q, $\left.J=171.5 \mathrm{~Hz}, \mathrm{CF}_{3}\right), 124.24$ $(\mathrm{d}, J=1.70 \mathrm{~Hz}, \mathrm{CH}(\mathrm{Ar})), 122.60$ (q, $\left.J=30.9 \mathrm{~Hz}, \mathrm{C}\left(\mathrm{CF}_{3}\right)\right) 121.80$ (s, $\left.\mathrm{CH}(\mathrm{Ar})\right), 114.40$ 
(q, $J=3.6 \mathrm{~Hz}, \mathrm{CH}(\mathrm{Ar})), 71.25\left(\mathrm{~s}, \mathrm{CH}_{2}(\mathrm{Py})\right), 65.71\left(\mathrm{~s}, \mathrm{CH}_{2}(\mathrm{Ph})\right)$, and $64.87(\mathrm{~d}, J=5.2$ $\left.\mathrm{Hz}, \mathrm{CH}_{2}(\mathrm{P})\right) .{ }^{19} F\left\{{ }^{1} H\right\} N M R\left(282.33 \mathrm{MHz}, \mathrm{CD}_{2} \mathrm{Cl}, \mathrm{RT}, \mathrm{ppm}\right): \delta=-61.85$ (s). ${ }^{31} \mathrm{P}\left\{{ }^{1} \mathrm{H}\right\}$ $\operatorname{NMR}\left(202.46 \mathrm{MHz}, \mathrm{CD}_{2} \mathrm{Cl}_{2}, \mathrm{RT}\right.$, ppm): $\delta=55.12(\mathrm{~s})$.

Crystal structure determination of complexes 1, 2, 5c, 10a, 11a, 12a,b and 13a. Xray diffraction data were collected at $100(2) K$ (complexes $\mathbf{1}, \mathbf{2}, \mathbf{5 c}, \mathbf{1 0 a}, \mathbf{1 2 a}, \mathbf{b}$ and 13a) or $120(2) \mathrm{K}$ (complex 11a) using graphite-monochromated Mo Ka radiation $(\AA=$ $0.71073 \AA)$ using a narrow frame algorithm $\left(\Delta \omega=0.3^{\circ}\right)$ on a Smart APEX Bruker diffractometer. Intensities were integrated and corrected for absorption effects with $\mathrm{SAINT}^{13}$ and SADABS ${ }^{14}$ programs, integrated in APEX2 package. The structures were solved by direct methods with SHELXS-2013 or SHELXS-2017 ${ }^{15}$ and refined by fullmatrix least-squares refinements in $F^{2}$ with SHELXL-2014 or SHELXL-2017 ${ }^{16}$ programs included in WingX package. ${ }^{17}$ Most of the hydrogen atoms have been included in the model in calculated positions and refined with a riding model. Special details about the presence of solvent or disorder are listed below.

Crystal Data for 1: $\mathrm{C}_{42} \mathrm{H}_{43} \mathrm{~F}_{12} \mathrm{~N}_{2} \mathrm{PRuSb}_{2} \cdot 2\left(\mathrm{CH}_{2} \mathrm{Cl}_{2}\right) ; M=1349.17$; yellow prism, 0.220 $\times 0.250 \times 0.300 \mathrm{~mm} ;$ triclinic $P \overline{1} ; a=12.2908(5), b=13.7900(6), c=15.7626(7) \AA ; \alpha$ $=97.0026(5)^{\circ}, \beta=102.2943(5)^{\circ}, \gamma=104.4687(5)^{\circ} ; V=2483.87(18) \AA^{3} ; Z=2 ; \rho_{\text {calcd }}=$ $1.804 \mathrm{~g} \mathrm{~cm}^{-3} ; \mu=1.707 \mathrm{~cm}^{-1}$; min. and max. transmission factors 0.5963 and 0.7257 ; $2 \theta_{\max }=57.306^{\circ} ; 30558$ reflections collected; 11592 unique reflections $\left(R_{\text {int }}=0.0206\right)$; number of data/restraints/parameters: $11592 / 0 / 603$; final $G O F=1.022 ; R_{1}=0.0249$ [10410 reflections, $I>2 \sigma(I)], w R 2=0.0624$ for all data; largest difference peak: $0.894 \mathrm{e}$ $\mathrm{A}^{-3}$. A chlorine atom of the solvent has been found to be disordered. It has been included in the model in two positions with complementary occupancy factors $(0.858 / 0.142(5))$. The minor component has been isotropically refined. 
Crystal Data for $5 c$ : $\mathrm{C}_{39} \mathrm{H}_{40} \mathrm{~F}_{12} \mathrm{~N}_{5} \mathrm{OPRuSb}{ }_{2} \cdot 3 / 2\left(\mathrm{CH}_{2} \mathrm{Cl}_{2}\right) ; M=1325.69$; colorless prism, $0.130 \times 0.150 \times 0.200 \mathrm{~mm} ;$ triclinic $P \overline{1} ; a=12.1760(6), b=12.8773(6), c=16.3228(8)$ $\AA ; \alpha=81.4250(10)^{\circ}, \beta=85.5510(10)^{\circ}, \gamma=71.8340(10)^{\circ} ; V=2403.3(2) \AA^{3} ; Z=2 ; \rho_{\text {calcd }}$ $=1.832 \mathrm{~g} \mathrm{~cm}^{-3} ; \mu=1.711 \mathrm{~cm}^{-1} ;$ min. and max. transmission factors 0.7302 and 0.8227 ; $2 \theta_{\max }=57.312^{\circ} ; 28309$ reflections collected; 11215 unique reflections $\left(R_{\text {int }}=0.0302\right)$; number of data/restraints/parameters: 11215/3/601; final $G O F=1.033 ; R_{l}=0.0414$ [9271 reflections, $I>2 \sigma(I)], w R 2=0.1003$ for all data; largest difference peak: $2.336 \mathrm{e}$ $\mathrm{A}^{-3}$. The asymmetric unit contains a ruthenium complex, two $\mathrm{SbF}_{6}$ counterions and dichloromethane solvent. The counterions have been found to be in three sites, with 1 , 0.5 and 0.5 occupancy factors. The second site lies on a special position, while the third one is found to share the volume with a disordered dichloromethane (with 0.5 occupancy factor). Geometrical restraints concerning $\mathrm{C}-\mathrm{Cl}$ and $\mathrm{Sb}-\mathrm{F}$ bond lengths have been used in the refinement. At the end of the refinement, when convergence is achieved, highest residual density peaks are observed close to disordered Sb. They have no chemical sense.

Crystal Data for 10a: $\mathrm{C}_{52} \mathrm{H}_{44} \mathrm{ClF}_{3} \mathrm{~N}_{2} \mathrm{OP}_{2} \mathrm{Ru} \cdot 3\left(\mathrm{C}_{2} \mathrm{H}_{6} \mathrm{O}\right) ; M=1106.55$; colorless prism, $0.100 \times 0.115 \times 0.130 \mathrm{~mm} ;$ triclinic $P \overline{1} ; a=13.1863(11), b=14.5593(12), c=$ $15.1056(13) \AA ; \alpha=99.1230(10)^{\circ}, \beta=104.1100(10)^{\circ}, \gamma=103.1760(10)^{\circ} ; V=2667.2(4)$ $\AA^{3} ; Z=2 ; \rho_{\text {calcd }}=1.378 \mathrm{~g} \mathrm{~cm}^{-3} ; \mu=0.462 \mathrm{~cm}^{-1}$; min. and max. transmission factors 0.8062 and $0.9705 ; 2 \theta_{\max }=56.664^{\circ} ; 31264$ reflections collected; 12697 unique reflections $\left(R_{\text {int }}=0.0463\right)$; number of data/restraints/parameters: $12697 / 2 / 664$; final $G O F=1.060 ; R_{1}=0.0561[10206$ reflections, $I>2 \sigma(I)], w R 2=0.1297$ for all data; largest difference peak: $1.241 \mathrm{e} \mathrm{A}^{-3}$. Two of the three independent solvent molecules have been found to be disordered. Their disordered fragments (methyl or hydroxyl group) have been included in the model in two sets of positions and isotropically 
refined. Hydrido ligand and hydrogen atoms of $\mathrm{OH}$ groups of solvent molecules involved in hydrogen bonds have been included in the model in observed positions and freely refined.

Crystal Data for 11a: $\mathrm{C}_{33} \mathrm{H}_{28} \mathrm{ClN}_{2} \mathrm{OPRu} \cdot \mathrm{CH}_{2} \mathrm{Cl}_{2} ; M=720.99$; yellow plate, $0.075 \times$ $0.175 \times 0.200 \mathrm{~mm} ;$ monoclinic $P 2_{1} / c ; a=16.6067(8), b=9.8577(5), c=19.3399(9) \AA ;$ $\beta=102.7540(10)^{\circ} ; V=3087.9(4) \AA^{3} ; \mathrm{T}=120(2) \mathrm{K} ; Z=4 ; \rho_{\text {calcd }}=1.551 \mathrm{~g} \mathrm{~cm}^{-3} ; \mu=$ $0.850 \mathrm{~cm}^{-1}$; min. and max. transmission factors 0.7982 and $0.9044 ; 2 \theta_{\max }=54.864^{\circ}$; 42123 reflections collected; 7022 unique reflections $\left(R_{\text {int }}=0.0416\right)$; number of data/restraints/parameters: $7022 / 0 / 378 ;$ final $G O F=1.051 ; R_{1}=0.0418[6016$ reflections, $I>2 \sigma(I)], w R 2=0.1166$ for all data; largest difference peak: $0.923 \mathrm{e} \mathrm{A}^{-3}$. A carbon and a chlorine atom of dichloromethane solvent have been found to be disordered. They have been included in the model in two sets of positions and isotropically refined with complementary occupancy factors $(0.585 / 0.415(8))$.

Crystal Data for 12a,b: $\mathrm{C}_{34} \mathrm{H}_{30} \mathrm{ClN}_{2} \mathrm{O}_{2} \mathrm{PRu} \cdot \mathrm{H}_{2} \mathrm{O} ; M=684.10$; yellow plate, $0.080 \times$ $0.150 \times 0.230 \mathrm{~mm} ;$ monoclinic $C 2 / c ; a=19.1243(17), b=11.2815(10), c=28.078(3)$ $\AA ; \beta=101.4340(10)^{\circ} ; V=5937.7(9) \AA^{3} ; \mathrm{T}=100(2) \mathrm{K} ; Z=8 ; \rho_{\text {calcd }}=1.531 \mathrm{~g} \mathrm{~cm}^{-3} ; \mu=$ $0.711 \mathrm{~cm}^{-1}$; min. and max. transmission factors 0.6830 and $0.7457 ; 2 \theta_{\max }=56.608^{\circ}$; 33705 reflections collected; 7225 unique reflections $\left(R_{\text {int }}=0.0779\right)$; number of data/restraints/parameters: $7225 / 0 / 372 ;$ final $G O F=1.041 ; R_{1}=0.0584[4935$ reflections, $I>2 \sigma(I)], w R 2=0.1470$ for all data; largest difference peak: $0.916 \mathrm{e} \mathrm{A}^{-3}$.

Part of a phenyl group, the methoxo fragment and solvent water have been found to be disordered. They have been included in the model in two sets of positions and refined with complementary occupancy factors. A common value has been used to isotropically refine minor and major components of carbon and oxygen atoms. 
Crystal Data for 13a: $\mathrm{C}_{34} \mathrm{H}_{27} \mathrm{ClF}_{3} \mathrm{~N}_{2} \mathrm{OPRu} \cdot \mathrm{CH}_{2} \mathrm{Cl}_{2} ; M=788.99$; yellow prism, $0.100 \times$ $0.110 \times 0.150 \mathrm{~mm} ;$ monoclinic $P 2{ }_{1} / n ; a=12.6163(8), b=10.4172(6), c=24.8162(15)$ $\AA ; \beta=93.6150(10)^{\circ} ; V=3255.0(3) \AA^{3} ; Z=4 ; \rho_{\text {calcd }}=1.610 \mathrm{~g} \mathrm{~cm}^{-3} ; \mu=0.827 \mathrm{~cm}^{-1}$; min. and max. transmission factors 0.8421 and $0.9281 ; 2 \theta_{\max }=56.634^{\circ} ; 41602$ reflections collected; 7975 unique reflections $\left(R_{\text {int }}=0.0519\right)$; number of data/restraints/parameters: 7975/0/414; final $G O F=1.060 ; \quad R_{l}=0.0675[6547$ reflections, $I>2 \sigma(I)], w R 2=0.1742$ for all data; largest difference peak: 1.779 e $\mathrm{A}^{-3}$. One of the chlorine atoms of dichloromethane solvent has been found to be disordered and isotropically refined with complementary occupancy factors $(0.754 / 0.246(5))$ in two positions. 


\section{ASSOCIATED CONTENT}

Supporting Information Available: Kinetic studies for the isomerization of complex 10. Selected NMR spectra of compounds 11-13. Crystal structure determination of complex 2. Intermolecular interactions details of complex 5c. Ring puckering parameters for complexes 1, 2, 5c, 10a, 11a, 12a,b and 13a. CCDC 1829050-1829056 contains the supplementary crystallographic data for this paper $(\mathbf{1}, \mathbf{2}, \mathbf{5 c}, \mathbf{1 0 a}, \mathbf{1 1 a}$, 12a,b, 13a complexes in CIF format). These data can be obtained free of charge from the Cambridge Crystallographic Data Centre. This material is available free of charge via the Internet at http://pubs.acs.org.

\section{AUTHOR INFORMATION}

\section{Corresponding Author}

* E-mail: dcarmona@unizar.es (D. C.); riromar@unizar.es (R. R.); fviguri@unizar.es (F. V.)

Tel: 34-976-762027. Fax: 34-976-761187

\section{ORCID}

Isabel Méndez: 0000-0002-0116-9743

Fernando Viguri: 0000-0002-6160-3046

Ricardo Rodríguez: 0000-0002-8845-0174

Fernando J. Lahoz: 0000-0001-8054-2237

Pilar García-Orduña: 0000-0002-7063-1292

Daniel Carmona: 0000-0003-4196-5856 


\section{Notes}

The authors declare no competing financial interest.

\section{ACKNOWLEDGMENTS}

We thank the Ministerio de Economía y Competitividad of Spain (Project CTQ201566079-P) and Gobierno de Aragón (Grupo Consolidado: Catalizadores Organometálicos Enantioselectivos) for financial support. R. R. acknowledges the Ministerio de Economía y Competitividad of Spain for a Ramón y Cajal (RYC-2013-13800) grant. P. G. O. acknowledges CSIC and European Social Fund for a PTA contract. Dedicated to Professor Ernesto Carmona on the occasion of his $70^{\text {th }}$ birthday. 


\section{REFERENCES AND NOTES}

[1] (a) Comprehensive Asymmetric Catalysis; Jacobsen, E. N.; Pfaltz, A.; Yamamoto, H., Eds.; Vol I-III, Springer: New York, 1999; Suppl. 1 and 2, Springer: New York, 2004. (b) Catalytic Asymmetric Synthesis, Ojima, I., Ed.; Wiley-VCH: Weinheim, 2000. (c) Noyori, R. In Asymmetric Catalysis in Organic Synthesis, Wiley: Hoboken, 1994. (d) Walsh, P. J.; Kozlowski, M. C. In Fundamentals of Asymmetric Catalysis, University Science Books: Sausalito, 2009. (e) Lewis Acids in Organic Synthesis, Yamamoto H. Ed., Wiley-VCH: Weinheim, 2000. (f) Transition Metals for Organic Synthesis: Building Blocks and Fine Chemicals, $2^{\text {nd }}$ Edition, Beller, M.; Bolm, C., Eds.; Wiley-VCH: Weinheim, 2008.

[2] (a) Zhang, L.; Meggers, E. Steering Asymmetric Lewis Acid Catalysis Exclusively with Octahedral Metal-Centered Chirality. Acc. Chem. Res. 2017, 50, 320-330. (b) Fontecave, M.; Hamelin, O.; Ménage, S. Chiral-at-Metal Complexes as Asymmetric Catalysts. Top. Organomet. Chem. 2005, 15, 271-288. (c) Brunner, H. Optically Active Organometallic Compounds of Transition Elements with Chiral Metal Atoms. Angew. Chem. Int. Ed. 1999, 38, 1194-1208.

[3] (a) Zheng, Y.; Tan, Y.; Harms, K.; Marsch, M.; Riedel, R.; Zhang, L.; Meggers, E. Octahedral Ruthenium Complex with Exclusive Metal-Centered Chirality for Highly Effective Asymmetric Catalysis. J. Am. Chem. Soc. 2017, 139, 43224325. (b) Meggers, E. Exploiting Octahedral Stereocenters: From Enzyme Inhibition to Asymmetric Photoredox Catalysis. Angew. Chem. Int. Ed. 2017, 56, 5668-5675. (c) Zhang, L.; Meggers, E. Stereogenic-Only-at-Metal Asymmetric Catalysts. Chem. Asian J. 2017, 12, 2335-2342. (d) Cao, Z.-Y.; Brittain, W. D. G.; Fossey, J. S.; Zhou, F. Recent advances in the use of chiral metal complexes 
with achiral ligands for application in asymmetric catalysis. Catal. Sci. Technol. 2015, 5, 3441-3451. (e) Gong. L.; Chen, L.-A.; Meggers, E. Asymmetric Catalysis Mediated by the Ligand Sphere of Octahedral Chiral-at-Metal Complexes. Angew. Chem. Int. Ed. 2014, 53, 10868-10874. (f) Huo, H.; Shen, X.; Wang, C.; Zhang, L.; Röse, P.; Chen, L.-A.; Harms, K.; Marsch, M.; Hilt, G.; Meggers, E. Asymmetric photoredox transition-metal catalysis activated by visible light. Nature 2014, 515, 100-103.

[4] (a) Carmona, M.; Rodríguez, R.; Méndez, I.; Passarelli, V.; Lahoz, F. J.; GarcíaOrduña, P.; Carmona, D. Stereospecific control of the metal-centred chirality of rhodium(III) and iridium(III) complexes bearing tetradentate CNN'P ligands. Dalton Trans. 2017, 46, 7332-7350. (b) Carmona, M; Tejedor, L.; Rodríguez, R.; Passarelli, V.; Lahoz. F. J.; García-Orduña, P.; Carmona, D. The Stepwise Reaction of Rhodium and Iridium Complexes of Formula $\left[\mathrm{MCl}_{2}\left(\mathrm{k}^{4} C, N, N, P-\mathbf{L}\right)\right]$ with Silver Cations: A Case of trans-Influence and Chiral Self-Recognition. Chem. Eur. J. 2017, 23, 14532-14546.

[5] (a) Knof, U.; von Zelewsky, A. Predetermined Chirality at Metal Centers. Angew. Chem. Int. Ed. 1999, 38, 302-322. (b) Knight, P. D.; Scott, P. Predetermination of chirality at octahedral centres with tetradentate ligands: prospects for enantioselective catalysis. Coord. Chem. Rev. 2003, 242, 125-143. (c) Meggers, E. Asymmetric Synthesis of Octahedral Coordination Complexes. Eric Meggers Eur. J. Inorg. Chem. 2011, 2911-2926.

[6] Carmona, M.; Rodríguez, R.; Passarelli, V.; Lahoz, F. J.; García-Orduña, P.; Carmona, D. Metal as Source of Chirality in Octahedral Complexes with Tripodal Tetradentate Ligands. J. Am. Chem. Soc. 2018, 140, 912-915. 
[7] Bennet, M. A.; Huang, T. N.; Matheson, T. W.; Smith, A. K. $\left(\eta^{6}-\right.$ Hexamethylbenzene)Ruthenium Complexes. Inorg. Synth. 1982, 21, 75.

[8] Hallman, P. S.; Stephenson, T. A.; Wilkinson, G. Tetrakis(triphenylphosphine) dichlororuthenium(II) and Tris(triphenylphosphine)dichlororuthenium(II). Inorg. Synth. 1970, 12, 237-238.

[9] Ahmad, N.; Levison, J. J.; Robinson, S. D.; Uttley, M. F. Complexes of Ruthenium, Osmium, Rhodium, and Iridium Containing Hydride Carbonyl, or Nitrosyl Ligands. Inorg. Synth. 1974, 15, 48.

[10] (a) Cahn, R. S.; Ingold, C.; Prelog, V. Specification of Molecular Chirality. Angew. Chem., Int. Ed. Engl. 1966, 5, 385-415. (b) Prelog, V.; Helmchen, G. Basic Principles of the CIP-System and Proposals for a Revision. Angew. Chem., Int. Ed. Engl. 1982, 21, 567-583. (c) Lecomte, C.; Dusausoy, Y.; Protas, J.; Tirouflet, J. Dormond, A. Structure crystalline et configuration relative d'un complexe du titanocene presentant une chiralite plane et une chiralite centree sur l'atome de titane. J. Organomet. Chem. 1974, 73, 67-76.

[11] For the $C / A$ convention for octahedral centers see: (d) Connelly, N. G.; Damhus, T.; Hartshorn R. H.; Hutton A. T. In Nomenclature of Inorganic Chemistry; IUPAC Recommendations 2005, RSC Publishing, Cambridge, UK. Chapter IR9.3.4.8, p. 189.

[12] Groom, C. R.; Bruno, I. J.; Lightfoot, M. P.; Ward, S. C. The Cambridge Structural Database. Acta Crystallogr. 2016, B72, 171-179.

[13] SAINT+, version 6.01: Area-Detector Integration Software, Bruker AXS, Madison, WI, 2001. 
[14] (a) Blessing, R. H. An empirical correction for absorption anisotropy. Acta Crystallogr. 1995, A51, 33-38. (b) SADABS, Area Detector Absorption Program. Bruker AXS, Madison, WI, 1996.

[15] Sheldrick, G. M. A short history of SHELX. Acta Crystallogr. 2008, A64, 112122.

[16] Sheldrick, G. M. Crystal structure refinement with SHELXL Acta Crystallogr. 2015, $C 71,3-8$.

[17] Farrugia L. J. WinGX and ORTEP for Windows: an update. J. Appl. Cryst. 2012, 45, 849-854. 